Department of Internal Medicine I

University Medical Center Ulm

Prof. Dr. Thomas Seufferlein

\title{
Loss of Keratin 19 predisposes to \\ the development of cholestatic liver disease
}

\author{
Dissertation presented to the Medical Faculty of Ulm University \\ to obtain the degree Doctor of Human Biology
}

Yu Chen

From Jinan, China

2014 
Current Dean: Prof. Dr. Thomas Wirth

Thesis reviewers:

1 $_{\mathrm{st}}$ reviewer: PD Dr. Pavel Strnad

$2_{\text {nd }}$ reviewer: Prof. Dr. Paul Walther

Date of doctorate awarded: 28.07 .2014 


\section{Table of Content}

Abbreviations..................................................................................

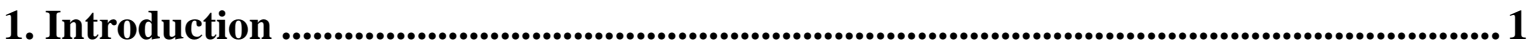

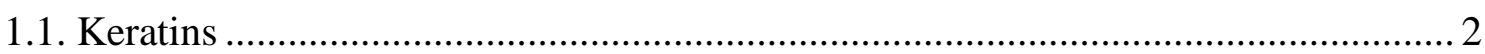

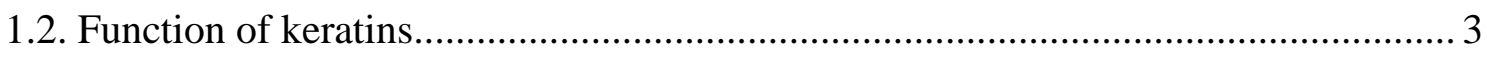

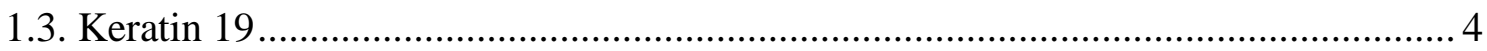

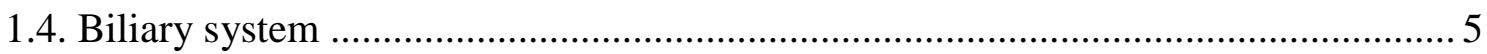

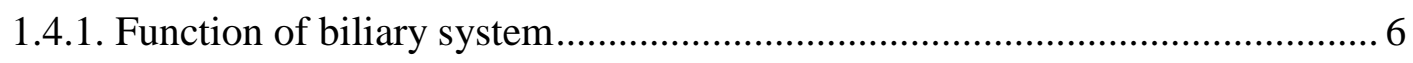

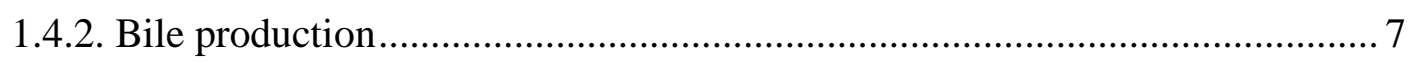

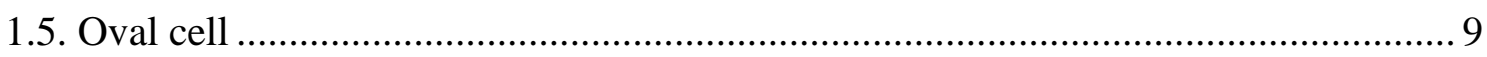

1.5.1. Oval cells are K19-positive liver progenitor cells (LPCs) ........................... 9

1.5.2. Diverse signaling pathways during oval cell differentiation...................... 10

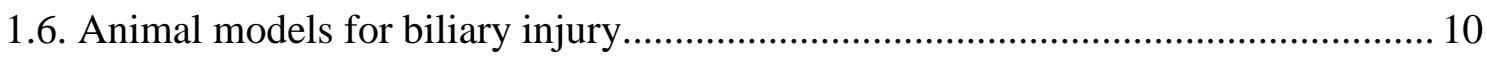

1.6.1. Chronic feeding with 3,5-diethoxycarbonyl-1,4-dihydrocollidine (DDC) .. 11

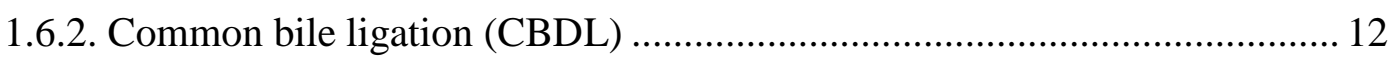

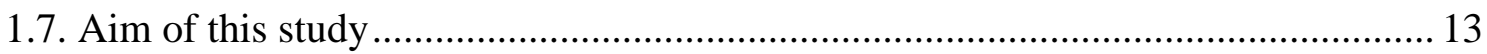

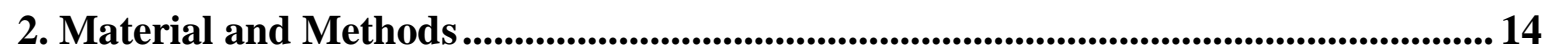

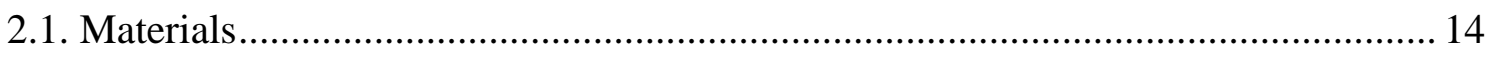

2.1.1. General equipment and consumables................................................. 14

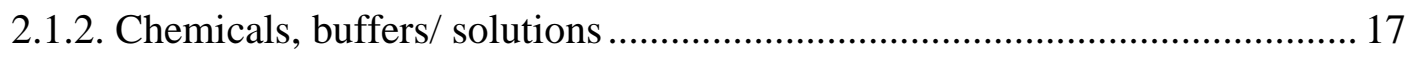

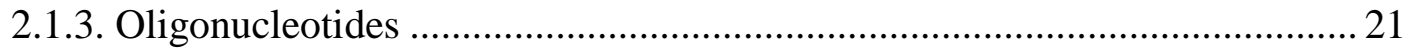

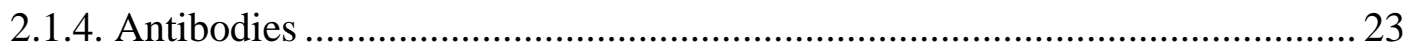


2.1.5. Mice 24

2.2. Methods 25

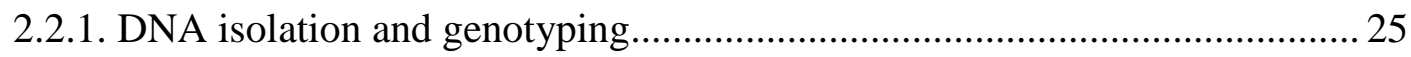

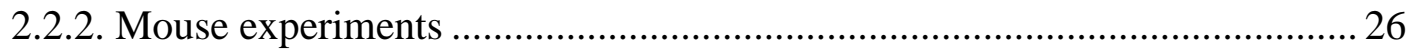

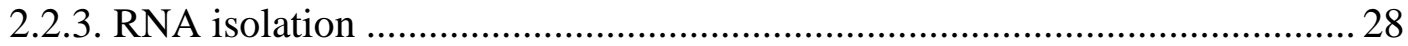

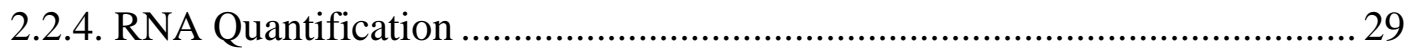

2.2.5. Reverse Transcription and cDNA translation ............................................ 29

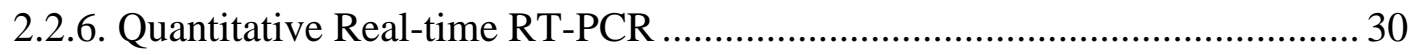

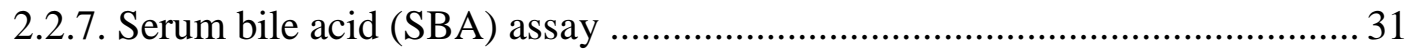

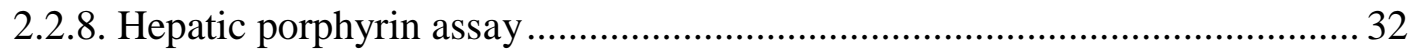

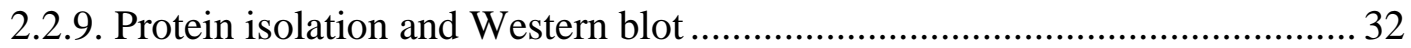

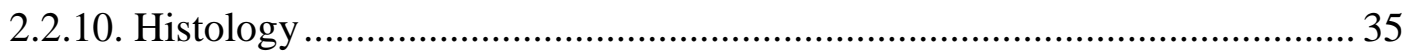

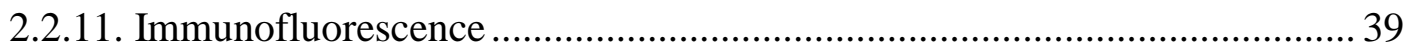

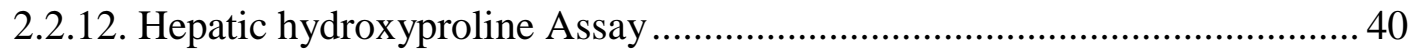

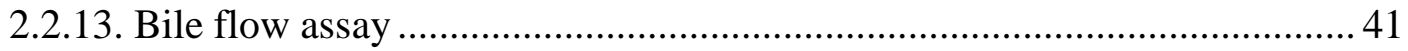

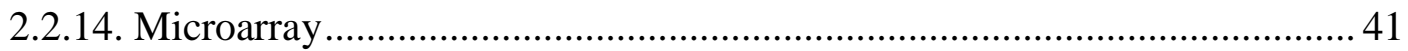

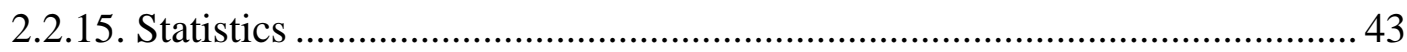

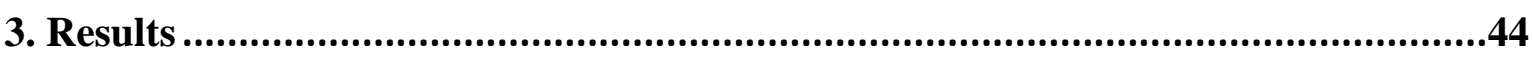

3.1. Characterization of role of Keratin 19 (K19) under basal conditions ..................... 44

3.1.1. Confirmation of genotyping at protein level ............................................. 44

3.1.2. Analysis of keratin gene expression in digestive system of K19-KO and -WT mice.. .45

3.1.3. K19 loss leads to alteration of keratin distribution 45 
3.1.4. K19-KO mice display largely normal biliary function under basal

condition

3.2. K19-KO mice suffer more severe biliary injury after chronic DDC

administration. 48

3.2.1. Loss of K19 causes stronger cholestatic liver injury after 4-week DDC feeding.

3.2.2. Loss of K19 results in a higher extent of biliary obstruction after 4-week

DDC feeding

3.2.3. Loss of K19 results in decreased biliary bicarbonate levels after chronic DDC treatment .51

3.2.4. Loss of K19 leads to altered gene expression after 4-week DDC feeding....51

3.3. DDC-fed K19-KO mice display weaker ductular reaction and biliary fibrosis ...... 53

3.3.1. Loss of K19 reduces biliary regeneration after 4-week DDC treatment........ 53

3.3.2. Loss of K19 reduces DDC-induced proliferation of cholangiocytes ............. 55

3.3.3. DDC-induced oval cell activation is attenuated in K19-KOs .........................57

3.3.4. DDC-induced Notch2 signaling is impaired in K19-KOs ............................. 58

3.3.5. K19 deletion attenuates DDC-induced biliary fibrosis ................................5 59

3.4. Loss of K19 does not affect bile duct obstruction- related injury ........................... 62

4. Discussion 68

4.1. Loss of K19 is well-compensated under physiological conditions 68

4.2. Loss of K19 results in a susceptibility to DDC-induced cholestatic liver injury..... 69

4.2.1. K19-KO mice suffer a more severe DDC-induced biliary injury

4.2.2. Decreased DDC-induced ductular reaction and LPC proliferation in K19-KO livers is due to impaired Notch2 signaling.... .71 
4.2.3. Ameliorated DDC-induced biliary fibrosis in K19-KO livers may be due to inhibited LPC proliferation

4.3. Loss of K19 does not affect the development of cholestatic liver injury induced by

CBDL

5. Summary

6. References.

7. Appendix

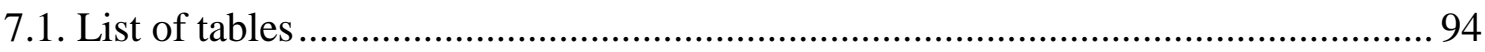

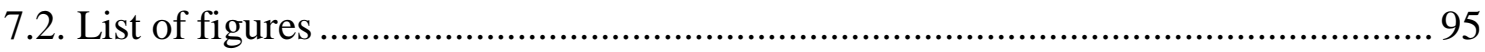

8. Acknowledgements 


\section{Abbreviations}

3- $\alpha$ HSD

aa

$\mathrm{ABC}$

$\mathrm{ABCB}$

$\mathrm{ABCC}$

ABCG

ADP

AE

AGS

$\mathrm{AH}$

AL

ALP

ALT

APS

AQP

ASBT

AST

BEC

Bili tot

bp

BrdU

BSA

BSEP

C

CA

CBD

CBDL

$\mathrm{CCl}_{4}$

CDE

cDNA

CFTR
3- $\alpha$ hydroxysteroid dehydrogenase

amino acid

Avidin/Biotinylated enzyme Complex

ATP-binding cassette, subfamily B member

ATP-binding cassette, subfamily $\mathrm{C}$ member

ATP-binding cassette, subfamily $\mathrm{G}$ member

atypical ductular proliferation

anion exchange protein

Alagille syndrome

acute hepatitis

apicolateral

alkaline phosphatase

alanine aminotransferase

ammonium persulfate

aquaporin

apical sodium dependent bile acid transporter

aspartate aminotransferase

biliary epithelial cell

total bilirubin

base pairs

5-bromo-2-deoxyuridine

serum albumin

bile salt export pump

cytoplasmic

cholic acid

common bile duct

common bile duct ligation

carbon tetrachloride

choline-deficient, ethionine-supplemented

complementary DNA

cystic fibrosis transmembrane conductance regulator 
CNS

$\mathrm{CO}_{2}$

Colla1

$\mathrm{C}_{\mathrm{q}}$

CTL

$\mathrm{Da}$

DDC

DEPC

DNA

dNTP

ECL

ECM

EDTA

EpCAM

et al.

$\gamma$-GT

GB

GFAP

$\mathrm{h}$

$\mathrm{HCl}$

HBX

$\mathrm{HCC}$

$\mathrm{H} \& \mathrm{E}$

HGF

$\mathrm{H}_{2} \mathrm{O}_{2}$

HRP

HSC

HSE

IF

IF

IHBD

IHC

IL-6 central nervous system

carbon dioxide

alpha-1 type 1 collagen

quantification cycle

control

Dalton (unit of molecular weight)

3,5-diethoxycarbonyl-1,4-dihydrocollidine

diethylpyrocarbonate

desoxyribonucleic acid

deoxynucleotide

enhanced chemiluminescence

extracellular matrix

ethylenediaminetetraacetic acid

epithelial cell adhesion molecule

et alii (and others)

$\gamma$-glutamyl transpeptidase

gall bladder

Glial fibrillary acidic protein

hour

hydrogen chloride

hepatitis B virus $\mathrm{X}$

hepatocellular carcinoma

haematoxylin and eosin

hepatocyte growth factor

hydrogen peroxide

horseradish peroxidase

hepatic stellate cells

high salt extraction

immunofluorescence

intermediate filaments

intrahepatic bile duct

immunohistochemistry

interleukin 6 
K

KO

LPC

$\mu$

$\mathrm{m}$

MDR

$\mathrm{MgCl}_{2}$

mRNA

MRP

n

$\mathrm{NaCl}$

$\mathrm{NAD}^{+}$

NAFLD

NBC

NBT

NDCBE

NF

NHE

NTCP

OATP

OC

OST

panK

PBC

PBS

PCR

pI

PMSF

PNS

PPIX

PSC

PSR

PVDF keratin

knockout

liver progenitor cell

mikro

milli

multidrug resistance protein

magnesium chloride

messenger RNA

multidrug resistance-associated protein

nano

natrium chloride

nicotinamide adenine dinucleotide

nonalcoholic fatty liver disease

sodium bicarbonate cotransporter

nitrotetrazolium blue

$\mathrm{Na}^{+}$-driven $\mathrm{Cl}^{-} / \mathrm{HCO}^{-}$exchanger

neurofilament

sodium-hydrogen exchanger

$\mathrm{Na}^{+}$-taurocholate cotransporting polypeptide

organic anion-transporting polypeptide

oval cell

organic solute transporter

pankeratin

primary biliary cirrhosis

phosphate buffered saline

Polymerase chain reaction

isoelectric point

phenylmethanesulfonyl fluoride

peripheral nervous system

protoporphyrin IX

primary sclerosing cholangitis

picro-sirius red

polyvinylidene fluoride 
RMA

RNA

RT

SBA

SDS-PAGE

SEM

SLC

SSTR2

TAA

TEMED

TGF

TWEAK

UV

WB

WT robust multiarray average

ribonucleic acid

Reverse Transcription PCR

serum bile acid

Sodium dodecyl sulphate polyacrylamide gel electrophoresis

standard error of the mean

solute carrier family

somatostatin receptor type 2

thiacetamide

tetramethylethylenediamine

transforming growth factor

TNF-like weak inducer of apoptosis

ultraviolet

western blot

wild type 


\section{Introduction}

Intermediate filaments (IFs) represent one of the three major filamentous systems of the cell and function as cytoskeletal scaffolds in the nucleus and cytoplasm [1-3]. IF proteins are divided into five subgroups (Table 1): Four of them are localized in the cytoplasm (Type I-IV) and one in the nucleus (Type V- lamins) [4-5]. Specifically, keratins constitute type I and type II IF proteins, building obligatory type I- type II heteropolymers in epithelial cells [6-7].

Table 1. Classification and localization of intermediate filament (IF) proteins

\begin{tabular}{|c|c|c|c|}
\hline Type & Name & \multicolumn{2}{|c|}{ Localization } \\
\hline Type I & Acidic keratins & \multirow{2}{*}{\multicolumn{2}{|c|}{ epithelia }} \\
\hline Type II & Basic keratins & & \\
\hline \multirow{4}{*}{ Type III } & Vimentin & \multicolumn{2}{|c|}{$\begin{array}{c}\text { Mesenchymal cells } \\
\text { (e.g. fibroblast, endothelium, leukocytes) }\end{array}$} \\
\hline & Desmin & \multicolumn{2}{|c|}{ Muscle cells } \\
\hline & Glial fibrillary acidic protein (GFAP) & \multicolumn{2}{|c|}{$\begin{array}{l}\text { Astrocytes, glial cells, } \\
\text { Hepatic stellate cells }\end{array}$} \\
\hline & Peripherin & \multicolumn{2}{|c|}{ Peripheral nervous system (PNS) neurons } \\
\hline \multirow{4}{*}{ Type IV } & $\begin{array}{c}\text { Neurofilament subunits: } \\
\text { NF-L (low), } \\
\text { NF-M (medium), } \\
\text { NF-H (high) }\end{array}$ & \multicolumn{2}{|c|}{ Central nervous system (CNS) neurons } \\
\hline & $\alpha$ - internexin & \multicolumn{2}{|c|}{ CNS neurons } \\
\hline & Nestin & \multicolumn{2}{|c|}{$\begin{array}{l}\text { Neuroepithelial stem cells, } \\
\text { muscle cells }\end{array}$} \\
\hline & Desmuslin & \multicolumn{2}{|c|}{ Muscle } \\
\hline \multirow[b]{2}{*}{ Type V } & A-type lamins (Lamins A and C) & \multirow[b]{2}{*}{ nucleus } & Differentiated cells \\
\hline & B-type lamins (Lamins B1 and B2) & & Ubiquitous \\
\hline
\end{tabular}

Table 1 adapted from [4-5]. 


\subsection{Keratins}

Keratins (Ks) share the common secondary structure with other IF proteins consisting of $\mathrm{N}$-terminal head domain, central $\alpha$-helical rod domain and C-terminal tail domain [8-9]. According to their isoelectric point (pI), keratins can be categorized into acidic type I keratins (pI ranging from 4.9 to 5.4) and basic type II keratins ( $\mathrm{pI}$ of 6.5-8.5), and so far 28 type I and 26 type II keratins have been identified in humans [10-12]. In human genome, the keratin genes are localized at two different chromosomal sites: chromosome 17q21.2 (type I keratins except K18) and chromosome 12q13.13 (type II keratins and K18) [12]. Keratins are epithelial-specific IF proteins, that are distributed in a tissue-specific manner (Table 2) [6-7, 13].

Table 2. Distributions of keratins in epithelial tissues

\begin{tabular}{|c|c|}
\hline Tissue & $\underline{\text { Keratin (K) }}$ \\
\hline Bile duct & $\mathrm{K} 7, \mathrm{~K} 8, \mathrm{~K} 18, \mathrm{~K} 19$ \\
\hline Gallbladder & $\mathrm{K} 7, \mathrm{~K} 8, \mathrm{~K} 18, \mathrm{~K} 19, \mathrm{~K} 20$ \\
\hline Adult Hepatocyte & $\mathrm{K} 7, \mathrm{~K} 8, \mathrm{~K} 18, \mathrm{~K} 19$ \\
\hline Ductal pancreas & $\mathrm{K} 8, \mathrm{~K} 18, \mathrm{~K} 19$ \\
\hline Pancreas acinar cell & $\mathrm{K} 7, \mathrm{~K} 8, \mathrm{~K} 18, \mathrm{~K} 18, \mathrm{~K} 19, \mathrm{~K} 20$ \\
\hline Colon & $\mathrm{K} 7, \mathrm{~K} 8, \mathrm{~K} 18, \mathrm{~K} 19, \mathrm{~K} 20$ \\
\hline Small intestine & $\mathrm{K} 7, \mathrm{~K} 8, \mathrm{~K} 18, \mathrm{~K} 19$ \\
\hline Stomach & $\mathrm{K} 3, \mathrm{~K} 12$ \\
\hline Kidney & \\
\hline Corneal epithelium & \\
\hline
\end{tabular}

Table 2 adapted from [13-15].

Biochemically, keratins are resistant to proteases and because of their marked insolubility can be isolated in solutions containing strong denaturing reagents such as $8 \mathrm{M}$ urea [16], or with the well-established high salt extraction (HSE) method that is used to obtain keratin enriched fractions [17]. On the other hand, keratins are capable of spontaneously reassembling into dimers/polymers in aqueous solution or even low molar urea [18-19]. 


\subsection{Function of keratins}

The understanding of the physiological significance of keratins is growing due to a large number of human diseases that are linked to keratin mutations (Table 3) [13, 20]. Moreover, investigations from keratin-knockout (KO) and other keratin-deficient transgenic mice models [21-30] demonstrate that keratins play important roles in the maintenance of cellular homeostasis.

Table 3. Representative human disorders related with keratin mutations

\begin{tabular}{|c|c|}
\hline Diseases & $\underline{\text { Keratin }(\mathbf{K})}$ \\
\hline Epidermolysis bullosa simplex & $\mathrm{K} 5, \mathrm{~K} 14$ \\
\hline Monilethrix & $\mathrm{K} 81, \mathrm{~K} 83, \mathrm{~K} 86$ \\
\hline Ectodermal dysplasia of hair and nail type & $\mathrm{K} 85$ \\
\hline Meesmann corneal epithelial dystrophy & $\mathrm{K} 8, \mathrm{~K} 18$ \\
\hline Inflammatory bowel disease & $\mathrm{K} 8, \mathrm{~K} 18$ \\
\hline Familial cirrhosis & $\mathrm{K} 4, \mathrm{~K} 13$ \\
\hline White sponge nevus & $\mathrm{K} 2$ \\
\hline Ichthyosis bullosa of Siemens & $\mathrm{K} 75$ \\
\hline Pseudofolliculitis barbae & $\mathrm{K} 5$ \\
\hline Dowling-Degos disease & $\mathrm{K} 1$ \\
\hline Epidermolytic palmoplantar keratoderma & $\mathrm{K} 9$ \\
\hline
\end{tabular}

Table 3 adapted from [31-32].

Keratins serve as a cytoprotective cytoskeletal scaffold maintaining the structural integrity and providing support against mechanical stress [33-35]. Furthermore, keratins mediate/facilitate various non-mechanical biological functions such as 1) regulation of protein targeting and cellular transport in epithelial cells [36-37]; 2) establishment of cellular polarity [38]; 3) cell metabolic processes by modulating protein synthesis and cell growth [39]; 4) defense against apoptosis [40-41]. 


\subsection{Keratin 19}

$\mathrm{K} 19$ is a type I keratin with a molecular weight of $40 \mathrm{kDa}$ and $\mathrm{pI}$ of 5.2, that forms intermediate filaments with type II keratins (preferentially interacts with $\mathrm{K} 7$ to form heterodimers) [10, 42-43]. Notably, K19 has a very short the tail domains and constitutes the smallest known type I polypeptide [42].

Ductal epithelia (e.g. the lining of gastroenteropancreatic and hepatobiliary tracts) are among tissues with the highest K19 expression (Table 2) [10, 44-45]. Of note, K19 expression is restricted to the biliary system in adult liver under physiological condition, and therefore, K19 represents as an established marker for cholangiocytes [46]. Besides, K19 is the established stem cell marker and the double labeling of K19 and 5-bromo-2deoxyuridine (BrdU) has been applied in the identification of epithelial stem cells [47]. In liver K19 is also expressed in liver progenitor cells (LPCs), which are activated during liver regeneration process as in response to liver damage [48-50]. For example, recent study showed that loss of canal of Hering marked with K19 staining appeared in the early stage of primary biliary cirrhosis (PBC), and this finding may provide support to clinical diagnosis of PBC [51]. Further, K19 is also often expressed in a variety of human cancers, such as urothelial bladder carcinoma, advanced thyroid cancer and hepatocellular carcinoma (HCC) [10, 44-45, 52]. Specifically, in the subtype of HCC which characterized with expression of K19, it is histologically poorly differentiated and exhibit aggressive tumour activity. The cultured K19-positive HCC cells still exhibited high invasive potential in vitro [53-54]. Because of that, K19 serves as an important serum tumor marker as well as a pathological adjunct in diagnostics of carcinoma of unknown primary $[13,44-$ 45].

In order to investigate the biological function of K19 in vivo, K19-KO mice were generated [55]. Previous report demonstrated that K19 are largely dispensable under basal conditions, since K19-KO mice are viable, fertile, and phenotypically largely normal, and loss of K19 only leads to mild muscular phenotype [56]. As mentioned above in Table 3, recent publication identified K19 G17S variant in patients with PBC [57], indicating that mutations in K19 may predispose to development of cholestatic liver disorders. Given that 
K19 is highly expressed in ductal epithelia, I analyzed the function of K19 in my PhD thesis.

\subsection{Biliary system}

The three-dimensional tree-like structure of biliary system is lined by cholangiocytes (approximately $5 \%$ of cells in liver), which function as ductal bile modifier during transport to the duodenum and facilitate the detoxification of xenobiotics in daily metabolism [58-59]. The complex network of biliary system begins with the canal of Hering, a channel connecting the hepatocellular sinusoid with the smallest ducts, which is composed of cholangiocytes, hepatocytes and also bipotential hepatic progenitor cells [6061]. Intrahepatic bile ducts converge to form extrahepatic bile ducts (Figure 1). With the progressive enlargement of the ductal system, cholangiocytes become larger in size and more columnar in shape [60, 62-63].

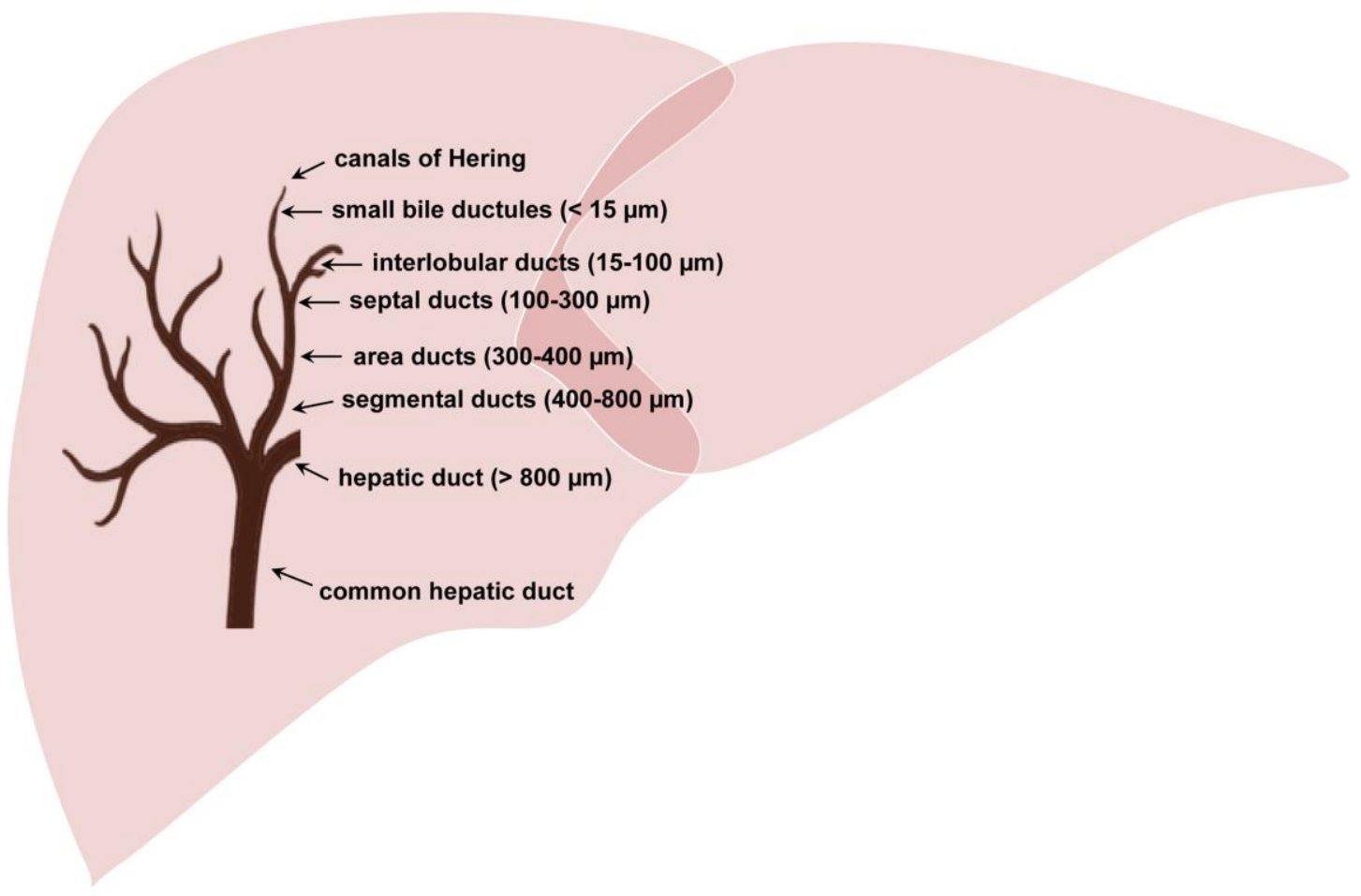

Figure 1. Schematic morphology of biliary structures. The biliary system is made of ductal structures extending from the canals of Hering up to the extrahepatic bile ducts, thereby connecting hepatocellular sinusoids with small intestines. Scheme according to Tabibian JH et al. with minor changes [63]. 
As mentioned above, large and small intrahepatic bile ducts are composed of large and small cholangiocytes, respectively. Based on the physiological studies with animal models, the heterogeneity between small and large cholangioctes was identified: (1) Differential expressed genes between two types were identified by microarray analysis, suggesting the functional difference between small and large bile ducts [64]; (2) Morphological difference was found by histological analysis both from normal condition and CBDL-induced cholestatic condition that large bile ducts looks more columnar compared to small ducts [65]. (3) Large cholangiocytes, rather than small cholangiocyte, reacted to liver injury induced by carbon teterchloride $\left(\mathrm{CCl}_{4}\right)$ or common bile duct ligation (CBDL) [65-66]; (4) Only large cholangiocytes expressed somatostatin receptor type 2 (SSTR2) and responded to secretin-mediated ductal bile secretion $[65,67-68]$.

\subsubsection{Function of biliary system}

The main physiological function of biliary system is modification of bile produced in hepatocytes and transportation of bile through small and large intrahepatic bile ducts to the gallbladder and to the intestine $[60,63]$.

The biliary epithelium takes part in the regulation of bile formation by re-absorption of some biliary constituents, such as glucose [69], amino acids [70] and bile acid [71]. By absorbing glucose and amino acids from bile, it provides an osmotic gradient facilitating the water flow from bile into cholangiocytes [72-73].

The disordered bile formation and/or bile flow has been observed in patients with cholestatic liver diseases (Table 4), leading to development of biliary fibrosis [74-77]. Cholestatic injury can be detected by the increased serum alkaline phosphatase (ALP) and/or $\gamma$-glutamyl transpeptidase ( $\gamma$-GT) levels at early stage, followed by conjugated bilirubin level at later or more severe stages [78]. 
Table 4. Common cholestatic disorders from human patients

\begin{tabular}{|c|c|c|}
\hline$\underline{\text { Name }}$ & Pathology & Demographics \\
\hline $\begin{array}{l}\text { Primary biliary cirrhosis } \\
\text { (PBC) }\end{array}$ & $\begin{array}{l}\text { Small duct cholangitis, } \\
\text { ductopenia, } \\
\text { ductal proliferation, } \\
\text { interface hepatitis }\end{array}$ & $\begin{array}{l}\text { Predominantly found in } \\
\text { middle age females, } \\
\text { co-exist with autoimmunity }\end{array}$ \\
\hline $\begin{array}{l}\text { Primary sclerosing } \\
\text { cholangitis (PSC) }\end{array}$ & $\begin{array}{c}\text { Periductal fibrosis and inflammation, } \\
\text { absence of bile ducts in some portal } \\
\text { tracts and ductal proliferation in other } \\
\text { portal tracts }\end{array}$ & $\begin{array}{l}\text { More elderly men than women; } \\
\text { co-exist with colitis } \\
\text { with high prevalence }\end{array}$ \\
\hline Drug induced cholestasis & Cholestasis or cholestatic hepatitis & $\begin{array}{l}\text { More common in elderly people; } \\
10 \% \text { of drug induced liver injury } \\
\text { is cholestatic }\end{array}$ \\
\hline Biliary atresia & $\begin{array}{l}\text { Obliteration or discontinuity of } \\
\text { extrahepatic biliary system, } \\
\text { jaundice, } \\
\text { even cirrhosis in the long run }\end{array}$ & $\begin{array}{c}\text { Exclusively in neonatal } \\
\text { population }\end{array}$ \\
\hline
\end{tabular}

Table 4 adapted from [77].

\subsubsection{Bile Production}

Bile is an iso-osmotic fluid with dark green to yellowish brown color, primarily produced by hepatocytes and concentrated in gall bladder [79]. Bile consists of: proteins (globulins, albumins, etc), lipids (phospholipids, cholesterol, etc), carbohydrates, vitamins, mineral salts, and trace elements [80-81]. The major bile components are: bile acids (67\%), phospholipids (22\%), proteins (4.5\%), cholesterol (4\%), and bilirubin $(0.3 \%)$ [81].

Bile formation process requires a concerted regulation of membrane transport systems in both hepatocytes and cholangiocytes [63], since primary bile is generated by hepatocytes [82] and afterwards it is modified by cholangiocytes when passing through biliary structures [83]. A large number of transporters located on both the apical and basolateral membranes of hepatocytes (Table 5) and cholangiocytes (Table 6) have been identified, which play an important role in regulating the physiological biliary homeostasis [84-85]. 
Table 5. Major bile-related transporters in hepatocytes

\begin{tabular}{|c|c|c|c|}
\hline \multicolumn{2}{|r|}{ Apical } & \multicolumn{2}{|c|}{ Basolateral } \\
\hline Name & Function & Name & Function \\
\hline BSEP/ABCB 11 & $\begin{array}{l}\text { Transport of bile acids from } \\
\text { hepatocytes into bile }\end{array}$ & NTCP/SLC10A1 & Uptake of bile acids \\
\hline MRP2/ABCC2 & Export of organic anions & OATP/SLC21A & Transport of bile acids \\
\hline MDR1/ABCB1 & Efflux of cationic drugs & OSTa/OSTb & Export of organic anions \\
\hline MDR3/ABCB4 & $\begin{array}{c}\text { Transport of } \\
\text { phosphatidylcholine (PC) }\end{array}$ & $\begin{array}{l}\text { MRP3/ABCC3 } \\
\text { MRP4/ABCC4 }\end{array}$ & Export of organic anions \\
\hline $\begin{array}{l}\text { ABCG5 } \\
\text { ABCG8 }\end{array}$ & $\begin{array}{c}\text { Export of cholesterol and } \\
\text { sterols }\end{array}$ & NBC4c/SLC4A5 & $\mathrm{Na}^{+}-\mathrm{HCO}^{-}$symporter \\
\hline AE2/SLC4A2 & $\mathrm{Cl}^{-} / \mathrm{HCO}^{-}$anion exchanger & NHE1/SLC9A1 & $\mathrm{Na}^{+} / \mathrm{H}^{+}$exchanger \\
\hline AQP8 & Water channel & SK2 & Potassium channel \\
\hline NHE3/SLC9A3 & $\mathrm{Na}^{+} / \mathrm{H}^{+}$exchanger & SLC12A2 & 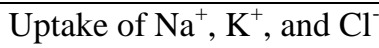 \\
\hline $\mathrm{Cl}^{-}$channel & Exports chloride & & \\
\hline
\end{tabular}

BSEP, bile salt export pump; ABCB, ATP-binding cassette, subfamily B member; MRP, multidrug resistance-associated protein; ABCC, ATP-binding cassette, subfamily $\mathrm{C}$ member; MDR, multidrug resistance protein; ABCG, ATP-binding cassette, subfamily G member; AE, anion exchange protein; SLC, solute carrier family; AQP, aquaporin; NHE, sodium-hydrogen exchanger; NTCP, $\mathrm{Na}^{+}-$ taurocholate cotransporting polypeptide; OATP, organic anion-transporting polypeptide; OST, organic solute transporter; NBC, sodium bicarbonate cotransporter. Table 5 adapted from[80].

Table 6. Major bile-related transporters in cholangiocytes

\begin{tabular}{|c|c|c|c|}
\hline \multicolumn{2}{|r|}{ Apical } & \multicolumn{2}{|c|}{ Basolateral } \\
\hline Name & Function & Name & Function \\
\hline AE2/ SLC4A2 & $\mathrm{Cl}^{-} / \mathrm{HCO}^{-}$anion exchanger & AQP4 & Water channel \\
\hline CFTR & $\mathrm{Cl}^{-}$channel & $\begin{array}{l}\text { MRP3/ABCC3 } \\
\text { MRP4/ABCC4 }\end{array}$ & Export of organic anions \\
\hline NBC4/SLC4A5 & $\mathrm{Na}^{+}-\mathrm{HCO}^{-}$symporter & SK2 & Potassium channel \\
\hline ASBT/SLC10A2 & Uptake of bile acids and $\mathrm{Na}^{+}$ & $\begin{array}{c}\text { Truncated } \\
\text { ASBT/SLC10A2 }\end{array}$ & Export of bile acids and $\mathrm{Na}^{+}$ \\
\hline \multirow[t]{3}{*}{ AQP1 } & Water channel & SLC12A2 & Import of $\mathrm{Na}^{+}, \mathrm{K}^{+}$, and $\mathrm{Cl}^{-}$ \\
\hline & & NHE/SLC9 & $\mathrm{Na}^{+} / \mathrm{H}^{+}$exchanger \\
\hline & & NDCBE/SLC4A8 & $\begin{array}{c}\text { Imports } \mathrm{HCO}^{-} \text {and } \mathrm{Na}^{+} \\
\text {Exports } \mathrm{H}^{+} \text {and } \mathrm{Cl}^{-}\end{array}$ \\
\hline
\end{tabular}


$\mathrm{AE}$, anion exchange protein; CFTR, cystic fibrosis transmembrane conductance regulator; NBC, sodium bicarbonate cotransporter; ASBT, apical sodium dependent bile acid transporter; AQP, aquaporin; NDCBE, $\mathrm{Na}^{+}$-driven $\mathrm{Cl}^{-} / \mathrm{HCO}^{-}$exchanger. Table 6 adapted from [80].

\subsection{Oval cell}

Liver serves as a major detoxifying organ and is capable of self-renewal even in adulthood [86]. Liver regeneration represents a tightly regulated biological process in response to liver injury and involves different cell populations: On one hand, mature hepatocytes possess the ability to proliferate and repopulate the damaged liver; however, when the proliferating ability of mature hepatocytes is suppressed or exhausted, LPC become activated and can differentiate into either hepatocytes or cholangiocytes [87-89].

\subsubsection{Oval cells are K19-positive liver progenitor cells (LPCs)}

In rodents, oval cells (OCs) represent the best studied LPC population. They received this name because of an oval-shaped nucleus with approximately $10 \mathrm{~mm}$ in size and have a high nuclear/cytoplasmic ratio $[88,90]$. OCs are located primarily in the Canals of Hering (Figure 1) [91-92]. The amount of quiescent OCs is very limited under basal conditions, but OCs are activated in a number of stress conditions such as chronic viral hepatitisinduced hepatocellular carcinogenesis, alcoholic liver disease, and nonalcoholic fatty liver disease (NAFLD) [93-96]. OCs are able to differentiate into both hepatocytes and cholangiocytes, and express both biliary marker such as K19 and hepatic markers as alphafetoprotein (AFP) and albumin [97-98].

Recent studies demonstrated that HCC may developed from OCs and hepatocytes [99], which raises the hypothesis that OCs may serve as cancer stem cells contributing to the formation of HCC given that oval cell markers, such as K19 and/or epithelial cell adhesion molecule (EpCAM), were identified in HCC patients and associated with poor prognosis [52, 100-105]. Of note, OCs and liver cancer stem cells share similar markers, such as EpCAM [105], which serves as proliferation promoting regulators in the cancer development [106]. However, both LPCs and liver cancer stem cells represent a 
heterogeneous population with various differentiation features [99, 107], further comprehensive clarification studies still need to be carried out.

\subsubsection{Diverse signaling pathways during oval cell differentiation}

As mentioned above, OCs can be activated during chronic liver injury and capable of differentiating towards both cholangiocytes and hepatocytes depending on the activation of either Wnt or Notch signaling, respectively [108]. Animal studies showed that Wnt signaling was induced in cholestatic livers, coupled with increased OC activation and atypical ductular proliferation (ADP). Isolated LPCs from cholestatic livers showed nuclear localization of $\beta$-catenin in response to Wnt3a stimulation in vitro [109]. Besides, activation of $\mathrm{Wnt} / \beta$-catenin pathway in vitro was sufficient to induce proliferation of LPC [110]. A correlation between LPC activation and upregulated Wnt signalinghas also been demonstrated in patients with chronic liver diseases such as acute hepatitis (AH) [111].

Several investigations based on rodent models demonstrated that Notch2 signaling is involved biliary development, growth, and regeneration [112-115]. As response to cholestatic injury, expression of Notch2 was upregulated in both cholangiocytes and OCs $[108,116]$. Moreover, tubule formation is critical in biliary regeneration to reconstitute the three-dimensional tree-like structure of biliary system and recent study showed that this process is impaired in liver-specific Notch-2 KO mice whereas activation of OC differentiation into cholangiocytes is not significantly affected [116]. In agreement with that, paucity of bile ducts in patients with Alagille syndrome (AGS) is associated with impaired biliary differentiation of OCs [117], consistent with previous finding that mutations of Notch ligand Jagged1 leads to AGS [118-119].

\subsection{Animal models for biliary injury}

A number of murine models have been introduced in order to mimic the humancholestatic disorders [120]. Generally, these animal models can be categorized into three groups: (1) genetically manipulated animals such as multidrug resistance gene 2 (Mdr2) KO mice 
[121-122]; (2) animals treated with xenobiotic drugs such as dihydrocollidine [123-124] or bile acids such as cholic acid (CA) [125-126]; (3) animals subjected to mechanical cholestasis via operation such as CBDL [127].

\subsubsection{Chronic feeding with 3,5-diethoxycarbonyl-1,4-dihydrocollidine (DDC)}

Chronic feeding with a diet containing 0.1\% 3,5-diethoxycarbonyl-1,4-dihydrocollidine (DDC) represents a well-established murine model of xenobiotic-induced cholestatic disease [124, 128-129]. Long-term treatment with this porphyrinogenic drug leads to formation of protoporphyrin plugs that obstruct intrahepatic bile ducts thereby resulting in biliary injury peaking at 4 weeks after beginning of DDC treatment. DDC causes ductular reaction, biliary fibrosis and increased serum bilirubin levels [124]. Notably, DDC-induced ductular proliferation can be clearly distinguished from ductular proliferation caused by mechanical obstruction of common bile duct ligation, in that the formation is characterized by poorly defined lumen (Figure 2a), and is therefore termed as "atypical ductular proliferation" [123].
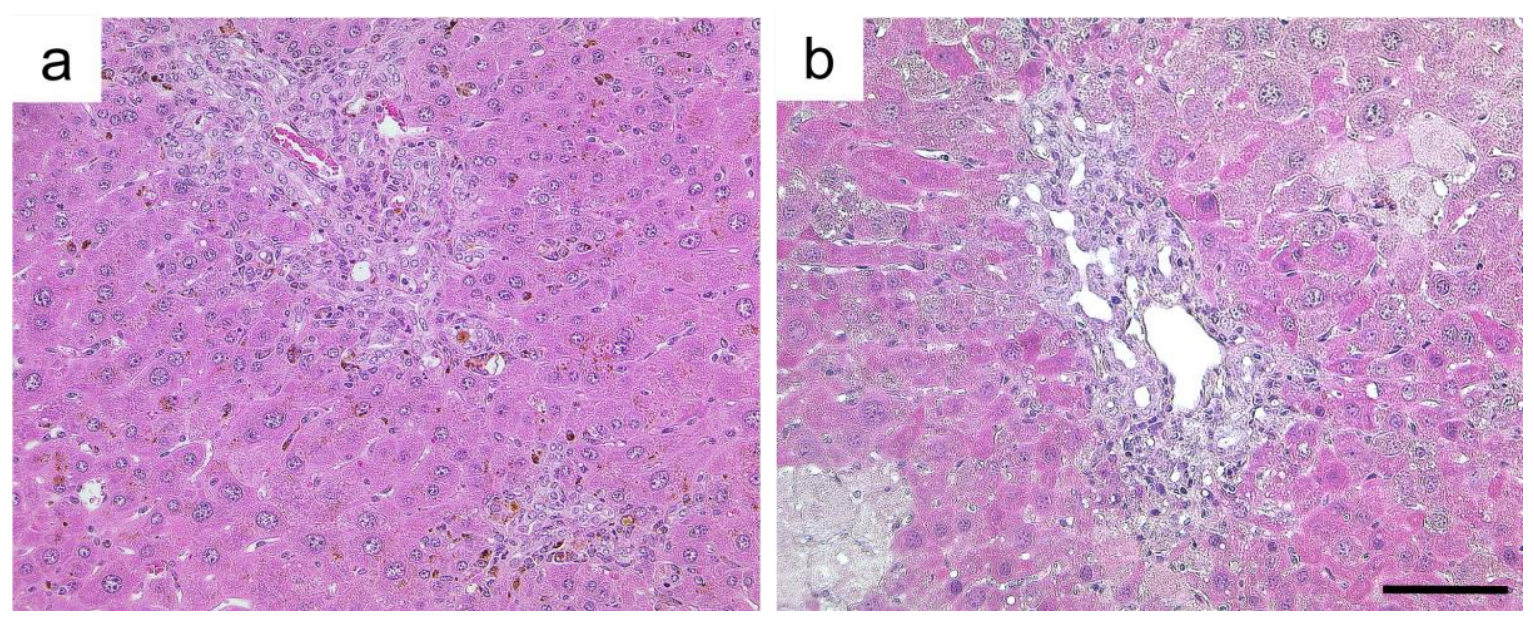

Figure 2. Different types of ductular proliferation in regenerating livers. (a) The atypical ductular proliferation (ADP) in 4-week DDC-fed mouse is characterized by extended and anastomosing structure with poorly defined lumen. (b) 21 days after common bile duct ligation, liver exhibits a large amount of bile ducts with open lumen. Scale bar $=100 \mu \mathrm{m}$. 
Chronic administration of DDC also induces the activation and proliferation of oval cells characterized by strong A6-positive staining [90, 123, 130], and recent study showed that hepatocyte growth factor (HGF)/c-Met signaling regulates the oval cell reaction in response to DDC [131]. Besides, a report described an association between DDC-induced oval cell activation and liver cancer development using transgenic mice expressing hepatitis B virus $\mathrm{X}(\mathrm{HBx})$ protein. In these mice, DDC treatment resulted in increased numbers of OCs and development of HCCs and cholangiocellular carcinomas after 7 months [132].

\subsubsection{Common bile duct ligation (CBDL)}

Cholangiocytes composing large bile ducts (diameter $>15 \mu \mathrm{m}$ in rat) are the major cells affected by the severe obstructive injury caused by CBDL [68]. In the early stage after operation (within 2 days), animals suffer excessive accumulation of hydrophobic bile acids, which activate apoptotic signaling pathways [133]. A key component of initial inflammatory response to cholestasis [134], neutrophil infiltration can also be observed three days after CBDL $[127,135]$. An increased proinflammatory cytokine synthesis and marked proinflammatory response is elicited by altered Kupffer cell function [136], coupled with extensive epithelial apoptosis and progression of necrosis [137].

Although accumulation of hydrophobic bile salts can be partially compensated by cytoprotective mechanisms such as alterations in bile acid synthesis, transport, and detoxification, the cholestatic liver injury cannot be fully rescued [138-139]. As a response to CBDL, an intensive ductular reaction takes place in the elongated and fibrotic portal area. It is characterized by increased numbers of bile ducts with open lumens (Figure 2b), reaches its peak around 5 days after CBDL and is reduced to continuously low levels afterwards (ranging 3-7 days) [127, 140].

In long-term extrahepatic cholestasis, the marked pathogenic feature is the development of liver fibrosis [127, 141]. Hepatic stellate cells (HSC) and myofibroblasts are activated in response to chronic injury and synthesize extracellular matrix (ECM) components that lead 
to progressive liver scarring [127, 142-143]. Chronic injection of $\mathrm{CCl}_{4}$ is another wellestablished method to induce toxin-mediated liver fibrosis, which would result in formation of scarring fibers generally after 4 weeks of treatment [144]. As mentioned above, only large cholangiocytes (not small cholangiocytes) react to CBDL- and $\mathrm{CCl}_{4-}$ induced liver damage, and the proliferating cholangiocytes originated from existing biliary epithelium in CBDL-induced ductal proliferation [145].

\subsection{Aim of this study}

K19 represents the most widely used marker of biliary epithelia and hepatic progenitor cells; however, its functional significance in both cell populations remains unknown. Recently, K19 G17S variant was found in patients with cholestatic liver disease termed as primary biliary cirrhosis [57] whereas K19 expression within hepatocellular carcinoma was described to constitute a "stemness"-related marker that is associated with poor prognosis.

To further elucidate the importance of K19 in biliary/hepatic progenitor cell systems, I analyzed K19 knockout mice both under basal condition and in two well-established murine stress models, i.e. chronic feeding with DDC-containing diet and CBDL.

In my thesis, I focused on following questions:

- What is the importance of K19 in the unstressed biliary epithelia?

- How does the K19 loss affect the morphology of the biliary keratin network?

- Does K19 affect the process of bile production and secretion?

- What is the importance of K19 in selected biliary/progenitor stress models?

- Does K19 affect the development of biliary fibrosis? 


\section{Material and Methods}

\subsection{Materials}

\subsubsection{General equipment and consumables}

\subsubsection{General equipment}

Table 7. List of general experimental equipments

\begin{tabular}{|c|c|}
\hline Name & Company \\
\hline 7500 Fast Real time PCR System & Applied Biosystems \\
\hline ED Precision Balance & Sartorius \\
\hline Horizontal electrophoresis system (Sub-Cell GT Cell) & Bio-Rad \\
\hline Cooling Centrifuge 5417R & Eppendorf \\
\hline Beckman DU640 Spectophotometer & Beckman Coulter \\
\hline Cryostat HM 550 & Microm \\
\hline Axioskop & Carl Zeiss Microscopy \\
\hline QImaging QICam CCD digital camera (QICAM Fast 1394) & Qimaging \\
\hline Hypercassette (18 x $24 \mathrm{~cm})$ & GE Healthcare \\
\hline Leica Application Suite v4.2 software & Leica microsystems \\
\hline Microscope (DM 5500B) & Leica microsystems \\
\hline NanoDrop 2000c & Thermo Scientific \\
\hline pH-Meter (Seven Easy ph S20-K) & Mettler-Toledo \\
\hline Pipettes & Eppendorf \\
\hline PowerPac Basic Power Supply & Bio-Rad \\
\hline Tetra Blotting Module & Bio-Rad \\
\hline Mini-PROTEAN Tetra system & Bio-Rad \\
\hline PCR Thermocycler & Bio-Rad \\
\hline Thermomixer Comfort & Eppendorf \\
\hline UV Illuminator Modell 2011 & LKB \\
\hline Water bath Haake W13 & Fisons \\
\hline Luminescent Image Analyzer LAS 4000 System & Fujifilm \\
\hline
\end{tabular}




\begin{tabular}{|c|c|}
\hline Name & Company \\
\hline Speed vacuum centrifuge & Eppendorf \\
\hline Ice machine AF200 & Scotsman Ice Systems \\
\hline Magnetic stirrer MR 3001 & Heidolph \\
\hline Microwave oven 800 & SEVERIN \\
\hline Pipetus & Heidolph \\
\hline Shaker Polymax 1040 & Cell Path \\
\hline M.I.S.T. 12 Immunostaining tray & BioTek \\
\hline Fluorescence microplate reader & FMI \\
\hline Temperatur-Kontrollmodul TKM-0904 & VWR \\
\hline Potter-Elvehjem Tissue Grinder with Smooth pestle & \\
\hline
\end{tabular}

\subsubsection{Consumables}

Table 8. List of consumables

\begin{tabular}{|c|c|}
\hline$\underline{\text { Name }}$ & Company \\
\hline 96well plates & Nunc \\
\hline Coverslips & Roth \\
\hline Cryotubes & Nunc \\
\hline Disposable Scalpels sterile & B.Braun \\
\hline Falcon 2059 polypropylene tube & $\mathrm{BD}$ \\
\hline Filter papers & Whatman \\
\hline Forceps & $\mathrm{B} 2 \mathrm{~B}$ \\
\hline Injection needles & B.Braun \\
\hline Hyperfilm ECL (18 x 24 cm) & GE healthcare \\
\hline Polystyrene tubes & $\mathrm{BD}$ \\
\hline Polyvinylidene fluoride (PVDF) membrane & Millipore \\
\hline Safe-Lock Eppendorf tubes & Eppendorf \\
\hline Glassware & Schott \\
\hline Slides & Roth \\
\hline
\end{tabular}




\begin{tabular}{|c|c|}
\hline Name & Company \\
\hline Super Frost slides & Roth \\
\hline Tweezers & B2B \\
\hline $\begin{array}{c}\text { Amicon Ultra-0.5 Centrifugal Filter Unit } \\
\text { with Ultracel-10 membrane }\end{array}$ & Millipore \\
\hline Serological pipettes & Corning \\
\hline Sterile filter-tips & Sarstedt \\
\hline Microtubes & Sarstedt \\
\hline UV cuvettes & Brand \\
\hline Tissue processing/embedding cassettes & Simport \\
\hline Dako Pen & Dako \\
\hline PERMA-HAND Suture (1678H), Size: $5-0$ & Ethicon \\
\hline
\end{tabular}

\subsubsection{Kits, enzymes, and commercial solutions}

Table 9. List of commercial kits, enzymes and solutions

\begin{tabular}{|c|c|}
\hline$\underline{\text { Name }}$ & Company \\
\hline DNeasy Blood \& Tissue Kit & Qiagen \\
\hline Rneasy Mini Kit & Qiagen \\
\hline Rneasy Micro Kit & Qiagen \\
\hline DNA Taq Polymerase with 10x reaction buffer & Fermentas \\
\hline Proteinase $\mathrm{K}$ & Qiagen \\
\hline SYBR Green qPCR SuperMix & Applied Biosystems \\
\hline Dnase Set (Rnase-Free) & Qiagen \\
\hline Restore Western Blot Stripping Buffer & Thermo Scientific \\
\hline Oligo $(\mathrm{dT})_{20}$ Primer & Invitrogen \\
\hline Super Script II reverse Transcriptase & Invitrogen \\
\hline Bio-Rad Protein assay & Bio-Rad \\
\hline Serum bile acid assay kit & DiaSys \\
\hline RNAqueous-Micro Kit & Life technologies \\
\hline Prolong Gold Antifade Reagent with DAPI & Invitrogen \\
\hline
\end{tabular}




\begin{tabular}{|c|c|}
\hline Name & Company \\
\hline Antigen Unmasking Solution & Vector labs \\
\hline Vectastain ABC kit & Vector labs \\
\hline Vector VIP substrate kit for peroxidase & Vector labs \\
\hline PageRuler Prestained Protein Ladder & Fermentas \\
\hline GeneRuler 1 kb Plus DNA Ladder & Thermo Scientific \\
\hline ECL Prime Western Blotting Detection Reagents & GE Healthcare \\
\hline ECL Western Blotting Detection Reagents & GE Healthcare \\
\hline
\end{tabular}

\subsubsection{Chemicals, buffers/ solutions}

Table 10. List of chemicals

\begin{tabular}{|c|c|}
\hline$\underline{\text { Name }}$ & Company \\
\hline Acetic Acid (100\%) & Merck \\
\hline Acetone & AppliChem \\
\hline Acrylamide/ Bisacrylamide Solution (30\%) & Sigma \\
\hline Agarose & Biozym \\
\hline Albumin bovine Fraction $\mathrm{V}$ & Serva \\
\hline Ammonium acetate & Sigma \\
\hline Ammonium bicarbonate & Sigma \\
\hline Ammonium chloride & Sigma \\
\hline Ammonium persulfate & Sigma \\
\hline Ammonium sulfate & Sigma \\
\hline Bradford Reagent & Bio-Rad \\
\hline Bromphenol Blue sodium salt & Sigma \\
\hline Calcium Chloride & Sigma \\
\hline Carprofen & Pfizer \\
\hline Citric acid monohydrate & Fluka \\
\hline Chloramines-T & Sigma \\
\hline Coomassie brilliant blue (R250) & Sigma \\
\hline
\end{tabular}




\begin{tabular}{|c|c|}
\hline$\underline{\text { Name }}$ & Company \\
\hline Diethylpyrocarbonate (DEPC) water & Invitrogen \\
\hline Deoxynucleotides Set (dNTP) & Invitrogen \\
\hline DL-Dithiothreitol (DTT) & Sigma \\
\hline Empigen BB Detergent & Sigma \\
\hline Enrofloxacin & Bayer \\
\hline Entellan & Merck \\
\hline Eosin $\mathrm{G}(0.5 \%)$ & Merck \\
\hline Ehrlich's solution & Sigma \\
\hline Ethanol & Sigma \\
\hline Ethidium Bromide & Sigma \\
\hline Ethylenediaminetetraacetic acid (EDTA)- disodium salt & Roth \\
\hline Formaldehyde (37\%) & Roth \\
\hline Glucose & Merck \\
\hline Glycerin & Roth \\
\hline Glycerol & Serva \\
\hline Goat serum & Invitrogen \\
\hline Haematoxylin & Merck \\
\hline Hydrochloric Acid (37\%) & Sigma \\
\hline Hydrogen peroxide $\left(\mathrm{H}_{2} \mathrm{O}_{2}\right)(30 \%)$ & Fischer \\
\hline Isofluran & Abbott \\
\hline Isopropanol & Sigma \\
\hline Magnesium chloride & Sigma \\
\hline Methanol & Sigma \\
\hline Methylbutane & Merck \\
\hline Methyl Green & Sigma \\
\hline Milk powder & Roth \\
\hline Mounting Medium & Immunotech \\
\hline Sodium hydroxide pellet & AppliChem \\
\hline Nonidet P40 (NP 40) & Roche \\
\hline Orange $\mathrm{G}$ & Merck \\
\hline
\end{tabular}




\begin{tabular}{|c|c|}
\hline$\underline{\text { Name }}$ & Company \\
\hline Paraformaldehyde & Merck \\
\hline Perchloric acid & Fluka \\
\hline pH Meter-calibration solutions & Merck \\
\hline Phenylmethanesulfonyl fluoride (PMSF) & Sigma \\
\hline $10 \times$ Phosphate Buffered Saline (PBS) & Gibco \\
\hline Ponceau S & Merck \\
\hline Potassium Chloride & Merck \\
\hline Potassium hexacyanoferrate (2) trihydrate & Sigma \\
\hline Potassium phosphate monobasic & Sigma \\
\hline Protease Inhibitor Cocktail & Sigma \\
\hline Protoporphyrin IX disodium salt & Sigma \\
\hline RNAlater RNA stabilization Buffer & Life technologies \\
\hline RNAlater-ICE RNA stabilization Buffer & Life technologies \\
\hline Sodium dodecylsulfate (SDS) & Roth \\
\hline Sodium dihydrogenphosphate 2-hydrate $\left(\mathrm{NaH}_{2} \mathrm{PO}_{4}\right)$ & Roth \\
\hline Sodium acetate trihydrate & Roth \\
\hline Sodium carbonate $\left(\mathrm{Na}_{2} \mathrm{CO}_{3}\right)$ & Merck \\
\hline Sodium chloride & VWR \\
\hline Sodium dihydrogen phosphate & Sigma \\
\hline Sodium hydrogen carbonate & Merck \\
\hline Sodium hydroxide & Merck \\
\hline Sucrose & Sigma \\
\hline Sulphuric acid $\left(\mathrm{H}_{2} \mathrm{SO}_{4}\right)$ & Merck \\
\hline Tetramethylethylenediamine (TEMED) & Sigma \\
\hline Trans-4-hydrox-L-proline & Sigma \\
\hline Tris (tris-hydroxymethyl-aminomethane) & Sigma \\
\hline Tri-sodium citrate 2 -hydrate & Roth \\
\hline Triton $\mathrm{X}-100$ & Sigma \\
\hline Tween 20 & Roth \\
\hline Xylene & J.T. Baker \\
\hline
\end{tabular}




\begin{tabular}{|c|c|}
\hline Name & Company \\
\hline ß-Mercaptoethanol & AppliChem \\
\hline
\end{tabular}

Unless stated otherwise, all buffers/ solutions in table 2.5 were prepared with either distilled water or Millipore water (Millipore, Billerica, USA).

Table 11. List of experimental buffers/ solutions

\begin{tabular}{|c|c|}
\hline$\underline{\text { Buffer / Solution }}$ & Composition \\
\hline $1 \mathrm{x}$ Phosphate buffered saline (PBS) & $\begin{array}{c}137 \mathrm{mM} \mathrm{NaCl} \\
2,7 \mathrm{mM} \mathrm{KCl} \\
10 \mathrm{mM} \mathrm{Na}_{2} \mathrm{HPO}_{4} \\
1,8 \mathrm{mM} \mathrm{KH}_{2} \mathrm{PO}_{4} \\
\text { Adjust pH to } 7,4 \text { with } \mathrm{HCl} \\
\text { Distilled water to } 1 \mathrm{~L}\end{array}$ \\
\hline TX buffer for High Salt Extraction & $\begin{array}{c}1 \% \text { Triton X-100 } \\
5 \mathrm{mM} \text { EDTA in } 1 \times \text { PBS (pH 7.4) } \\
1 \mathrm{mM} \text { PMSF (add freshly before use) } \\
0.2 \% \text { Protease inhibitor cocktail (add freshly before use) }\end{array}$ \\
\hline PBS-T for washing & $0.1 \%$ Tween-20 in $1 \times$ PBS \\
\hline $\begin{array}{l}\text { Acetate-citrate buffer (pH 6.5) } \\
\text { For hydroxyproline assay: 1L }\end{array}$ & $\begin{array}{c}0.2 \mathrm{M} \text { Citric acid } \\
0.2 \mathrm{M} \text { Acetic acid } \\
0.4 \mathrm{M} \text { Sodium acetate } \\
0.85 \mathrm{M} \mathrm{NaOH} \\
\text { Add water to I L }\end{array}$ \\
\hline $\begin{array}{l}\text { 10x running buffer } \\
\text { for SDS-PAGE (1 L) }\end{array}$ & $\begin{array}{c}\text { 30,2 g Tris }(250 \mathrm{mM}) \\
144 \mathrm{~g} \text { Glycine }(1,92 \mathrm{M}) \\
10 \mathrm{~g} \text { SDS }(1 \%, \mathrm{w} / \mathrm{v})\end{array}$ \\
\hline $\begin{array}{l}\text { Homogenization buffer } \\
\text { for protein isolation }\end{array}$ & $\begin{array}{c}0.187 \mathrm{M} \text { Tris-HCl (pH 6.8) } \\
3 \% \text { SDS } \\
5 \text { mM EDTA }\end{array}$ \\
\hline
\end{tabular}




\begin{tabular}{|c|c|}
\hline$\underline{\text { Buffer / Solution }}$ & Composition \\
\hline Staining solution for SDS-PAGE: 1L & $\begin{array}{l}0.5 \mathrm{~g} \text { Coomassie R250 } \\
250 \mathrm{ml} \text { Isopropanol } \\
100 \mathrm{ml} \text { acetic acid } \\
650 \mathrm{ml} \text { distilled water }\end{array}$ \\
\hline Resolving buffer for WB & $1.5 \mathrm{M}$ Tris- $\mathrm{HCl}$ in distilled water, $\mathrm{pH} 8.8$ \\
\hline Stacking buffer for WB & $0.5 \mathrm{M}$ Tris- $\mathrm{HCl}$ in distilled water, $\mathrm{pH} 6.8$ \\
\hline Blocking buffer for WB & $5 \%(\mathrm{w} / \mathrm{v})$ milk powder in PBS-T \\
\hline 10x Transferring buffer for WB: 1L & $\begin{array}{c}\text { 30,4 g Tris } \\
72,1 \mathrm{~g} \text { Glycin } \\
\text { Distilled water to } 1 \mathrm{~L}\end{array}$ \\
\hline $1 \times$ Transferring buffer for WB: $1 \mathrm{~L}$ & $\begin{array}{l}100 \mathrm{ml} 10 \mathrm{x} \text { transferring buffer } \\
200 \mathrm{ml} \text { Methanol } \\
\text { Distilled water to } 1 \mathrm{~L}\end{array}$ \\
\hline Destaining solution for SDS-PAGE: 1L & $\begin{array}{c}95 \mathrm{ml} \text { Isopropanol } \\
95 \mathrm{ml} \text { acetic acid } \\
810 \mathrm{ml} \text { distilled water }\end{array}$ \\
\hline $\begin{array}{c}\text { 50x TAE (Tris-aetate-EDTA) } \\
\text { buffer stock ( } \mathrm{pH} 8.3) \\
\text { for agarose gel electrophoresis }\end{array}$ & $\begin{array}{c}242 \mathrm{~g} \text { Tris } \\
53,1 \mathrm{ml} \text { acidic acid } \\
100 \mathrm{ml} 0,5 \mathrm{M} \text { EDTA } \\
\text { distilled water to } 1 \mathrm{~L}\end{array}$ \\
\hline $\begin{array}{l}4 \mathrm{x} \text { reducing Laemmli Buffer } \\
\text { for SDS-PAGE }(100 \mathrm{ml})\end{array}$ & $\begin{array}{c}40 \mathrm{ml} \text { Glycerol } \\
8 \mathrm{~g} \mathrm{SDS} \\
8 \mathrm{ml} \text { ß-Mercaptoethanol } \\
0,02 \mathrm{~g} \mathrm{Bromophenol} \mathrm{blue} \\
25 \mathrm{ml} \text { 1M Tris-HCl (pH 6.8) } \\
\text { Add distilled water to } 100 \mathrm{ml}\end{array}$ \\
\hline
\end{tabular}

\subsubsection{Oligonucleotides}


Oligonucleotides used during this thesis are listed below in table 2.6 and table 2.7. If not stated otherwise, all oligonucleotides were designed based on sequences from musculus species.

Table 12. List of oligonucleotides for quantitative RT-PCR

\begin{tabular}{|c|c|c|c|}
\hline Gene Name & Abbreviation & $\begin{array}{c}\text { Forward Primer } \\
\left(5^{\prime}-3^{\prime}\right)\end{array}$ & $\begin{array}{c}\underline{\text { Reverse Primer }} \\
\left(5^{\prime}-3^{\prime}\right)\end{array}$ \\
\hline Keratin 8 & Krt8 & ggacatcgagatcaccacct & tgaagccagggctagtgagt \\
\hline Keratin 18 & Krt18 & caagtctgccgaaatcagggac & tccaagttgatgttctggtttt \\
\hline Keratin 19 & Krt19 & cggtggaagttttagtggga & agtaggaggcgagacgatca \\
\hline Collagen type 1 & Col1a1 & tgaagaactggactgtcccaacc & gggtccetcgactcctacatctt \\
\hline Keratin 7 & Krt7 & acggctgctgagaatgagtt & cgtgaagggtcttgaggaag \\
\hline $\begin{array}{l}\text { Solute carrier organic } \\
\text { anion transporter } \\
\text { family, member } 1 \mathrm{a} 1\end{array}$ & Slcola1 & atccagtgtgtggggacaat & gcagctgcaattttgaaaca \\
\hline $\begin{array}{l}\text { Potassium inwardly- } \\
\text { rectifying channel, } \\
\text { subfamily J, member } 16\end{array}$ & Kcnj16 & gctttgcctcatgtggcgca & ttgggctctcaccgtgccet \\
\hline $\begin{array}{c}\text { Peroxisome proliferator } \\
\text {-activated receptor, } \\
\text { gamma, coactivator } 1 \\
\text { alpha }\end{array}$ & Ppargc1a & caaccgcagtcgcaacatgctc & gggaacccttggggtcatttgg \\
\hline $\begin{array}{c}\text { Phosphoenolpyruvate } \\
\text { carboxykinase } 1, \\
\text { cytosolic }\end{array}$ & Pck1 & tgcactctgtggggtgccet & cagctcagggttgcaggecc \\
\hline Aquaporin 1 & Aqp1 & ttaggtggctcagccccgct & gccaaatgaccgggcagggt \\
\hline $\begin{array}{l}\text { Transforming growth } \\
\text { factor, beta } 1\end{array}$ & Tgfb1 & gcgtgctaatggtggaccgca & gggggttcgggcactgcttc \\
\hline Somatostatin receptor 2 & Sstr2 & tgagtggtacggaggatggggaga & tcctctgggtctccgtggtctcat \\
\hline $\begin{array}{l}\text { Alkaline phosphatase, } \\
\text { liver/ bone/ kidney }\end{array}$ & Alpl & gggcaatgaggtcacatcca & gtggttcacccgagtggtag \\
\hline Polo-like kinase 3 & Plk3 & ctacagcaccgccatatcgt & ctggttccaacagggtgtgt \\
\hline
\end{tabular}

Oligonucleotides used for screening of K19 mice were described previously [55]. 
Table 13. List of oligonucleotides for K19 genotyping

\begin{tabular}{|c|c|}
\hline$\underline{\text { Name }}$ & $\underline{\mathbf{( 5} \text { - sequence- 3') }}$ \\
\hline mK19- PGK $^{\mathrm{r}}$ (Knock-out) & ctaaagcgcatgctccagact \\
\hline mK19-R2G (Common) & cctgactagattcaagttaactg \\
\hline mK19- \#25 (Wild type) & cggtggaagtttagtggga \\
\hline
\end{tabular}

\subsubsection{Antibodies}

\subsubsection{Primary antibodies for experiments}

Table 14. List of primary antibodies for experiments

\begin{tabular}{|c|c|c|c|}
\hline Antibodies & Host & $\underline{\text { Application (dilution) }}$ & Manufacturer \\
\hline anti 3-actin & mouse & WB & Cell signaling \\
\hline $\begin{array}{c}\text { D237 (Keratin18 } \\
\text { Asp237) }\end{array}$ & rabbit & IHC (1:3000) & Pna Spec \\
\hline Ks 8.7 & mouse & IF (1:10) & Progen \\
\hline Ks 18.04 & mouse & IF (1:10) & Dako \\
\hline anti Ki-67 & rat & IHC (1:100) & DSHB \\
\hline anti Keratin 19 & rat & WB (1:100) & Progen \\
\hline A6 & & IF (1:20) & Dako \\
\hline RCK105 (anti Keratin 7) & Mouse & IF (1:50) $(1: 20)$ & from Dr.Valentina M. Factor \\
\hline pankeratin (Z0622) & Rabbit & IF (1:500) & \\
\hline
\end{tabular}

\subsubsection{Secondary antibodies for Immunoblotting}

Table 15. List of secondary antibodies for Western blotting

\begin{tabular}{|c|c|c|}
\hline \multicolumn{1}{|c|}{ Antibodies } & $\underline{\text { Dilution }}$ & Manufacturer \\
\hline Rabbit anti-guinea pig IgG- HRP & $1: 10,000$ & Invitrogen \\
\hline Goat anti-mouse IgG (H+L), Horseradish Peroxidase Conjugate & $1: 10,000$ & Invitrogen \\
\hline Goat anti-rabbit IgG (H+L), Horseradish Peroxidase Conjugate & $1: 10,000$ & Invitrogen \\
\hline Goat anti-rat IgG (H+L), Horseradish Peroxidase Conjugate & $1: 10,000$ & Invitrogen \\
\hline
\end{tabular}




\subsubsection{Secondary antibodies for Immunohistochemistry}

Table 16. List for secondary antibodies for IHC

\begin{tabular}{|c|c|c|}
\hline$\underline{\text { Antibodies }}$ & $\underline{\text { Dilution }}$ & Manufacturer \\
\hline Biotinylated goat anti-mouse IgG Antibody & $1: 200$ & Vector \\
\hline Biotinylated rabbit anti-rat IgG Antibody & $1: 200$ & Vector \\
\hline Biotinylated goat anti-rabbit IgG antibody & $1: 200$ & Vector \\
\hline Biotinylated goat anti-guinea pig IgG antibody & $1: 200$ & Vector \\
\hline
\end{tabular}

\subsubsection{Secondary antibodies for Immunofluorescence}

Table 17. List for secondary antibodies for IF

\begin{tabular}{|c|c|c|}
\hline Antibodies & $\underline{\text { Dilution }}$ & Manufacturer \\
\hline Alexa Fluor 488 Goat Anti-rat IgG $(\mathrm{H}+\mathrm{L})$ & $1: 200$ & Invitrogen \\
\hline Alexa Fluor 568 Goat Anti-rat IgG $(\mathrm{H}+\mathrm{L})$ & $1: 200$ & Invitrogen \\
\hline Alexa Fluor 488 Goat Anti-mouse IgG $(\mathrm{H}+\mathrm{L})$ & $1: 200$ & Invitrogen \\
\hline Alexa Fluor 568 Goat Anti-mouse IgG $(\mathrm{H}+\mathrm{L})$ & $1: 200$ & Invitrogen \\
\hline Alexa Fluor 488 Goat Anti-rabbit IgG $(\mathrm{H}+\mathrm{L})$ & $1: 200$ & Invitrogen \\
\hline Alexa Fluor 568 Goat Anti-rabbit IgG (H+L) & $1: 200$ & Invitrogen \\
\hline Alexa Fluor 488 Goat Anti-guinea pig IgG (H+L) & $1: 200$ & Invitrogen \\
\hline Alexa Fluor 568 Goat Anti-guinea pig IgG (H+L) & $1: 200$ & Invitrogen \\
\hline Alexa Fluor 555 Donkey Anti-goat IgG (H+L) & $1: 200$ & Invitrogen \\
\hline
\end{tabular}

\subsubsection{Mice}

Wild-type and keratin 19 deficient (K19 -/-) mice were obtained by the breeding of keratin 19 heterozygous (K19 +/-) mice as described previously [55]. All animals were bred from the in-house animal facility of Ulm University. All animals used in the present study were cared for in accordance with the criteria outlined in the European Convention for the Protection of Vertebrate Animals. All experiments were approved by the State of BadenWürttemberg in Germany and the University of Ulm Animal Care Committee. 


\subsection{Methods}

\subsubsection{DNA isolation and genotyping}

DNA isolation was performed according to the DNeasy Blood \& Tissue Kit (Qiagen, Hilden, Germany). After tissue lysis with proteinase K, DNA selectively binds to the silica-based DNeasy membrane, while contaminants pass through. Then DNA is purified through several washing steps and then eluted for future analysis.

$0.4-0.6 \mathrm{~cm}$ long mouse tails were cut and the mixture of Buffer ALT and proteinase $\mathrm{K}$ was added for tissue digestion. After vortexing, the suspension was incubated at $56{ }^{\circ} \mathrm{C}$ overnight. Next, Buffer AL and 100\% ethanol was added for precipitation of DNA and the samples were mixed thoroughly by vortexing. The lysate was transferred to DNeasy Mini spin column and spinned down to bind DNA to DNeasy membrane. Flow-through with contaminants was discarded. Buffer AW1 and Buffer AW2 were added sequentially into the spin column and remaining contaminants were washed away by centrifugation. Then, purified DNA was eluted from spin column in two continuous steps with Buffer AE containing 10mM Tris- $\mathrm{HCl}$ and 0,5 mM EDTA (pH 9,0). DNA solution was kept at $4{ }^{\circ} \mathrm{C}$ for long-term storage.

K19 KO mice were genotyped by polymerase chain reaction (PCR) using genomic DNA isolated from tails. Following PCR mixture was used:

Table 18. PCR mix system with $30 \mu$ for each sample

\begin{tabular}{|c|c|}
\hline Components/ Reagents & Amounts \\
\hline 10x PCR buffer & $3 \mu \mathrm{l}$ \\
\hline $\mathrm{dNTP}(10 \mathrm{mM})$ & $0,6 \mu \mathrm{l}$ \\
\hline $\mathrm{MgCl}_{2}(25 \mathrm{mM})$ & $2,4 \mu \mathrm{l}$ \\
\hline Primers $(10 \mathrm{pM} / \mu \mathrm{l}) \mathrm{x} 3$ & $1,4 \mu \mathrm{l}$ for each primer \\
\hline DNA polymerase $(5 \mathrm{U} / \mu \mathrm{l})$ & $0,18 \mu \mathrm{l}$ \\
\hline Sample DNA & around $100 \mathrm{ng}$ \\
\hline DEPC water & to $30 \mu \mathrm{l}$ \\
\hline
\end{tabular}

The PCR reaction was performed using the following program: 
Table 19. Program for K19 genotyping PCR

\begin{tabular}{|c|c|c|c|}
\hline No. of cycle & Time & Temperature & Note \\
\hline 1 & $5 \mathrm{~min}$ & $94^{\circ} \mathrm{C}$ & Initialization \\
\hline \multirow{3}{*}{35} & $1 \mathrm{~min}$ & $94^{\circ} \mathrm{C}$ & Denaturation \\
\cline { 2 - 4 } & $1 \mathrm{~min}$ & $60^{\circ} \mathrm{C}$ & Annealing \\
\cline { 2 - 4 } & $2 \mathrm{~min}$ & $72^{\circ} \mathrm{C}$ & Elongation \\
\hline 1 & $8 \mathrm{~min}$ & $72^{\circ} \mathrm{C}$ & Final elongation \\
\hline 1 & forever & $4^{\circ} \mathrm{C}$ & Cooling \\
\hline
\end{tabular}

To check whether the K19-genotyping PCR give rise to the anticipated DNA fragments, $1 \%(\mathrm{w} / \mathrm{v})$ agarose gel electrophoresis was performed. The gels were supplemented with 0.5 $\mu \mathrm{g} / \mathrm{ml}$ ethidium bromide to visualize the DNA bands. $1 \times$ TAE (Tris- acetate- EDTA) buffer was used as a running buffer. When placing the gel under ultraviolet (UV) light, ethidium bromide which intercalates between DNA strands generated intense orange fluorescence. A 739 bp fragment represented the K19 null allele, while a 932 bp fragment indicated the K19 WT allele, and both fragments were present in the heterozygous mice. The size of PCR products was determined by comparing them with GeneRuler 1kb Plus DNA Ladder (Thermo Scientific, Schwerte, Germany).

\subsubsection{Mouse experiments}

\subsubsection{Induction of chronic liver injury}

Chronic liver injury was induced in male three-month old wild type (WT) and K19- KO mice (both on FVB/N background) by feeding with 0,1\% 3,5-diethoxycarbonyl-1,4dihydrocollidine supplemented diet (Ssniff, Soest, Germany) [124]. DDC was administrated for 4 weeks. Untreated four-month old male WT and K19-KO mice were used as controls. Littermates obtained by breeding of heterozygous animals were used in all experiments.

After measuring body weight, all mice were sacrificed by $\mathrm{CO}_{2}$ inhalation. Blood was collected by intracardiac puncture for serum extraction. Alanine/ aspartate aminotransferase (ALT/AST), alkaline phosphatase (ALP) and total bilirubin (Bili tot) levels were measured in clinical chemistry department of University Medical Center Ulm. 
Common bile ducts (CBDs), gallbladders (GBs) and colons were taken for histological assessment. CBDs, GBs and colons from untreated animals were also collected for immunofluorescence (IF) and RNA analysis.

Livers were removed, weighed, cut into different pieces and put:

- in formaldehyde for histological analysis

- in liquid nitrogen pre-cooled 2-methylbutane for IF

- in liquid nitrogen for biochemical analyses

- in RNAlater Stabilization Reagent (Life technologies, Darmstadt, Germany) for RNA analysis

\subsubsection{Induction of biliary obstruction}

To induce biliary obstruction, CBDL model was used [127]. Male three-month old WT and K19- KO mice (both on FVB/N background) were anesthetized with isoflurane. Midline laparotomy $(\sim 1 \mathrm{~cm})$ was performed and the bile duct was ligated with PERMA-HAND Suture (Ethicon, Norderstedt, Germany): two ligatures were placed at the proximal portion and distal portion of the bile duct, respectively. The bile duct was then cut between the ligatures. After operation mice were placed on a heat pad (FMI, Seeheim, Germany) to recover. All the operated mice received $5 \mathrm{mg} / \mathrm{kg}$ Enrofloxacin (Bayer, Leverkusen, Germany) as an antibiotic prophylaxis and Carprofen (Pfizer, New York, USA) as an analgesic once per day by subcutaneous injection until sacrifice. Untreated four-month old male WT and K19-KO mice were used as controls.

After measuring body weight, all mice were sacrificed either 5 days or 21 days after CBDL by $\mathrm{CO}_{2}$ inhalation. Blood was collected by intracardiac puncture for serum extraction.

ALT/AST, ALP, Bili tot level were measured in clinical chemistry department of University Medical Center Ulm. 
GBs and livers were processed as described above.

\subsubsection{RNA Isolation}

\subsubsection{Total liver RNA isolation}

Liver RNA was isolated using RNeasy Mini Kit (Qiagen) according to manufacturer's protocol with minor modification.

Briefly, a piece of liver stored in RNAlater stabilization solution (Life technologies) was cut (less than $30 \mathrm{mg}$ ) and homogenized in Buffer RLT containing 1\% (v/v) Bmercaptoethanol. 70\% ethanol was added to the lysate to enable binding of RNA to the RNeasy membrane. Lysate was transferred into RNeasy Mini spin column. RNA selectively bound to RNeasy membrane and the remaining solution passed through during centrifugation. Since even very small amounts of remaining DNA may affect the subsequent RT-PCR analysis, remaining DNA was removed by on-column DNase digestion step using RNase-Free DNase set. First, buffer RW1 was added to RNeasy spin column in order to wash it via centrifugation; then $80 \mu \mathrm{l}$ of DNase-Mix solution (70 $\mu 1$ Buffer RDD + $10 \mu$ l DNase I) was added directly onto the membrane and incubated for 15 min at room temperature for DNase digestion. Afterwards, DNase I was removed by another washing step with Buffer RW1. Subsequently, RNA was purified via two washing steps with Buffer RPE. Finally, RNeasy spin column was placed in a new 1,5 ml microtube and RNA was eluted with RNase-free water through centrifugation. To maximize the RNA yield, the RNA elution step was repeated. RNA was kept at $-80{ }^{\circ} \mathrm{C}$ until further analysis.

\subsubsection{RNA isolation from common bile ducts, gallbladders and colons}

Since RNA amount from tiny piece of tissue like common bile ducts, gallbladders or colons was very limited, RNAqueous-Micro kit (Life technologies) was utilized to enrich maximal concentrated RNA for following real time RT-PCR analysis.

Tissue was homogenized with lysis buffer on ice, then $100 \%$ ethanol was added to the lysate for optimal binding of RNA to the membrane. Lysate solution was loaded onto a Micro filter. During centrifugation with maximum speed, RNA was bound to filter. RNA 
was purified by one washing step with Wash solution 1 and two washing steps with Wash solution 2/3 via centrifugation at maximum speed. By doing so, contaminants were eluted from the filter as flow-through. After discarding the flow-through, empty filter was centrifuged at maximum speed to remove residual fluid and to dry filter. Next, RNA was eluted with pre-heated $\left(75^{\circ} \mathrm{C}\right)$ Elution solution by centrifugation at maximum speed. To maximize the RNA yield, the elution step was repeated with the same volume of Elution solution. DNase I treatment and subsequent DNase inactivation was performed since trace amount of contaminating genomic DNA need to be removed prior to the RT-PCR analysis: DNase I buffer and DNase I were added into eluted RNA solution, the solution was mixed thoroughly by pipetting and incubated at $37{ }^{\circ} \mathrm{C}$ for $20 \mathrm{~min}$. Afterwards, DNase Inactivation Reagent was added into the mixture and the solution was incubated at room temperature for 2 min. DNase Inactivation Reagent was then precipitated by centrifugation at maximum speed. Purified RNA was transferred to a new RNase-free tube and stored at $80{ }^{\circ} \mathrm{C}$ until further analysis.

\subsubsection{RNA Quantification}

RNA concentration was determined by measuring the absorbance with NanoDrop 2000c UV-Vis Spectrophotometer (Thermo Scientific). $1 \mu 1$ of RNA sample was used for measurement and RNase-free water or Elution solution was used as blank. Results were displayed as $\mu \mathrm{g} / \mu \mathrm{l}$.

The ratio of absorbance at 260 and $280 \mathrm{~nm}$ was used to evaluate the purity of RNA. To that end, a ratio of $\sim 2.0$ is generally accepted as pure RNA, while a lower ratio indicates the presence of protein, phenol or other contaminants.

\subsubsection{Reverse Transcription and cDNA translation}

After measuring RNA concentration, $2 \mu \mathrm{g}$ of total liver RNA were reverse-transcribed into cDNA. For RNA from bile duct, gallbladder and colon samples, up to $1 \mu \mathrm{g}$ of total RNA were reverse-transcribed by the same method.

Sample RNA was mixed with Oligo (dT) ${ }_{20}$ Primer (Life technologies) and incubated for 5 $\min$ at $65^{\circ} \mathrm{C}$ to reduce RNA secondary structure. Afterwards, the solution was cooled down 
to $4^{\circ} \mathrm{C}$ to preserve the natural state. After adding 0,1M DTT (Life technologies), Super Script II reverse Transcriptase (Life technologies), and 5 x First strand buffer (Life technologies), the transcription was performed for $50 \mathrm{~min}$ at $42^{\circ} \mathrm{C}$. Then the mixture was incubated for $15 \mathrm{~min}$ at $70^{\circ} \mathrm{C}$ to inactivate the reaction. The obtained cDNA was either used for real-time RT-PCR directly, or stored at $-20^{\circ} \mathrm{C}$.

\subsubsection{Quantitative Real-time RT-PCR}

To detect relative expression of mRNA within different samples, real time RT-PCR was performed with 7500 Fast Real-Time PCR System (Applied Biosystems, Foster City, USA). L7 ribosomal protein transcript was used as internal control and detailed list of specific oligonucleotides can be found in Table 2.6. Every sample was detected in duplicates for each target gene.

Mixture of sample solutions was pipette into MicroAmp Fast Optical 96-well Reaction Plate (Applied Biosystems) using $10 \mu \mathrm{l}$ for each well. The mixture contained

- $1 \mu 1$ of cDNA (for liver, 1:10 diluted cDNA solution was utilized)

- $5 \mu 1$ SYBR Green Master Mix

$-3 \mu 1$ DEPC water

- $1 \mu \mathrm{l}$ of primer mix $(0,3 \mu \mathrm{M}$ forward and reverse primers $)$

The plate was sealed by MicroAmp Optical Adhesive Film (Applied Biosystems) to prevent evaporation of solutions during the reaction. The reaction was carried out with the following program:

Table 20. Program for quantitative real-time PCR

\begin{tabular}{|c|c|c|c|}
\hline No. of cycle & Time & $\underline{\text { Temperature }}$ & Note \\
\hline 1 & $10 \mathrm{~min}$ & $95^{\circ} \mathrm{C}$ & Denaturation and enzyme activation \\
\hline \multirow{3}{*}{45} & 15 second & $95^{\circ} \mathrm{C}$ & Denaturation \\
\cline { 2 - 4 } & $1 \mathrm{~min}$ & $60^{\circ} \mathrm{C}$ & Annealing and Elongation \\
\hline
\end{tabular}


The amount of double stranded DNA generated during the amplification reaction was measured by fluorescent signals generated from the intercalating SYBR Green. $\Delta \Delta \mathrm{C}_{\mathrm{t}}$ method [146] was utilized for quantification of gene expression: the quantification cycle $\left(\mathrm{C}_{\mathrm{q}}\right)$ of target gene is divided by $\mathrm{C}_{\mathrm{q}}$ of $\mathrm{L} 7$ in the same sample for normalization.

\subsubsection{Serum bile acid (SBA) assay}

Bile acids are produced in the liver as metabolic product of cholesterol, which can be secreted into gallbladder or released into the small intestine; Bile acids also can be reabsorbed via hepatic portal blood circulation passing back to liver through enterohepatic circulation. Hence, the elevated serum bile acids level is clinically considered as an indicator specific for biliary injury due to the dysfunction or obstruction of biliary system. To detect bile acid level in the mouse serum, $80 \mu$ l of serum from control animals (1:8 diluted) and 4w-DDC-feeding samples (1:2 diluted) were utilized for SBA assay with serum bile acid assay kit (DiaSys, Holzheim, Germany).

The principle of this assay is the generation of NADH from nicotinamide adenine dinucleotide $\left(\mathrm{NAD}^{+}\right)$via the enzyme 3- $\alpha$ hydroxysteroid dehydrogenase (3- $\alpha \mathrm{HSD}$ ), which converts 3- $\alpha$ hydroxy bile acids to 3- keto steroids. Subsequently, NADH reacts with nitrotetrazolium blue (NBT) in the presence of diaphorase enzyme to form a formazan dye. The dye formation is proportional to bile acids amounts in the serum and can be detected photometrically by measuring absorbance at $540 \mathrm{~nm}$.

$80 \mu \mathrm{l}$ of distilled water (as blank)/ Bile acids Standard (35 $\mu \mathrm{M} / \mathrm{l}) /$ serum samples were mixed with $600 \mu \mathrm{l}$ reconstituted Reagent $\mathrm{R} 1$ containing diaphorase, $\mathrm{NAD}^{+}$, and NBT. After incubation in dark for 4 min at $37^{\circ} \mathrm{C}$, absorbance 1 (A1) was read with Beckman DU640 Spectophotometer (Beckman Coulter, Krefeld, Germany). Then $120 \mu 1$ Reagent 2 containing 3- $\alpha$ HSD was added to the solution in order to start the reaction. After incubation in dark for another $5 \mathrm{~min}$ at room temperature, absorbance 2 (A2) was read with Beckman DU640 Spectophotometer. Finally, by calculating $\Delta \mathrm{A}=[(\mathrm{A} 2-0,85$ A1) Sample/ Standard]- [(A2- 0,85 A1) Blank], in which the factor 0,85 compensates the decrease of absorbance by addition of Reagent 2 , the concentration of bile acids in each sample was 
calculated by the formula: Bile acids $[\mu \mathrm{M} / \mathrm{L}]=(\Delta \mathrm{A}$ Sample $/ \Delta \mathrm{A}$ Standard $) \times 35[\mu \mathrm{M} / \mathrm{L}]$. Of note, $35 \mu \mathrm{M} / \mathrm{L}$ mentioned in the above formula is the concentration of Bile acids Standard. Serum bile acid concentration was displayed at $\mu \mathrm{M} / \mathrm{L}$.

\subsubsection{Hepatic porphyrin assay}

Since DDC blocks the conversion of protoporphyrin IX (PPIX) to heme and thereby results in the formation of porphyrin stones in the liver, hepatic porphyrin assay was conducted to assess the extent of DDC-induced PPIX accumulation [147]. This assay takes advantages of PPIX autofluorescence after appropriate excitation.

Approximately $50 \mathrm{mg}$ of frozen tissue kept in liquid nitrogen was homogenized in $1 \mathrm{ml}$ 0,9 $\mathrm{M}$ perchloric acid in ethanol. After centrifugation at $14,000 \mathrm{rpm}$ for $30 \mathrm{~min}$ at $4{ }^{\circ} \mathrm{C}$, supernatants were collected. Next, PPIX standard serial dilutions in 0,9 M perchloric acid in ethanol were prepared: $500 \mathrm{nM}, 1,000 \mathrm{nM}, 2,000 \mathrm{nM}, 4,000 \mathrm{nM}, 6,000 \mathrm{nM}$ and 10,000 nM. After adding $200 \mu$ l PPIX standard solutions or samples per well, the absorbance values were measured for standard curve by Fluorescence microplate reader (BioTek, Bad Friedrichshall, Germany) with $400 \mathrm{~nm}$ excitation and $605 \mathrm{~nm}$ emission. Finally, PPIX concentration was calculated based on standard curve, and normalized to liver tissue weight as $\mathrm{pM} / \mathrm{mg}$ tissue.

\subsubsection{Protein isolation and Western blot}

\subsubsection{Total liver protein extraction}

Approximately $50 \mathrm{mg}$ of frozen tissue kept in liquid nitrogen was minced in $1 \mathrm{ml}$ homogenization buffer (see chapter 2.1.2) using Potter-Elvehjem Tissue Grinder with Smooth pestle (VWR, Bruchsal, Germany). After incubate at $98{ }^{\circ} \mathrm{C}$ for 5 min to enable protein denaturation, liver lysates were sheared through $1 \mathrm{ml}$ syringe equipped with $22 \mathrm{G}$ needle to fragment the genomic DNA. Finally, lysates were centrifuged at maximum speed at $4^{\circ} \mathrm{C}$ for 2 min to remove non-solubilized cellular debris.

\subsubsection{Protein quantification}


Protein content of each sample was dtermined by protein quantification kit (Bio-Rad, Munich, Germany) based on Bradford method according to the instruction manual:

Serum albumin (BSA) standard serial solutions were prepared as $0 \mathrm{mg} / \mathrm{ml}, 0,2 \mathrm{mg} / \mathrm{ml}, 0,4$ $\mathrm{mg} / \mathrm{ml}, 0,6 \mathrm{mg} / \mathrm{ml}$ and $0,8 \mathrm{mg} / \mathrm{ml}$ in deionized water. $16 \mu \mathrm{l}$ of each standard and sample solutions were added in the UV cuvettes (Brand, Wertheim, Germany). Next, $800 \mu 1$ of diluted dye reagent (1:4 dilution with distilled deionized water) were added to each cuvette. After gentle mixing, the cuvettes were incubated at room temperature for $5 \mathrm{~min}$. During that time, Coomassie blue dye interacted with the basic and aromatic amino acids residues in sample lysates. The absorbance was measured with Beckman DU640 Spectophotometer (Beckman Coulter) at $595 \mathrm{~nm}$. Because absorbance increases over time, samples should be incubated at room temperature for no more than 1 hour. At last, protein concentration was calculated based on the standard curve for BSA.

\subsubsection{Sodium dodecyl sulphate polyacrylamide gel electrophoresis (SDS-PAGE)}

Sodium dodecyl sulphate polyacrylamide gel electrophoresis (SDS-PAGE) was performed to separate proteins based on their molecular weight. In this study, $10 \%$ acrylamide gels were utilized since they allow a convenient separation of most cellular proteins.

Table 21. Composition of $10 \%$ acrylamide gels.

\begin{tabular}{|c|c|c|}
\hline & $\frac{\text { Resolving gel }}{\text { Stacking gel }}$ \\
\hline $\mathbf{H}_{\mathbf{2}} \mathbf{O}$ & $2,05 \mathrm{ml}$ & $1,5 \mathrm{ml}$ \\
\hline Resolving/ stacking buffer & $1,3 \mathrm{ml}$ & $0,65 \mathrm{ml}$ \\
\hline $\mathbf{3 0} \%$ acrylamide & $1,65 \mathrm{ml}$ & $375 \mu \mathrm{l}$ \\
\hline $\mathbf{1 0} \%$ SDS & $50 \mu \mathrm{l}$ & $25 \mu \mathrm{l}$ \\
\hline $\mathbf{1 0} \%$ APS & $25 \mu \mathrm{l}$ & $12,5 \mu \mathrm{l}$ \\
\hline TEMED & $7,5 \mu \mathrm{l}$ & $2,5 \mu \mathrm{l}$ \\
\hline
\end{tabular}

Sample lysates were normalized based on their protein concentration, 1:4 diluted with $4 \mathrm{x}$ reducing Laemmli buffer, incubated at $95{ }^{\circ} \mathrm{C}$ for $1 \mathrm{~min}$ to solubilize SDS and loaded into the wells of gel. To that end, 2-mercaptoethanol in the $4 \mathrm{x}$ reducing Laemmli buffer disrupts the disulfide bonds and proteins are denatured and obtain negative charge due to 
SDS. This enables their separation according to the size of polypeptide chain. PageRuler prestained protein ladder (Bio-Rad) was used as a size standards for both the SDS-PAGE and the subsequent Western blotting. Electrophoresis was performed in $1 \mathrm{x}$ SDS running buffer at $80 \mathrm{~V}$ until the bands run out of the stacking gel. Stacking gel is used to concentrate proteins into thin bands and to allow them to enter the resolving gel at the same time. To separate the proteins, the voltage was increased to $120 \mathrm{~V}$. Afterwards, the gel was either stained with Coomassie R250 staining solution for 30 min then destained with destaining solution overnight to visualize the protein bands on the gel; or a detection of specific protein was carried out via Western blotting.

\subsubsection{Western blot (Immunoblotting)}

In the process of "Western blotting" (or immunoblotting), proteins are transferred to a PVDF membrane. Then the attached proteins on the membrane can be detected by specific antibody-antigen reactions and the signal will be visualized by an enzymatic reaction carried out through horseradish peroxidase (HRP) which is attached to the secondary antibody.

After separation by SDS-PAGE, the protein bands were transferred from gel to a polyvinylidene difluoride (PVDF) membrane pre-activated by methanol and equilibrated in $1 \mathrm{x}$ transfer buffer. The transfer was performed in ice-bath using constant voltage at $110 \mathrm{~V}$ for 1 hour. For an optimal transfer, we used the wet transfer method, and prepared the gel and membrane sandwich in the following sequence: Cathode- filter paper- gel- membranefilter paper- Anode. Then the gel and membrane sandwich was entirely submerged into ice-cold $1 \times$ transfer buffer.

After the transfer, membrane was washed with PBS-T buffer (Phosphate Buffered Saline with $0.1 \%$ Tween-20) for three times 10 min each and then incubated with blocking buffer (5\% milk in PBS-T) for $1 \mathrm{~h}$. Then membrane was exposed to specific primary antibody against the protein of interest at $4^{\circ} \mathrm{C}$ overnight. The membrane was washed directed again with PBS-T three times for $10 \mathrm{~min}$. Subsequently, membrane was incubated for $1 \mathrm{~h}$ at 
room temperature with secondary antibody conjugated with HRP. Of note, secondary antibody against the host is directed in whom the corresponding primary antibody was generated.

After washing with PBS-T three times for 10 min each, either ECL (Enhanced Chemiluminescence) or ECL prime western blotting detection reagent (GE Healthcare, Freiburg, Germany) was added directly onto the membrane according to manufacturer's recommendation. These reagents enable the detection of the target proteins, because chemiluminescence-based signals are proportional to the amount of bound secondary antibody and thereby to the amount of the recognized protein. In principle, after HRP catalyzing oxidation of luminal (i.e. the ECL reagent) in alkaline conditions, luminol become excited and subsequently absorbed to basal state via an emission of light. The light produced by this enhanced chemiluminescence reaction reach peaks after 5-20 minutes and decays slowly thereafter with a half life of approximately 60 minutes. The maximum light emission can be detected at wavelength of $428 \mathrm{~nm}$. After exposing to ECL solution for $5 \mathrm{~min}$ at room temperature, the chemiluminescence generated from target proteins were captured by Luminescent Image Analyzer LAS4000 System (Fujifilm, Düsseldorf, Germany), then the projected digital images of target bands were visualized by ImageQuant LAS 4000 Control Software (Fujifilm).

All detailed information of antibodies and buffers/solutions used for western blotting can be found in chapter 2.1.4.

\subsubsection{Histology}

Paraformaldehyde-fixed samples were dehydrated in a graded ethanol series, embedded in paraffin, and cut into $5 \mu \mathrm{m}$ thin sections for analysis. Sections were either stained with haematoxylin and eosin (H\&E), picro-sirius red (PSR), or used for Immunohistochemistry (IHC) analysis. Images were captured by Leica Microscope (DM 5500B) equipped with Leica Application Suite software V4.1 (Leica Microsystems, Wetzlar, Germany). 


\subsubsection{Hematoxylin \& Eosin (H\&E) staining}

H\&E staining was used to assess the general morphologic changes, the extent of ductular reaction and biliary obstruction:

After deparaffinizing the slides in xylene for 2 min twice, sections were incubated with descending serial ethanol dilutions $(100 \%$ x 2, 96\%, 90\%, 80\%, 70\%) for 2 min per each step, then sections were washed with running distilled water for $5 \mathrm{~min}$. Next, slides were incubated in filtered Mayer's hemalum solution (Merck, Darmstadt, Germany) for 5 min, and washed in warm running tap water for another $10 \mathrm{~min}$. Then, slides were stained in Eosin G solution (Merck) for 2 min and washed in cool running tap water until water became clean. Finally, after dehydrating with ascending serial ethanol solutions (70\%, $80 \%, 90 \%, 96 \%, 100 \% \times 2$ ), sections were incubated in Xylene for 5 min twice and mounted with cover slip containing Entellan (Merck). The slides were dried overnight before checking under light microscope.

During H\&E staining, cell nuclei and other basophilic structures are stained with blue color by Hematoxylin, while cytoplasm was colored with red or pink-orange by eosin.

The assessment of ductular reaction was performed independently by two experienced researchers based on the following criteria:

- score 0 , no reaction;

- score 1, weak;

- score 2, mild;

- score 3, abundant.

\subsubsection{Picro-sirius-red staining}

Picro-sirius-red staining was carried out to visualize collagen fibers in order to evaluate the extent of biliary fibrosis: 
After deparaffinizing in Xylene for 10 min twice, sections were incubated with descending serial ethanol solutions $(100 \%$ x 2, 90\%, $70 \%)$ for 5 min each step, then washed with running distilled water for $5 \mathrm{~min}$. Next, slides were incubated in picro-sirius-red solution [0.1\% (w/v) of Direct Red 80 (Sigma, Munich, Germany) in saturated aqueous solution of picric acid (Sigma)] for $1 \mathrm{~h}$, and washed in acidified water $[0.5 \%(\mathrm{v} / \mathrm{v})$ acetic acid in distilled water] for 5 min twice. Then, slides were dehydrated with ascending serial ethanol solutions $(70 \%, 100 \% \times 2)$ for 3 min each step and incubated in Xylene for 5 min twice. At last, slides were mounted with cover slip containing Entellan (Merck). Slides were dried overnight before analysing them under light microscope.

Fibrous areas in the liver were stained with the red color of brilliant red. Fibrosis scoring was performed in a blinded way by an experienced pathologist using following scoring system:

- score 0 , indicating no fibrosis;

- score 1, portal fibrosis;

- score 2, incomplete portoportal fibrosis;

- score 3, complete portoportal fibrosis;

- score 4, cirrhosis.

\subsubsection{Immunohistochemistry}

To investigate the percentage of proliferating/ apoptotic cholangiocytes in each bile duct, IHC staining was performed using ABC Staining System (Vector labs, Eching, Germany). Given avidin have high affinity for biotin and possess four biotin binding site, Avidin DH (Reagent A) and biotinylated enzyme (Reagent B) in ABC kit can be mixed to form Avidin/Biotinylated enzyme Complex (ABCs) and specifically binding to the biotinylated secondary antibody. After adding the substrate solution containing HRP, substrates (typically containing streptavidin) bind to biotins and $\mathrm{HRP}\left(\mathrm{H}_{2} \mathrm{O}_{2}\right.$ as oxidizing agent) 
catalyzes the conversion of chromogenic substrates to colored products, which can be detected at the antigenic site under microscope.

After deparaffinizing in Xylene for 10 min twice, sections were hydrated with descending serial ethanol solutions $(100 \%$ x 2, 96\%, 90\%, 80\%, 70\%) for 2 min each step and washed with running distilled water for 5 min. Next, slides were incubated in 1\% Antigen Unmasking Solution (Vector labs) at $900 \mathrm{~V}$ in the microwave oven until the solution started boiling. Afterwards, the microwave was switched to $600 \mathrm{~V}$ and the incubation was performed for $20 \mathrm{~min}$. After cooling down for around $20 \mathrm{~min}$, slides were washed in distilled water for $5 \mathrm{~min}$. Slides were then incubated in $3 \% \mathrm{H}_{2} \mathrm{O}_{2}$ for $10 \mathrm{~min}$ to eliminate endogenous peroxidase activity and washed in distilled water for another $5 \mathrm{~min}$.

Tissue area was marked with Dako Pen (Dako, Hamburg, Germany) and incubated with blocking buffer containing 2\% BSA in Tris Base Saline buffer with 0.1\% Tween-20 (TBST) for $30 \mathrm{~min}$. Primary antibody was added onto the tissue area and sections were incubated in humid Immunostaining tray (Cell Path, Newton, UK) for $1 \mathrm{~h}$ at room temperature (or $4{ }^{\circ} \mathrm{C}$ overnight). After washing with TBS-T buffer briefly 3 times, biotinylated secondary Antibodies (Vector labs) were added onto tissue areas and slides were incubated in humid Immunostaining tray for $30 \mathrm{~min}$ at room temperature, then washed with TBS-T buffer briefly 3 times. Afterwards, sections were incubated with prepared Vectastain working solutions (Vector labs) in humid Immunostaining tray at room temperature for $30 \mathrm{~min}$ and washed with TBS-T buffer briefly 3 times. Finally, prepared Vector VIP substrate solution (Vector labs) was added onto the tissue area and slides were incubated in humid Immunostaining tray at room temperature. The formation of the signal was monitored under light microscope and the reaction was discontinued until staining of desired intensity developed.

After washing with distilled water briefly 3 times, slides were counterstained with $56^{\circ} \mathrm{C}$ warm methyl green (Sigma) for $10 \mathrm{~min}$ to visualize the nuclei. After washing with distilled water 3 times, slides were dehydrated with ascending serial ethanol solutions $(70 \%, 80 \%$, 
$90 \%, 96 \%, 100 \%$ x 2) 1 min each step. Sections were then incubated in Xylene for 5 min twice and mounted with cover slip containing Entellan (Merck). The slides were dried overnight before analyzing them under light microscope.

Using this method, antigens were stained with intense violet color by VIP (Vector labs), while background appeared light green due to methyl green. The percentage of stained biliary epithelial cells within bile ducts was calculated. To that end, cholangiocytes were categorized into positive (purple) and negative (green). The percentage of positive cells was calculated as purple divided by the sum of purple and green cells and at least 20 bile ducts were evaluated per slide.

\subsubsection{Immunofluorescence}

Liver tissues were frozen in methylbutane pre-cooled in liquid nitrogen, embedded in Tissue-Tek O.C.T Compound (Sakura, Staufen, Germany) and cut into $2 \mu \mathrm{m}$ thin sections:

Sections were fixed in pre-cooled acetone for $10 \mathrm{~min}$, dried, and stored at $-80{ }^{\circ} \mathrm{C}$. Before use, sections were washed 3 times in TBS-T buffer. After marking the tissue with Dako Pen (Dako), sections were incubated with blocking buffer in humid Immunostaining tray (Cell Path) for $30 \mathrm{~min}$ at room temperature. Next, primary antibodies were diluted with blocking buffer and added onto the sections. Slides were incubated in humid Immunostaining tray for $1 \mathrm{~h}$ at room temperature (or $4{ }^{\circ} \mathrm{C}$ overnight) and then washed 3 times in TBS-T buffer. Afterwards, sections were incubated with Alexa Fluor 488 and/or Alexa Fluor 568 secondary antibodies in humid Immunostaining tray for $30 \mathrm{~min}$ in dark to prevent quenching of fluorescence. After washing 3 times in TBS-T buffer, sections were mounted with cover slides containing Prolong Gold Antifade Reagent with DAPI (Life technologies). Slides were kept in dark at $4{ }^{\circ} \mathrm{C}$.

Images were acquired by Axioskop equipped with HBO 100 Microscope Illuminating System (Zeiss, Göttingen, Germany) and QiCam Fast 1394 Camera (Qimaging, Surrey, Canada), and SimplePCI software (Hamamatsu, Herrsching, Germany). 
Morphometric quantification of fluorescent signals was carried out with ImageJ program (National Institutes of Health, Bethesda, USA):

Briefly, image type of all pictures was first changed to 8-bit. After adjusting the threshold of image the percentage of fluorescently labeled area out of the tissue scetion was determined.

A detailed information about antibodies, dilutions and buffers/ solutions used in this study can be found in chapter 2.1.2 and 2.1.4.

\subsubsection{Hepatic hydroxyproline Assay}

4-hydroxyproline (hydroxyproline) is a posttranslationally modified amino acid characteristic of collagen. Due to its high specificity for collagen, the measurement of hydroxyproline levels serves as an indicator of collagen amount in the sample. Therefore, hepatic hydroxyproline assay was used to evaluate the extent of collagen deposition in our samples as previously published [148-149].

Generally, the whole process consists of three main steps: 1) Hydrolysis of sample with strong acid or alkali; 2) Oxidation of released hydroxyproline by buffered chloramines-T; 3 ) Development of chromophore by Ehrlich's reagent and detection colorimetrically or fluorimetrically. To that end, frozen liver tissue kept in liquid nitrogen was homogenized in $800 \mu \mathrm{l}$ of distilled water, and the lysate was hydrolyzed in $400 \mu \mathrm{l} 6 \mathrm{M} \mathrm{HCl}$ overnight in sand bath at $110^{\circ} \mathrm{C}$. After filtration of hydrolyzed lysate with Amicon Ultra-0.5 Centrifugal Filter Devices (Millipore, Darmstadt, Germany), filtered solution was evaporated by speed vacuum centrifugation (Eppendorf, Hamburg, Germany). Trans-4hydroxy-L-proline standard serial solutions were prepared in $50 \mu \mathrm{l}$ of distilled water: $0 \mu \mathrm{g}$, $0,5 \mu \mathrm{g}, 1,25 \mu \mathrm{g}, 2,5 \mu \mathrm{g}, 5 \mu \mathrm{g}, 10 \mu \mathrm{g}$ and $20 \mu \mathrm{g}$. At the same time, sediments from each sample were dissolved in $50 \mu 1$ of distilled water. $450 \mu 1$ of $56 \mathrm{mM}$ chloramines-T in acetate-citrate buffer ( $\mathrm{pH}$ 6,5) was added to standard and sample solutions and the solutions were incubated at room temperature for $25 \mathrm{~min}$. Then, another $500 \mu 1$ Ehrlich solution was added to standard and sample solutions and the solutions were incubated at $65^{\circ} \mathrm{C}$ for $20 \mathrm{~min}$. Finally, the solutions were transferred into UV cuvettes (Brand) and absorbance values were detected by Beckman DU640 Spectrophotometer (Beckman 
Coulter) at $562 \mathrm{~nm}$. Hydroxyproline level was measured based on standard curve, and normalized to liver tissue weight as $\mathrm{ng} / \mathrm{g}$ liver tissue.

\subsubsection{Bile flow assay}

Measurement of bile flow and bile composition was performed by our collaborators in the Division of Gastroenterology and Hepatology, Medical University Graz as described previously [122]. Briefly, the analysis was carried out in 4-month-old DDC-fed K19 KO and WT mice as well as age- and sex- matched animals on normal diet. Mice that were fasted overnight but had free access to water were anesthetized (10 $\mathrm{mg}$ of avertin intraperitoneally), and the gallbladder was cannulated after common bile duct ligation for collection of bile. After a 5-minute equilibration period, bile was collected in preweighed test tubes under mineral oil for 30 minutes, and bile flow was determined gravimetrically (assuming a density of $1.0 \mathrm{~g} / \mathrm{ml}$ ) and normalized to liver weight.

Given that DDC-induced protoporphyrin plugged the cannules, we were able to measure only bile composition but not flow rate in DDC-fed mice.

Biliary phospholipid concentration was determined using the commercial Phospholipid B kit (Wako, Neuss, Germany). Biliary cholesterol concentration was determined using the commercial Cholesterol Liquicolor kit (Human, Wiesbaden, Germany). Biliary bile acids concentrations were determined using the $3 \alpha$-hydroxysteroid dehydrogenase assay Kit (DiaSys, Holzheim, Germany) according to the manufacturer's instructions. Biliary bicarbonate was measured with AVL 995 automatic blood gas analyzer (AVL, Graz, Austria).

\subsubsection{Microarray}

To further explore the importance of K19 in DDC-fed livers, cDNA microarray analysis was performed at Chip-Facility of University Medical Centre Ulm. To that end, total RNA was isolated from DDC-fed WT and K19 KO mouse livers (five per group) using RNeasy Mini Kit (Qiagen). 


\subsubsection{Microarray analysis}

Microarray analyses were performed using $200 \mathrm{ng}$ total RNA as starting material. Total RNA was amplified and labeled using the Whole Transcript (WT) Sense Target Labeling Assay (http://www.affymetrix.com). $5.5 \mu \mathrm{g}$ of labeled ssDNA was hybridized to Mouse Gene 1.0 ST Affymetrix GeneChip arrays (Affymetrix) with the help of GeneChip Fluidics Station 450 (Affymetrix, Santa Clara, USA). The chips were scanned with an Affymetrix GeneChip Scanner 3000 and subsequent images analysis was performed with Affymetrix ${ }^{\circledR}$ Expression Console ${ }^{\mathrm{TM}}$ Software (Affymetrix). A transcriptome analysis was carried out using BRB-ArrayTools developed by Dr. Richard Simon and the BRB-ArrayTools Development Team (http://linus.nci.nih.gov/BRB-ArrayTools.html). Raw data were normalized, and $\log _{2}$ intensity expression summary values for each probe set were calculated using robust multiarray average (RMA) [150].

Genes showing minimal variation across the set of arrays were excluded from the analysis which genes whose expression differed by at least 1.5 fold from the median in at least $20 \%$ of the arrays were further investigated.

To identify genes which are differentially expressed among the two classes, a 2 sample ttest was used. Genes were considered statistically significant if their $p$ value was less than 0.05 and displayed an at least 1.5 fold change.

\subsubsection{Gene Ontology analysis}

To identify the most affected biological processes, as defined by Gene Ontology annotation GO, we used the GoMINER analysis tool [151]. This package allows the automatic analysis of multiple microarrays and then integrates the results to find the GO categories that were significantly $(\mathrm{p}<0.05)$ over- or under-represented. Only genes with a 1.5 -fold up- or down-regulation were included in the analysis. 


\subsubsection{Statistics}

Data are shown as mean \pm standard error of the mean (SEM). For normally distributed samples, parametrical paired two-tailed Student's t-test was performed, while nonparametrical Mann-Whitney U-test was used for samples without normal distribution. A pvalue below 0.05 was considered statistically significant. Statistical Package for the Social Sciences (SPSS) software version 15.0.1(IBM, New York, USA) was used in this study. 


\section{Results}

\subsection{Characterization of role of Keratin 19 under basal conditions}

\subsubsection{Confirmation of genotyping at protein level}

Genotyping of WT and K19-KO mice was performed by PCR as described previously [55]. WB and IF with the troma-III antibody further confirmed the genotyping of the animals, while 3 -actin demonstrated equal protein contents of the liver lysates (Figure 3a). Of note, K19 was mainly peripherally distributed within cholangiocytes (Figure 3b).

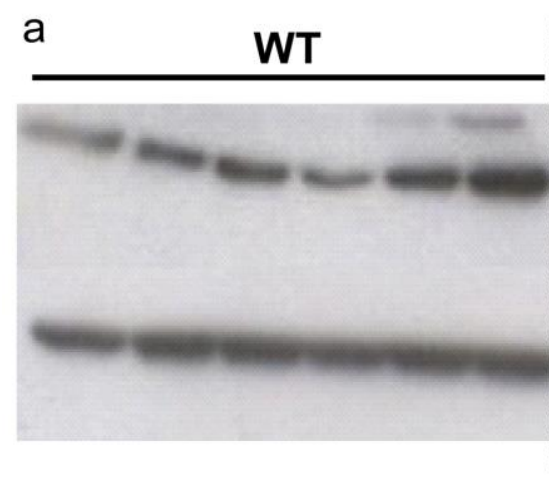

b

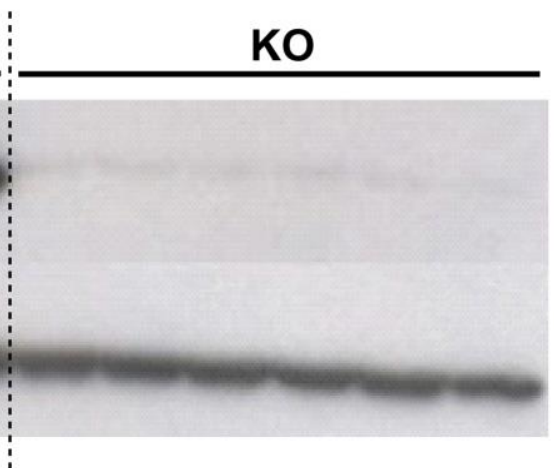

KO

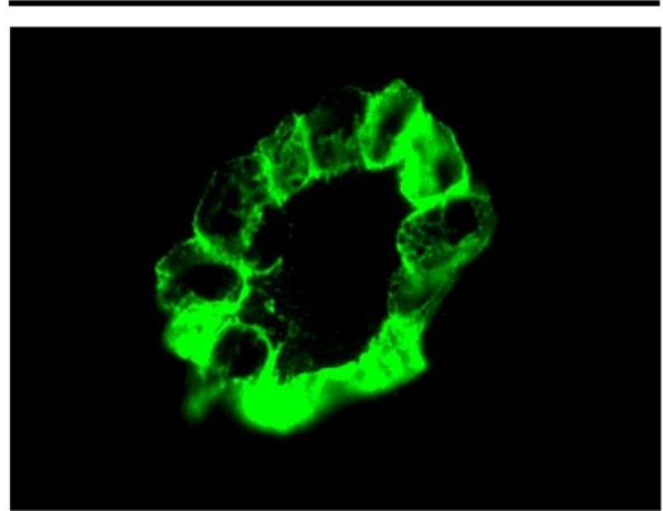

keratin 19

\section{$\beta$-actin}

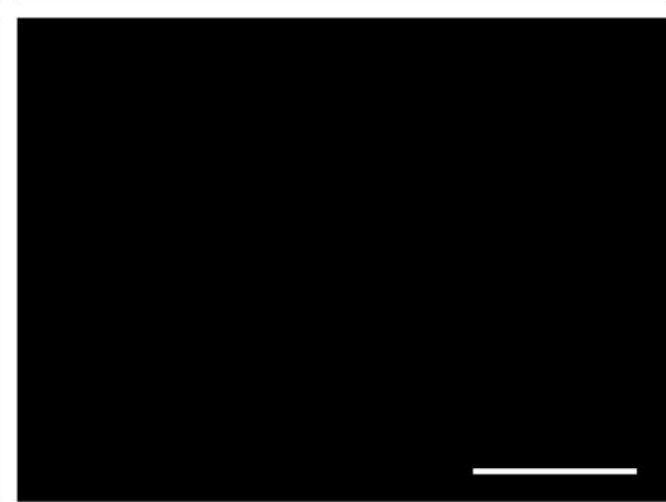

Figure 3. Confirmation of keratin 19 knockout (K19-KO) genotyping at protein level. (a) Western blot with the troma-III antibody was performed in total liver lysates with $\beta$-actin being used as a loading control. (b) Fluorescent signal (green) visualizes K19 fluorescence in K19-wildtype (WT) but not K19-KO cholangiocytes. Note that K19 displays a predominantly peripheral distribution in cholangiocytes. Scale bar in (b) $=25 \mu \mathrm{m}$. 


\subsubsection{Analysis of keratin gene expression in digestive system of K19-KO and -WT} mice

In order to investigate keratin expression at mRNA level, quantitative real-time RT-PCRs were carried out in liver, CBD, GB and colon samples (Figure 4). As expected, K19 expression is absent in tissues of K19-KO animals, and K19 levels were the highest in GB and colon. The expression of the other keratins (K7, K8, K18) within digestive system was not altered by loss of K19, with the only exception being K18 mRNA in colon, that significantly increased to compensate for the K19 loss.

a

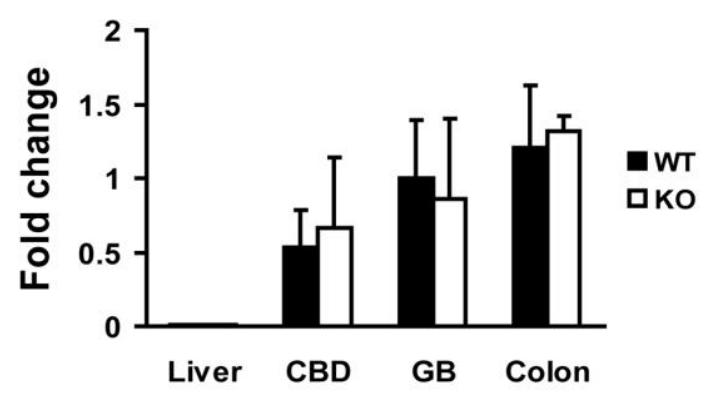

C

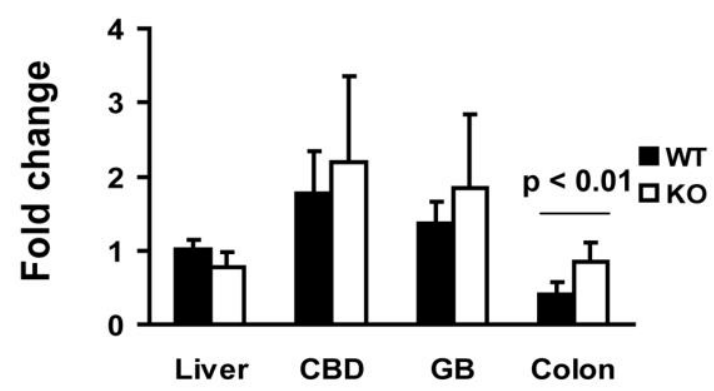

b

\section{K8 mRNA}

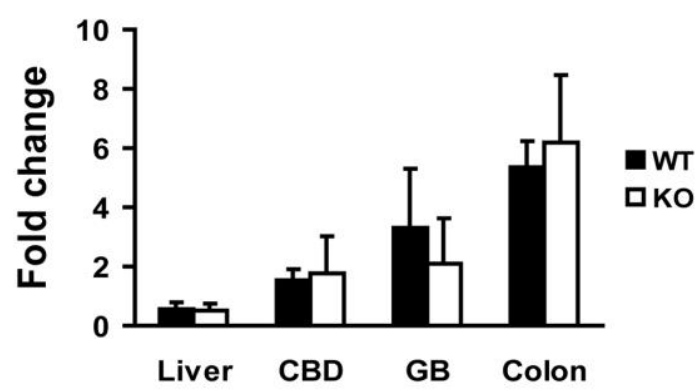

d

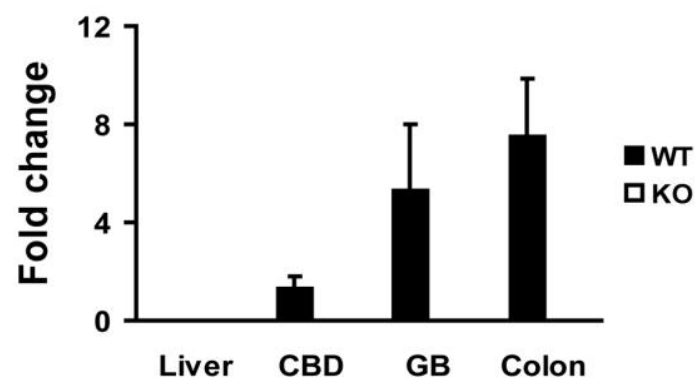

Figure 4. Keratin expression in digestive epithelia. Keratin (K) 7/8/18/19 gene expressions were assessed in liver, common bile ducts (CBD), gallbladders (GB) and colons from 2-month-old females by quantitative real-time RT-PCR. Similar keratin mRNA levels were observed in K19 wild-type (WT) and knockout (KO) animals except the elevated K18 mRNA levels in colons of K19-KOs.

\subsubsection{K19 loss leads to alteration of keratin distribution}


To test whether loss of K19 leads to keratin redistribution within intrahepatic bile ducts (IHBDs), we performed IF staining. Type I keratins (K18 and K19) exhibited predominantly a non-polarized staining within cholangiocytes while type II keratins (K7 and K8) were preferentially apically distributed. In the absence of K19, however, K7 and $\mathrm{K} 8$ redistributed from a predominantly apical staining to a non-polarized cytoplasmic localization (Figure 5), indicating that type II keratins compensate the loss of K19 by altering their distribution. Morphometric quantification (Figure 6) confirmed the keratin distribution pattern shown in Figure 5.

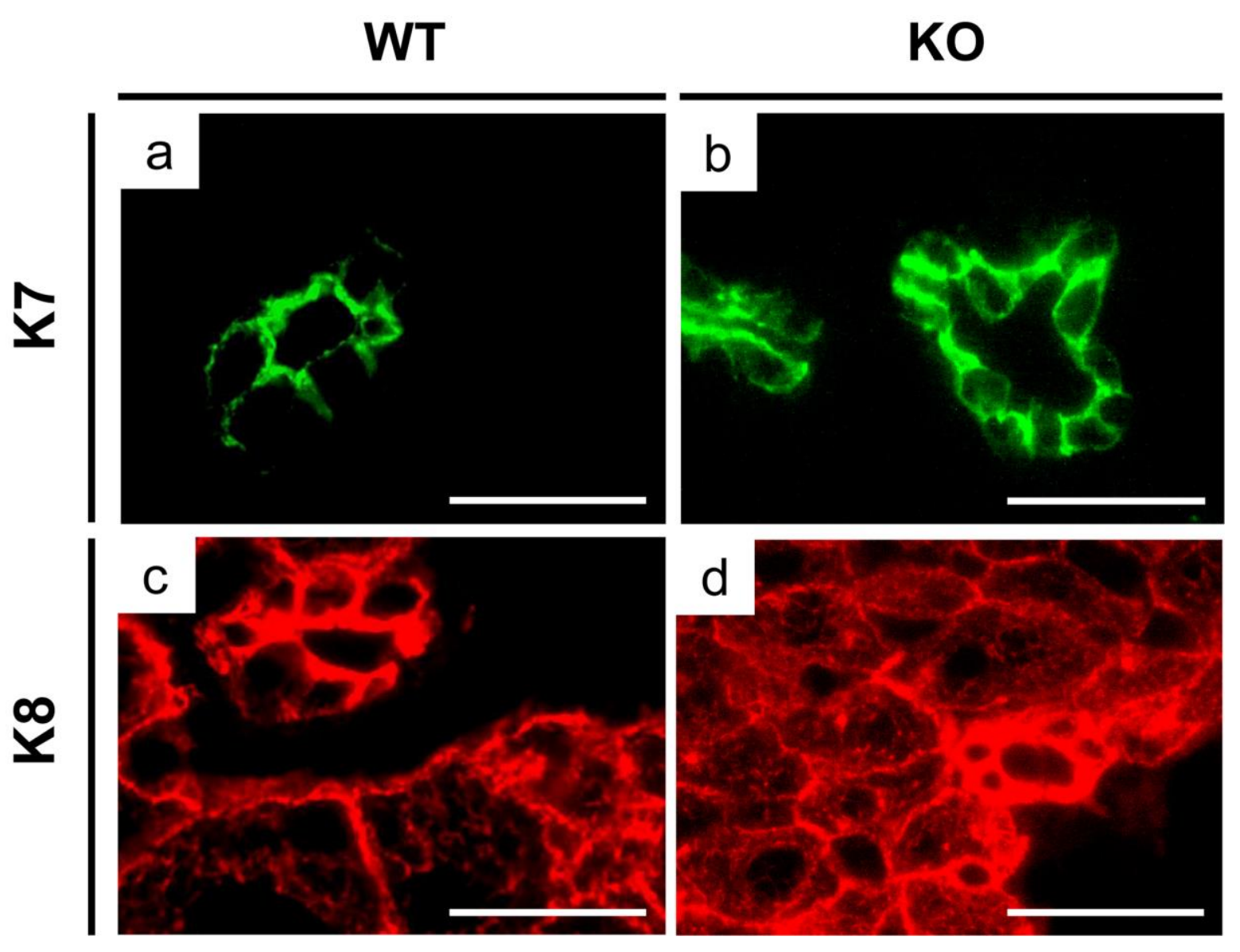

Figure 5. Immunofluorescence (IF) staining of keratin (K) 7 and K8 in untreated livers. IF staining for Keratin (K)7 and K8 demonstrates that the loss of K19 leads to redistribution of K7 and K8 within intrahepatic bile ducts (IHBDs) from a more apical to more cytoplasmic non-polarized staining. Scale bar $=$ $25 \mu \mathrm{m}$. 


\section{K distribution}

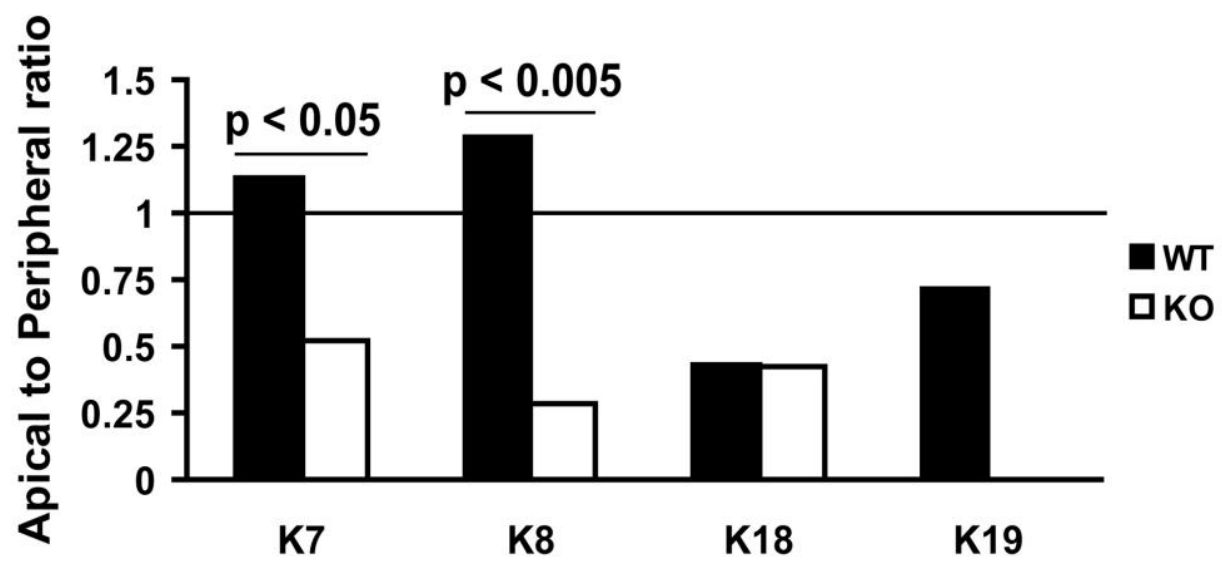

Figure 6. Quantification of keratin distribution. Morphometric quantification was performed to determine the ratio of intrahepatic bile ducts (IHBDs) with the predominantly apical vs. the non-polarized keratin distribution and confirms the altered Keratin (K) 7 and K8 staining pattern found in K19-KO IHBDs.

\subsubsection{K19-KO mice display largely normal biliary function under basal condition}

Since biliary cytoskeleton contributes to a proper targeting of bile transporter proteins [152], we wondered whether k19 loss affects biliary physiology. To find this out, bile flow and output of major bile constituents were measured, but no substantial alterations were observed (Figure 7 and Figure 8). These data suggest that unstressed K19-KO mice displayed largely normal biliary epithelia in spite of a re-arrangement of biliary keratins towards a more cytoplasmic localization.

Bile flow assay

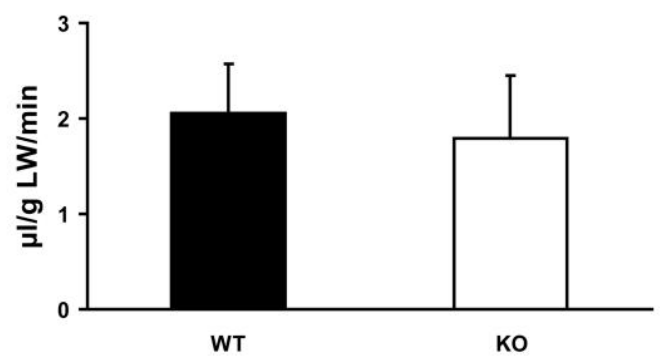

Figure 7. Bile flow quantification in untreated keratin 19 knockout (K19-KO) and wildtype (WT) mice. Comparable bile flow rates indicate that K19 loss didn't affect the bile formation and clearance. 


\section{Biliary physiology}

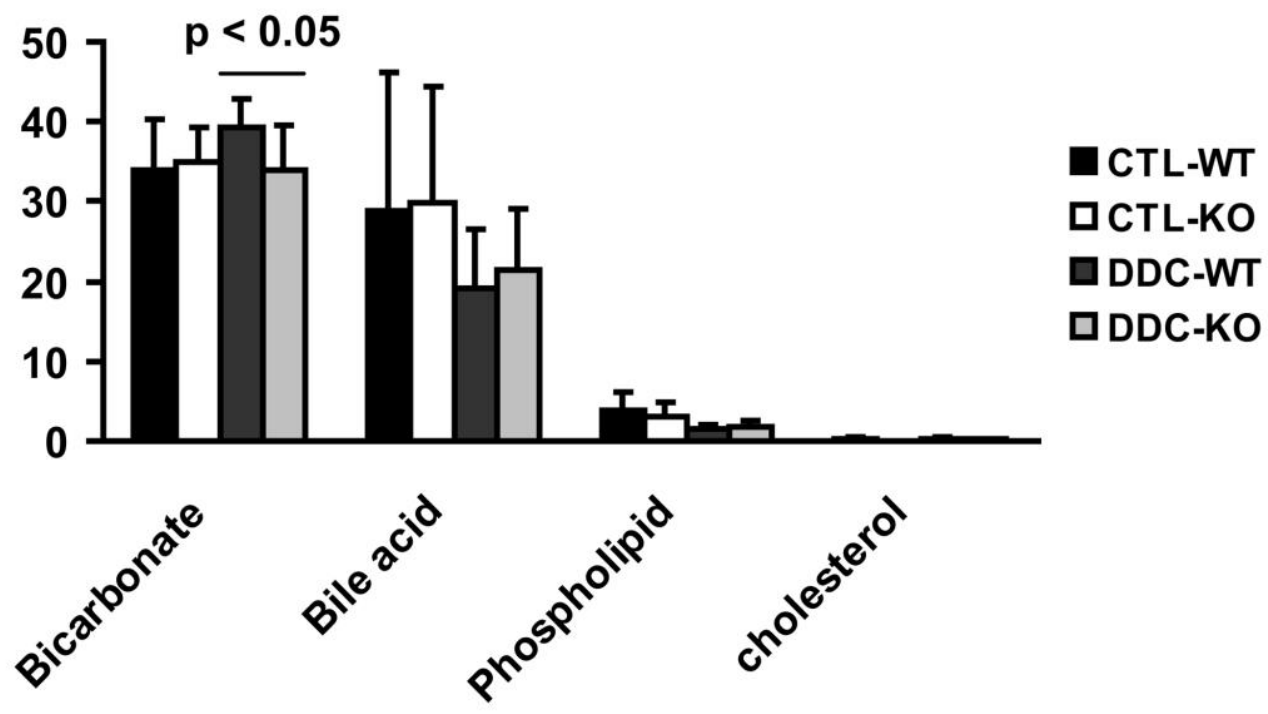

Figure 8. Output of major bile constituents in keratin 19 knockout (K19-KO) and wildtype (WT) animals. Bile composition didn't differ between untreated (CTL) K19-KOs and WTs, however, significantly decreased bicarbonate output was detected in DDC-fed K19-KOs when compared to DDC-fed WT animals.

\subsection{K19-KO mice suffer more severe biliary injury after chronic DDC administration}

\subsubsection{Loss of K19 causes stronger cholestatic liver injury after 4-week DDC feeding}

To assess the function of biliary K19 under stress conditions, 4-week DDC feeding was used since it has previously been shown to constitute an established mouse model of chronic cholestatic liver diseases [124], as well as a model of oval cell activation [107].

Though the DDC treatment was well-tolerated and no lethality was observed, K19-KO mice displayed a trend towards higher body weight loss (not shown). Chronic DDC administration led to a marked liver hypertrophy in both WT and K19-KO animals, with a significant elevation of cholestatic indicators and ALT level. No difference in hepatic injury markers and the extent of liver hypertrophy was seen between the genotypes. On the other hand, K19-KO mice developed a stronger cholestasis as evidenced by increased 
serum bilirubin ( $157 \pm 72$ vs. $34 \pm 44$ in WT, p < 0,01), serum bile acids ( \pm 79 vs $339 \pm 55$, $\mathrm{p}<0,01)$ and ALP levels (883 \pm 125 vs $637 \pm 172, \mathrm{p}<0,05)$ (Figure 9).

\section{Serum biochemistry}

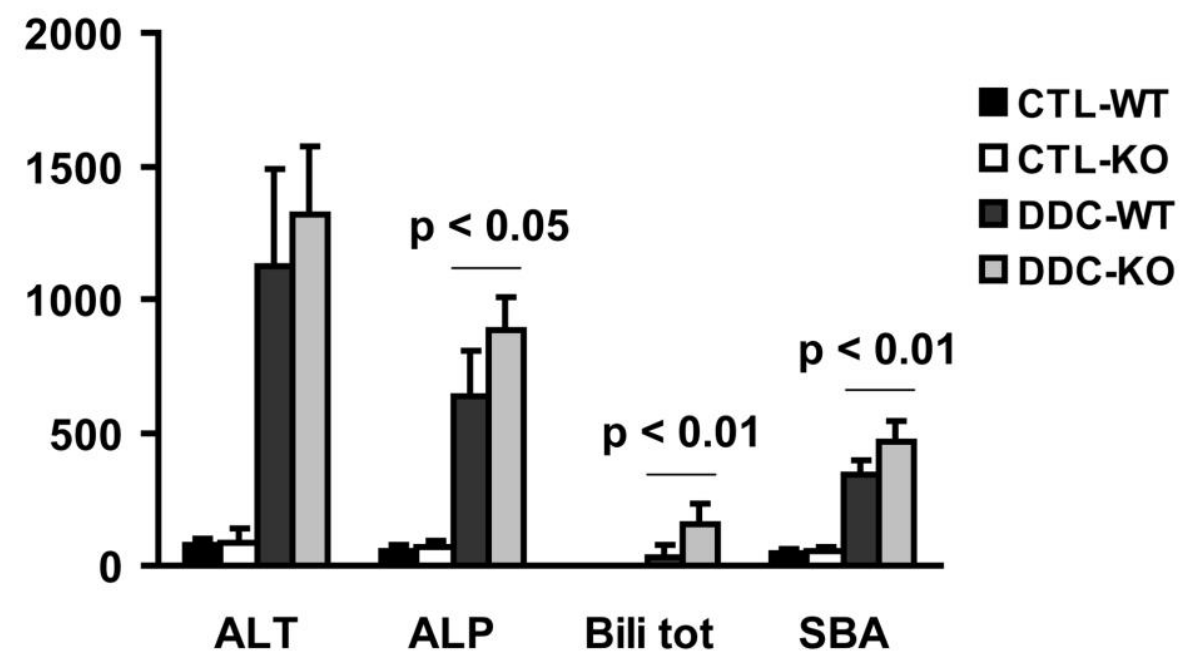

Figure 9. Serum biochemical analysis of control (CTL) and DDC-treated animals. Loss of keratin (K) 19 is well compensated under basal condition (CTL), but K19 knockout (KO) mice exhibited a stronger cholestatic injury evidenced by elevated biliary injury cholestasis markers such as alkaline phosphatase (ALP), serum bile acid (SBA) and total bilirubin (Bili tot) after feeding with 3, 5-diethoxycarbonyl-1,4dihydrocollidine (DDC).

\subsubsection{Loss of K19 results in a higher extent of biliary obstruction after 4-week DDC feeding}

DDC represents a porphyrinogenic drug which has been shown to cause formation of porphyrin gallstones [124]. To study whether a difference in the stones formation may contribute to the stronger cholestatic injury seen in K19-KOs, we performed morphometrical quantification from DDC-fed livers revealed exacerbated extent of obstructed IHBDs in the portal area owing to the accumulation of porphyrin pigments $(50 \% \pm 4,5 \%$ vs $38 \% \pm 7,3 \%, p<0,005)$ (Figure 10 and Table 22), supporting the increased total bilirubin levels in the serum. 

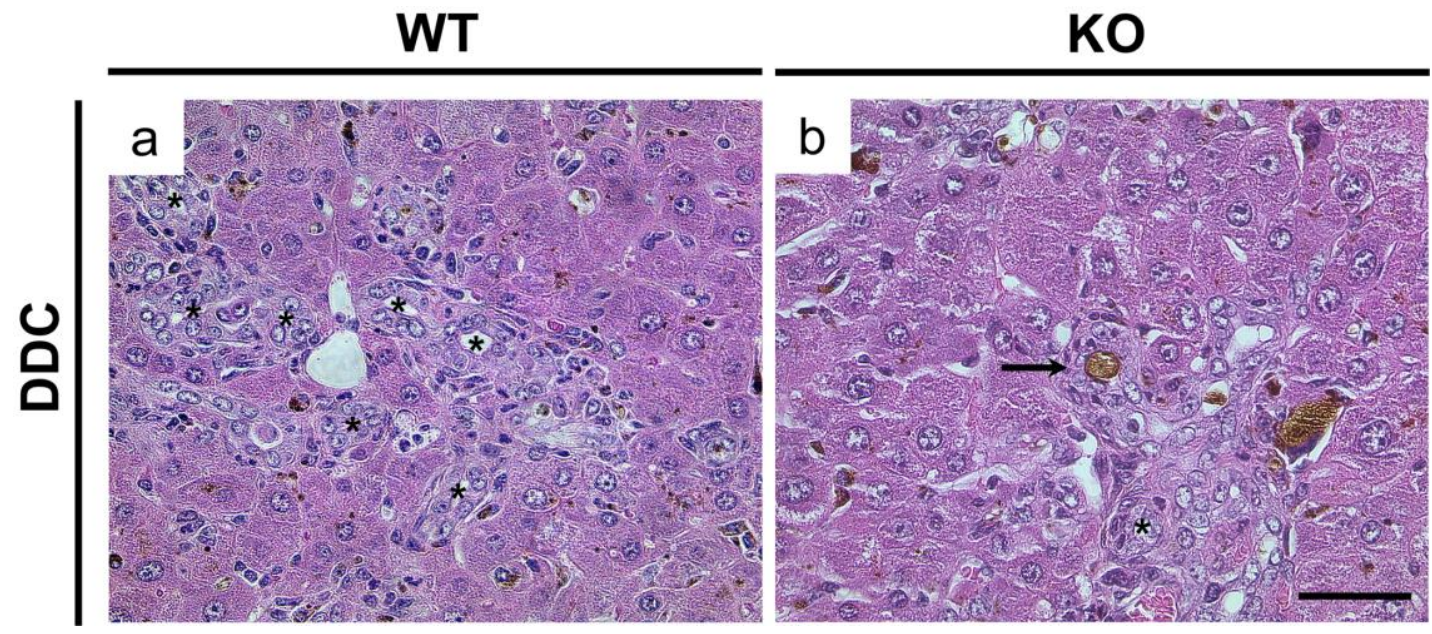

Figure 10. H\&E staining of 4w-DDC-fed (DDC) livers. H\&E staining of DDC-fed mice showed the K19 loss resulted in increased biliary obstruction. Asterisks in a) mark the open bile lumina, while arrowheads in b) highlight plugged bile ducts. Scale bar $=50 \mu \mathrm{m}$.

Table 22. Histological analysis.

\begin{tabular}{|c|c|c|c|c|}
\hline & \multicolumn{2}{|c|}{ Control } & \multicolumn{2}{|c|}{ DDC } \\
\hline & WT $(n=6)$ & KO $(n=5)$ & WT $(\mathbf{n}=8)$ & KO $(n=7)$ \\
\hline Ductular reaction (Stage) & $\mathbf{0} \pm \mathbf{0}$ & $\mathbf{0} \pm \mathbf{0}$ & $1.9 \pm 0.4^{\mathrm{a}}$ & $1.4 \pm 0.3^{\mathrm{a}}$ \\
\hline Biliary obstruction (\%) & & & $38 \pm 7.3^{\mathrm{b}}$ & $50 \pm 4.5^{\mathrm{b}}$ \\
\hline BEC mitotic rate (\%) & $3.7 \pm 6.3$ & $3.4 \pm 5.4$ & $18.2 \pm 4.2^{\mathrm{c}}$ & $8.6 \pm 1.2^{\mathrm{c}}$ \\
\hline Biliary apoptosis (\%) & $\mathbf{0} \pm \mathbf{0}$ & $\mathbf{0} \pm \mathbf{0}$ & $2.8 \pm 1.0$ & $4.7 \pm 1.9$ \\
\hline Fibrosis (Stage) & $\mathbf{0} \pm \mathbf{0}$ & $\mathbf{0} \pm \mathbf{0}$ & $3 \pm 0^{d}$ & $2.4 \pm 0.5^{\mathrm{d}}$ \\
\hline
\end{tabular}

DDC, 3,5-diethoxycarbonyl-1 ,4-dihydrocollidin; BEC, biliary epithelial cell. KO, keratin 19 knockout; WT, keratin 19 wild type.

${ }^{\mathrm{a}} \mathrm{p}<0.05 ;{ }^{\mathrm{b}} \mathrm{p}<0.005 ;{ }^{\mathrm{c}} \mathrm{p}<0.005 ;{ }^{\mathrm{d}} \mathrm{p}<0.05$.

To test whether differences in porphyrin metabolism are responsible for the stronger biliary obstruction in DDC-fed K19-KOs, we performed porphyrin assay. However, comparable PPIX (Figure 11) levels excluded the above possibility. 


\section{Protoporphyrin IX}

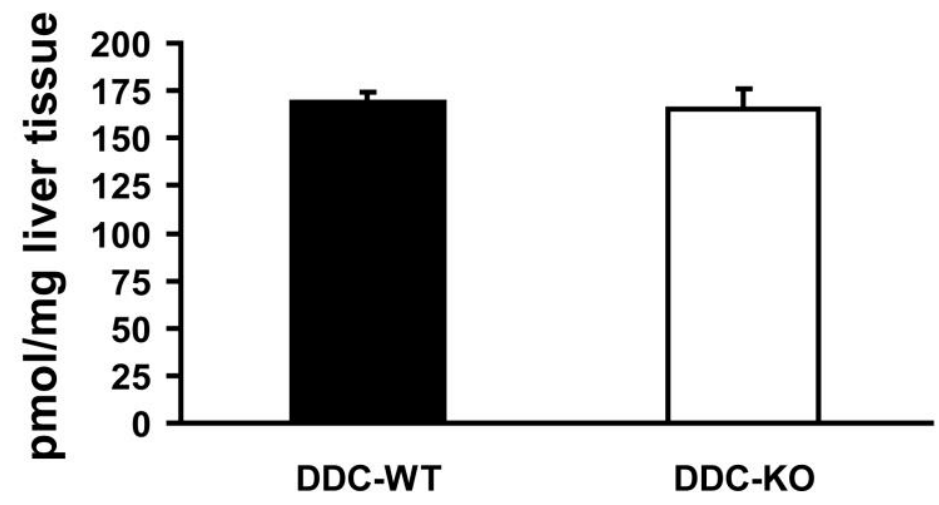

Figure 11. Porphyrin levels in 4 weeks DDC-fed livers. Porphyrin assay revealed no difference in accumulation of porphyrin between DDC-fed keratin 19 knockouts (K19-KOs) and wildtypes (WTs).

\subsubsection{Loss of K19 results in decreased biliary bicarbonate levels after chronic DDC treatment}

Because of the aggravated biliary injury in DDC-fed K19-KO livers, we investigated whether bile production process is affected by the loss of K19.

While DDC feeding significantly reduced the biliary bicarbonate output, the overall bile composition was similar in DDC-fed K19-WT and -KO animals (Figure 8).

\subsubsection{Loss of K19 leads to altered gene expression after 4-week DDC feeding}

To obtain a comprehensive overview of the importance of K19 in DDC-induced cholestatic liver injury, cDNA microarray analysis was performed with total liver RNAs from DDCfed animals (Figure 12). It revealed that K19 loss resulted in altered gene expression after DDC challenge. The observed changes involved genes participating in gluconeogenesis [153-155], mitochondrial homeostasis and metabolism [156-158], cell growth [159], bile production [160-161], and bile secretion [162]. For details see Table 23. Quantitative real time RT-PCR confirmed the observed differences (Table 23). 


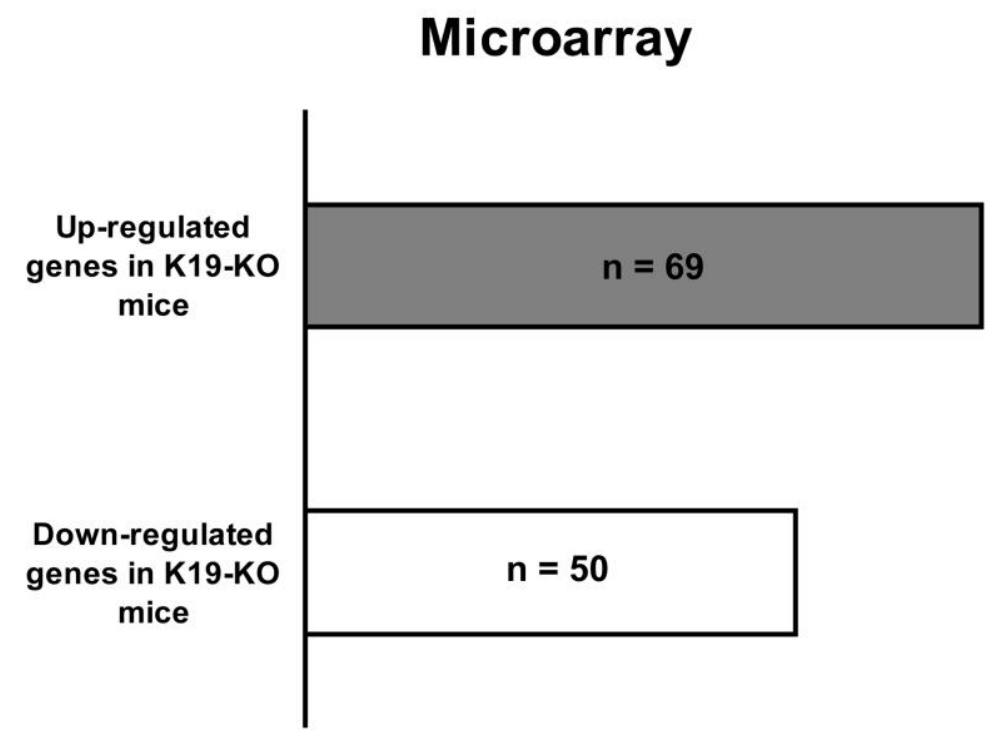

Figure 12. cDNA microarray of DDC-fed livers. Loss of Keratin (K) 19 led to changes in gene expression in the livers of DDC-treated animals.

Table 23. Selected differentially expressed genes in mice chronically fed with DDC.

\begin{tabular}{|c|c|c|c|c|c|}
\hline \multirow{2}{*}{ Genes } & \multicolumn{2}{|c|}{ RT-PCR } & \multicolumn{2}{c|}{ Microarray } & \multirow{2}{*}{ Function } \\
\cline { 2 - 6 } & Fold change & P value & Fold change & P value & \\
\hline Kcnj16 & 14,0 & 0.0006 & 2.6 & 0.0000002 & Regulation of pH balance [163-164] \\
\hline Pck1 & 3,6 & 0.02 & 3.11 & 0.0006 & Regulation of gluconeogenesis \\
\hline Ppargc1a & 2.0 & 0.008 & 1.8 & 0.001 & [153-155] \\
\hline Plk3 & 2.6 & 0.05 & 2,0 & 0.0002 & Inhibition of cell growth [159] \\
\hline Slco1a1 & 1,0 & 0.01 & 0.2 & 0.008 & Bile acid uptake in hepatocytes \\
\hline Sstr2 & 0.3 & 0.0000 & 0.4 & 0.000006 & Regulation of bile flow in BEC [162] \\
& & 1 & & & \\
\hline
\end{tabular}

KO, knockout; WT, wildtype 
Of note, the Somatostatin receptor type 2 (SSTR2) gene is expressed only in the basolateral membrane of cholangiocytes in liver and negatively regulates the bile flow through cholangiocytes [162].

\section{Sstr2 mRNA}

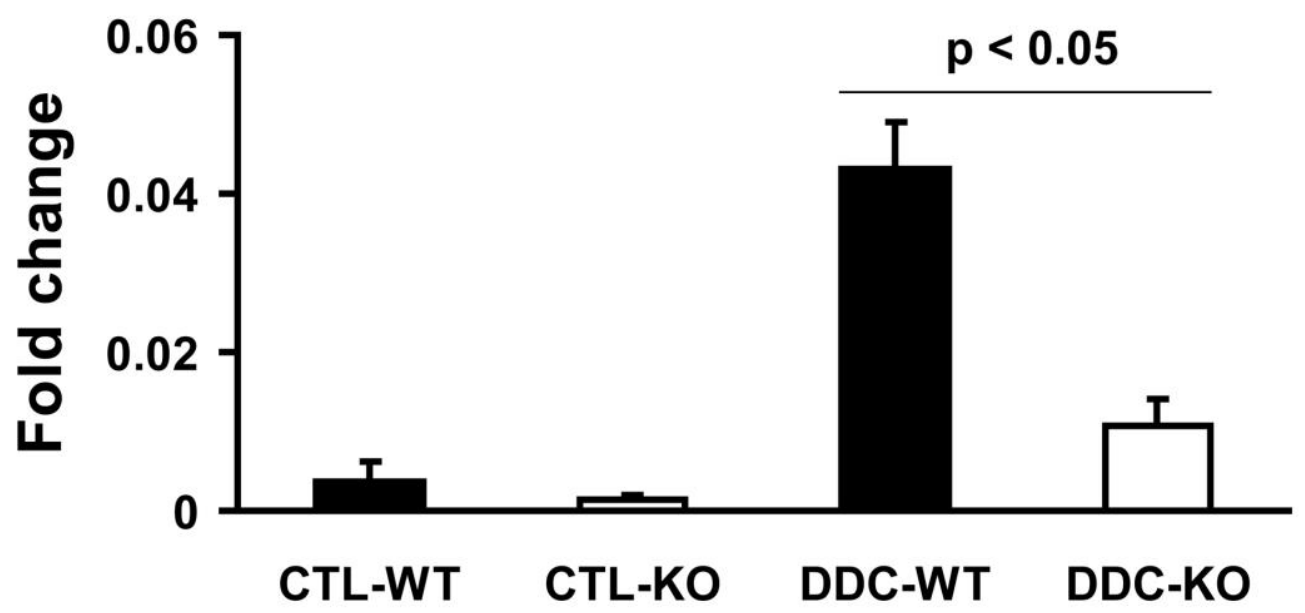

Figure 13. Somatostatin receptor type 2 (Sstr2) levels in keratin 19- wildtype (WT) and knockout (KO) animals. Quantitative real-time RT-PCR analysis reveals elevated hepatic Sstr2 mRNA expression in DDCfed versus control (CTL) animals. DDC-fed K19-KOs exhibit significantly lower sstr2 mRNA levels compared to DDC-fed WTs.

\subsection{DDC-fed K19-KO mice display weaker ductular reaction and biliary fibrosis}

\subsubsection{Loss of K19 reduces biliary regeneration after 4-week DDC treatment}

Since chronic DDC feeding results in massive ADP [123], we studied whether this phenomenon is affected by the absence of K19. Therefore, we performed histological quantification which demonstrated that DDC-fed K19 KOs display decreased ADP (Figure 14 and Table 22). 


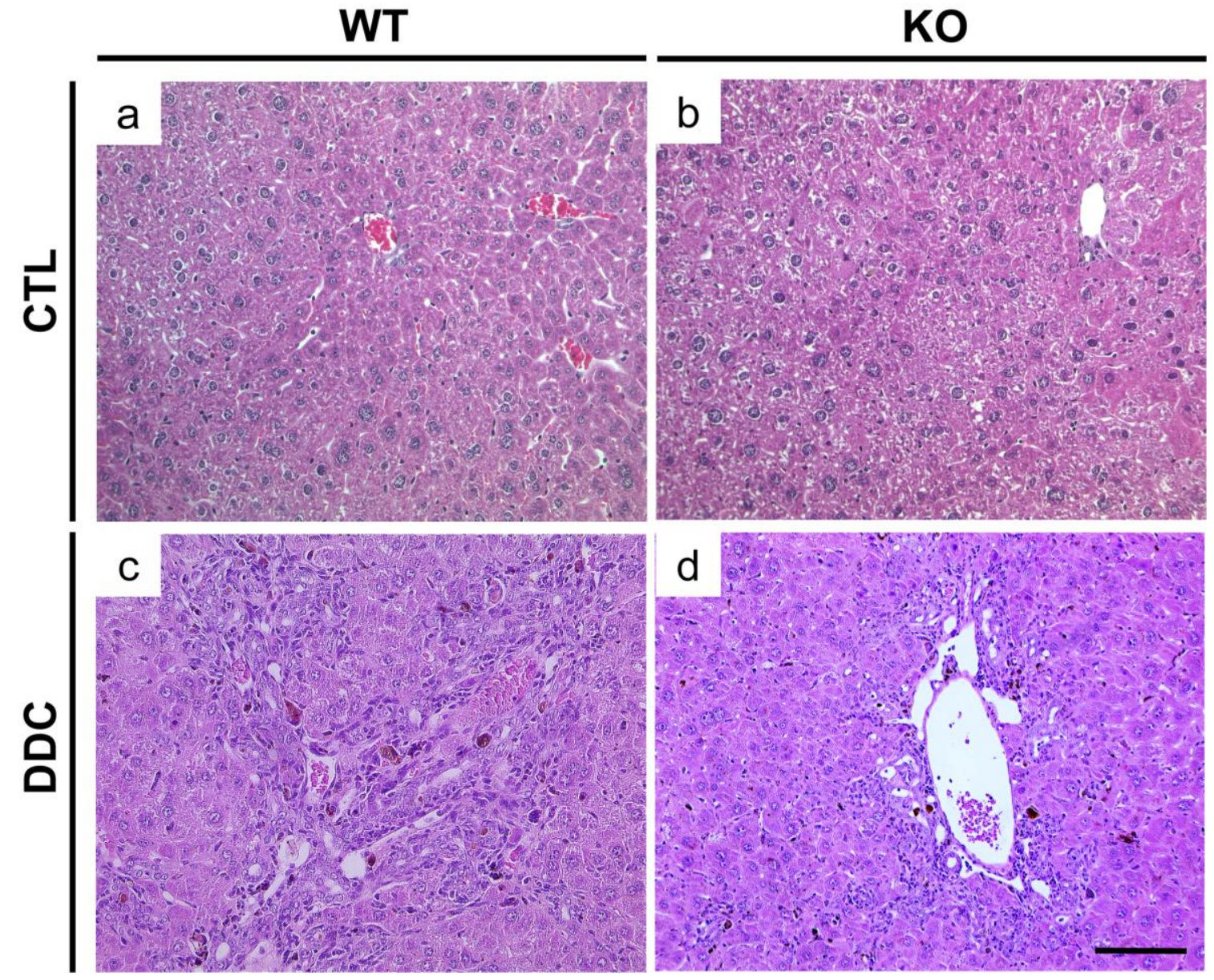

Figure 14. Hematoxylin and eosin (H\&E) staining of control (CTL) and 4w-DDC-fed (DDC) livers. H\&E staining of livers from CTL and DDC mice demonstrates that loss of K19 (KO) attenuates the DDCinduced ductular reaction. Scale bar $=100 \mu \mathrm{m}$.

In addition, we carried out pankeratin (panK) IF staining to visualize ductular cells. Consistently, loss of K19 resulted in lower amounts of panK-positive cells after 4-week DDC feeding (Figure 15 and Table 24). 

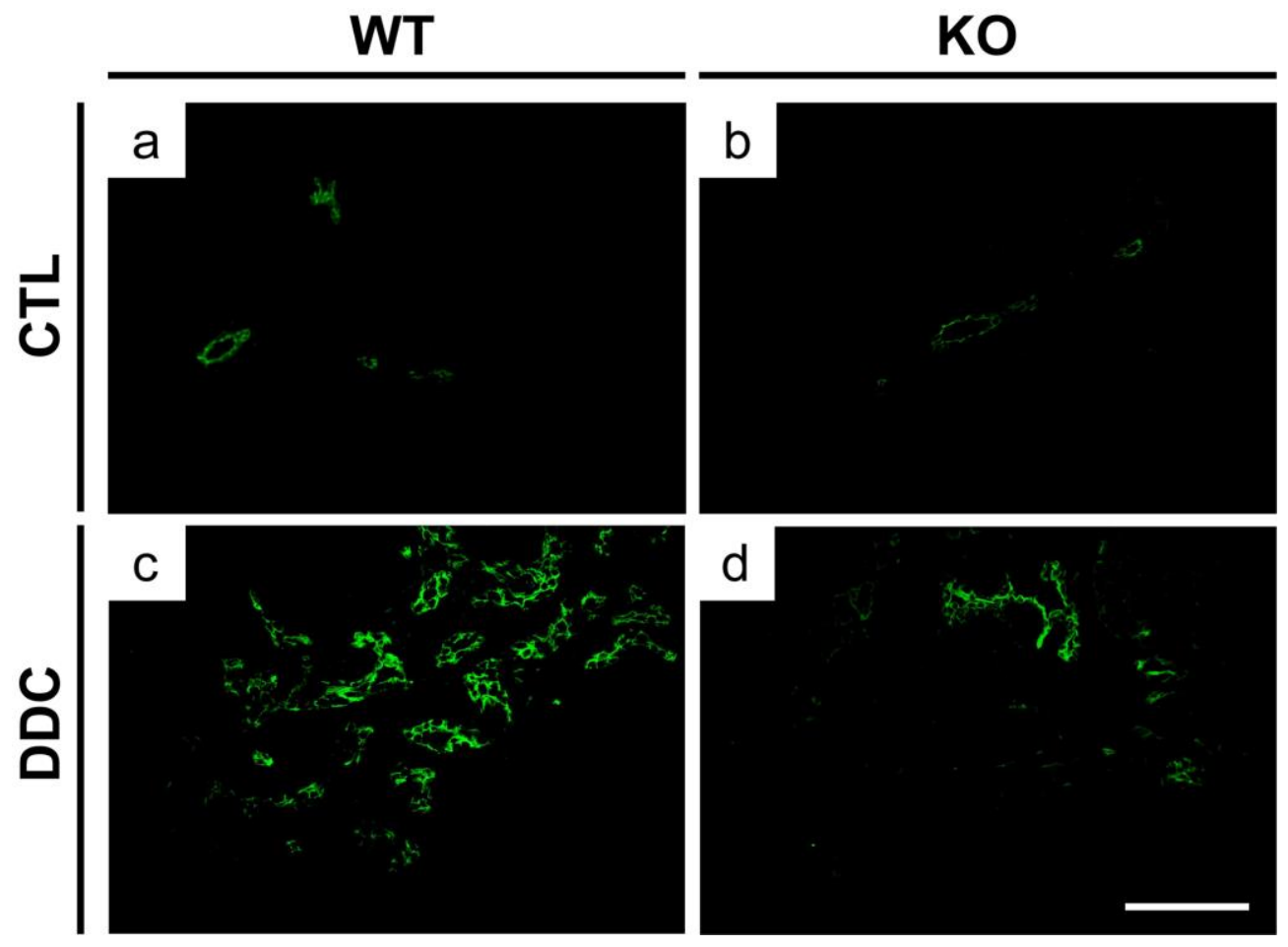

Figure 15. Immunofluorescence (IF) staining of pankeratin (panK) from control (CTL) and 4w-DDCfed (DDC) livers. IF staining of CTL and DDC livers shows a decreased amount of panK-positive cells in DDC-fed K19 knockouts (KOs) versus wildtypes (WTs). Scale bar $=100 \mu \mathrm{m}$.

Table 24. Morphometric analysis of DDC-treated mice.

\begin{tabular}{|c|c|c|c|c|}
\hline & \multicolumn{2}{|c|}{ Control } & \multicolumn{2}{|c|}{ DDC } \\
\hline & WT $(n=3)$ & KO $(n=3)$ & WT $(n=3)$ & $\mathrm{KO}(\mathrm{n}=3)$ \\
\hline Ductal cells (\%) & $0.2 \pm 0.1$ & $0.1 \pm 0.0$ & $6.8 \pm 0.8^{\mathrm{a}}$ & $1.3 \pm 0.9^{\mathrm{a}}$ \\
\hline $\mathrm{A6}^{+}$BECs (\%) & $0.2 \pm 0.03^{b}$ & $0.1 \pm 0.02^{b}$ & $3.2 \pm 0.52^{\mathrm{c}}$ & $1.6 \pm 0.27^{\mathrm{c}}$ \\
\hline Notch $2^{+}$BECs (\%) & $33 \pm 3.1$ & $29 \pm 5.0$ & $49 \pm 7.4^{d}$ & $29 \pm 1.8^{d}$ \\
\hline
\end{tabular}

DDC, 3,5-diethoxycarbonyl-1 ,4-dihydrocollidin; BEC, biliary epithelial cell. KO, keratin 19 knockout; WT, keratin 19 wild type.

${ }^{\mathrm{a}} \mathrm{p}<0.005 ;{ }^{\mathrm{b}} \mathrm{p}<0.05 ;{ }^{\mathrm{c}} \mathrm{p}<0.05 ;{ }^{\mathrm{d}} \mathrm{p}<0.05$.

\subsubsection{Loss of K19 reduces DDC-induced proliferation of cholangiocytes}


Reduced ADP in DDC-fed K19-KO livers led us to evaluate the proliferation of cholangiocytes. The rate of proliferating biliary cells per IHBD was calculated based on Ki-67 IHC staining (Figure 16). While chronic DDC administration induced a profound increase in biliary proliferation, the DDC-induced regeneration of biliary epithelium was attenuated by loss of $\mathrm{K} 19(18,2 \% \pm 4,2 \%$ vs $8,6 \% \pm 1,2 \%$, p < 0,005, Table 22$)$.

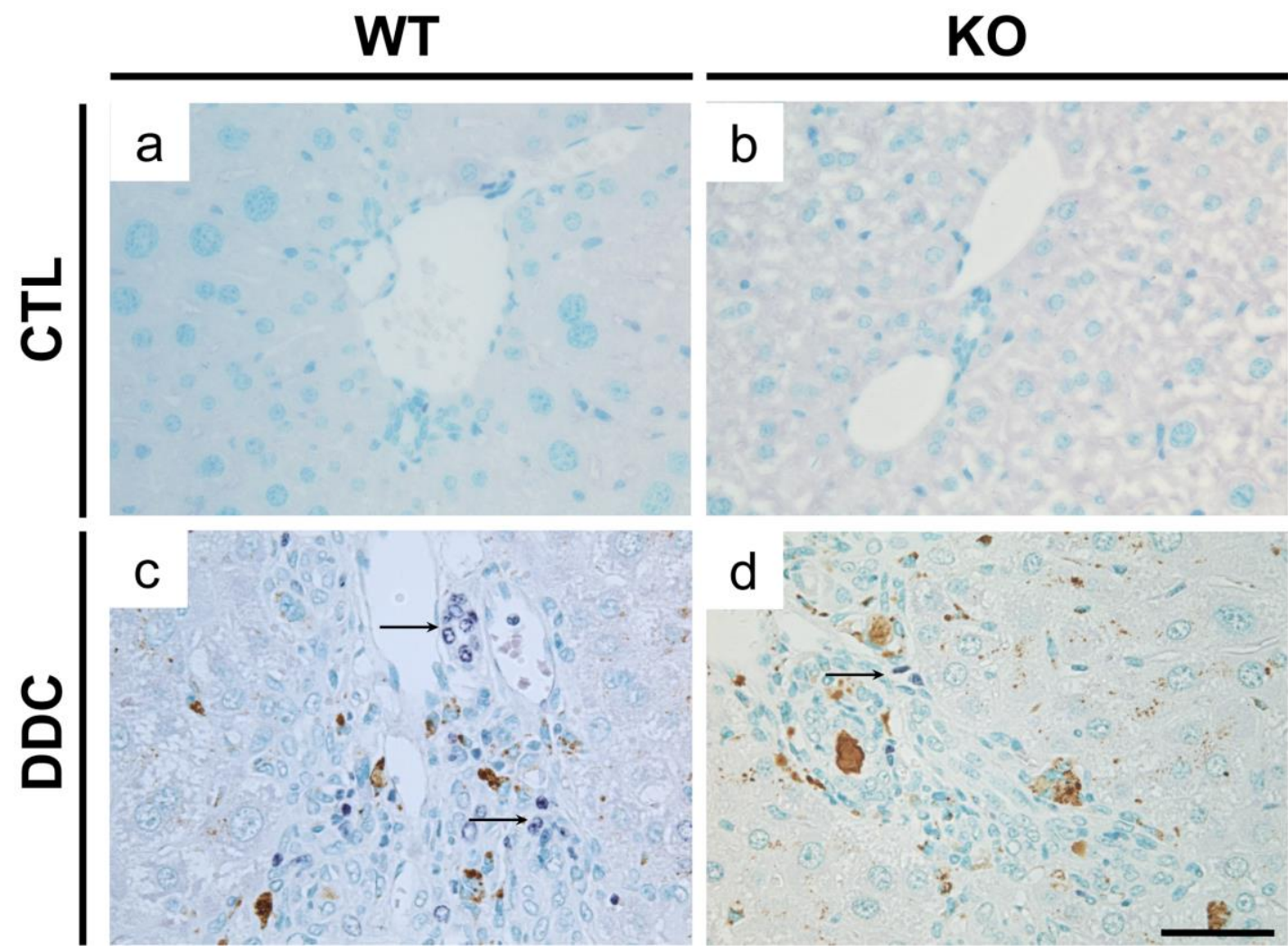

Figure 16. Immunohistochemistry (IHC) staining of Ki67 in control (CTL) and 4w-DDC-fed (DDC) livers. IHC staining for the proliferation marker Ki67 (in purple color) reveals that the extent of DDC induced proliferation of ductal structures is weaker in DDC-treated Keratin 19 knockouts (K19-KOs) (KO) versus -wildtype (WT) animals. Scale bar $=50 \mu \mathrm{m}$.

To further explore whether DDC-induced biliary apoptosis contributes to the observed weaker ADP in K19-KO livers, we measured the rate of ductal apoptosis per IHBD by means of D237 IHC staining with subsequent morphometric quantification. Although mild apoptosis was seen in biliary epithelium after chronic DDC treatment (Figure 17), no difference was found between K19-WTs and -KOs $(2,8 \% \pm 1,0 \%$ vs 4,7 \% $\pm 1,9 \%$, p > 0,05 , Table 22). 


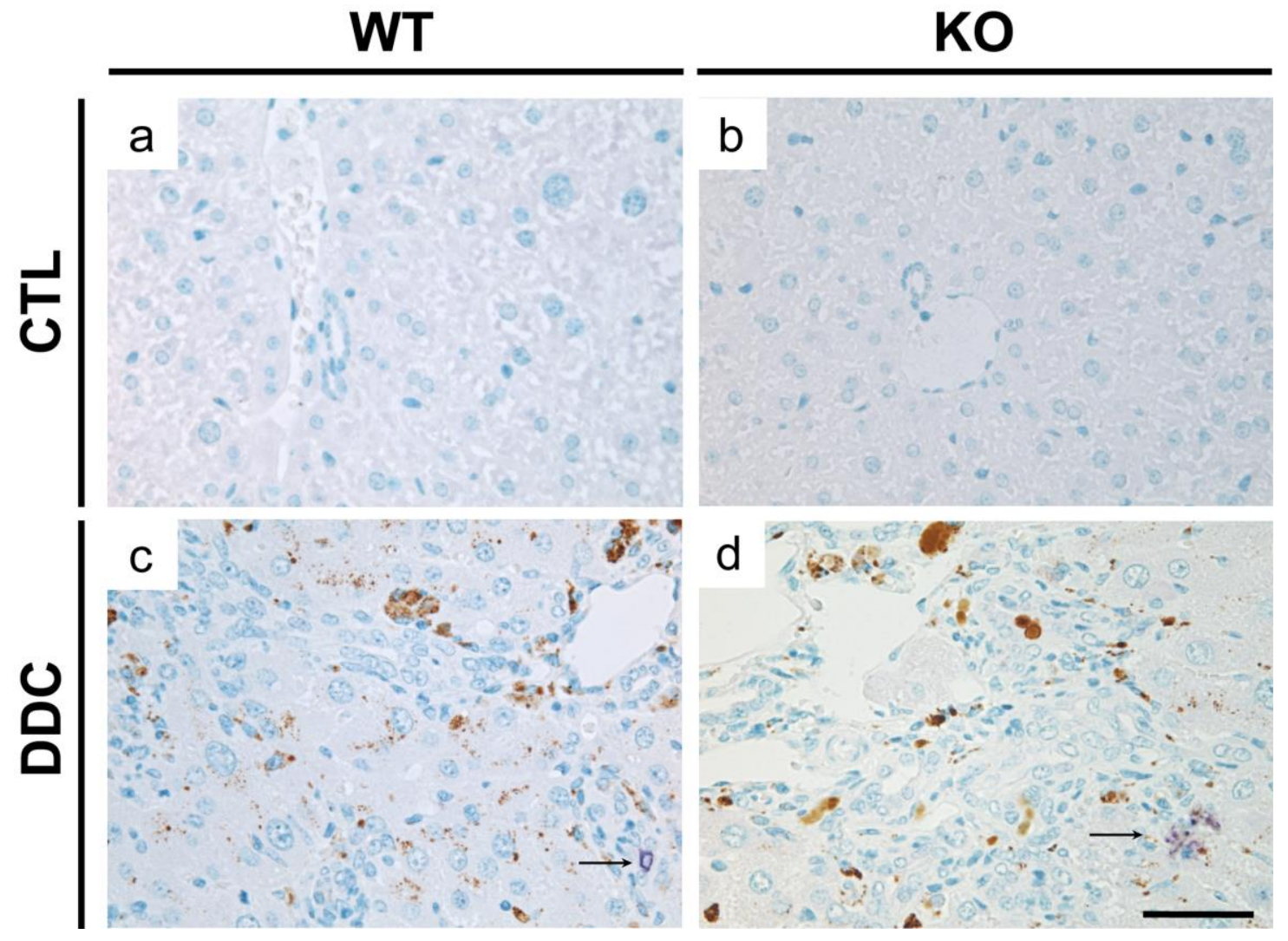

Figure 17. Immunohistochemistry (IHC) staining of D237 epitope in control (CTL) and 4w-DDC-fed (DDC) livers. Immunostaining for the apoptotic marker D237 (in purple color) shows that DDC-feeding leads to a moderate increase in apoptosis of biliary epithelial cells (BECs) compared to the situation seen in control (CTL) animals. No obvious differences between Keratin 19- wildtype (WT) and -knockout (-KO) animals were noted. Scale bar $=50 \mu \mathrm{m}$.

\subsubsection{DDC-induced oval cell activation is attenuated in K19-KOs}

It has been shown previously that DDC feeding results in oval cell activation which is at least in part negatively regulated by transforming growth factor (TGF) beta1 [123]. Given that we found significantly elevated TGF beta1 mRNA levels in DDC-fed K19-KOs. We performed IF staining for A6, an established oval cell marker, together with panK staining to assess the rate of oval cells within panK- positive population. Morphometric quantification revealed that the amount of oval cells dramatically increased after 4-week DDC feeding, however, a lower percentage of A6-positive cells was detected in DDC-fed K19-KOs compared to WTs (Figure 18 and Table 24). 


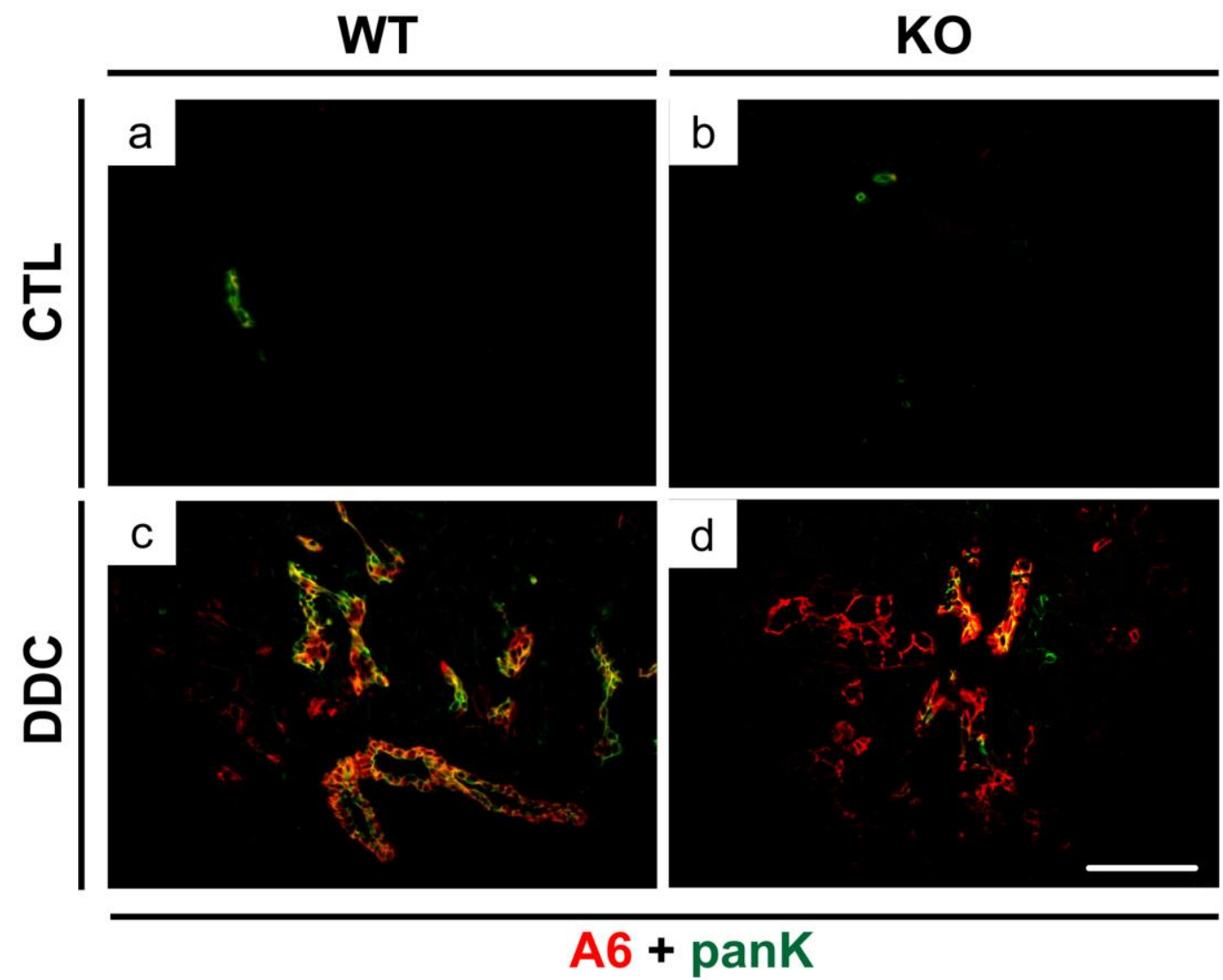

Figure 18. Double immunofluorescence (IF) staining for pankeartin (panK) and A6 in control (CTL) and 4w-DDC-fed (DDC) livers. A6-positive oval cells are visualized in red while panK-positive biliary epithelia are shown in green. Note a significantly lower amount of A6-positive oval cells within panKpositive biliary epithelium of DDC-fed Keratin 19 knockouts (KOs) when compared to equally challenged wildtypes (WTs). Scale bar $=100 \mu \mathrm{m}$.

\subsubsection{DDC-induced Notch2 signaling is impaired in K19-KOs}

As Notch signalling is known to regulate cholangiocyte differentiation and is modified by intermediate filaments including K19 [52, 108, 165], we tested whether notch2 signaling was altered in DDC-fed K19 KOs. Double IF staining for panK and Notch2 was applied and the percentage of Notch2-postive cholangiocytes per IHBD was calculated. The percentage of notch2-positive signals within panK-positive cells was significantly decreased in DDC-fed K19-KOs compared to WTs $(49 \% \pm 7,3 \%$ vs. $29 \% \pm 1,8 \%$, p < 0,05, Figure 19 and Table 24), suggesting that deletion of K19 leads to an impaired Notch2 signaling in DDC-fed animals. 


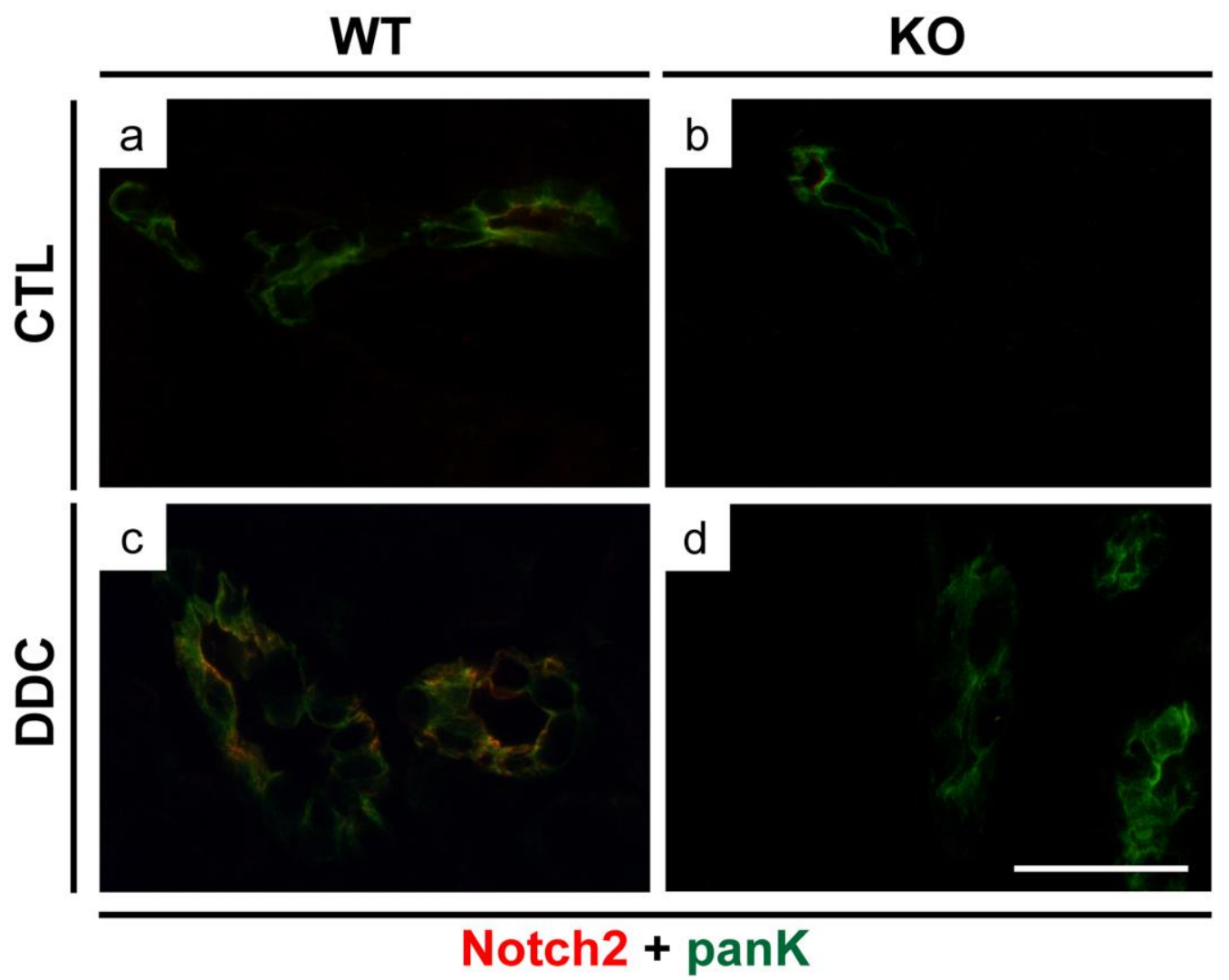

Figure 19. Double immunofluorescence (IF) staining for pankeatin (panK) and Notch2 in control (CTL) and 4w-DDC-fed (DDC) livers. IF signals for Notch2 (red) and panK (green) illustrate an increased percentage of Notch2-positive biliary epithelial cells (BECs) in DDC-fed wildtypes (WTs) while less double positive cells are found in DDC-fed Keratin 19 knockouts (KOs). Scale bar $=25 \mu \mathrm{m}$.

Taken together, these data illustrate that K19 is needed for anefficient Notch2- mediated oval cell-driven biliary regeneration and these findings explain the lower extent of ADP seen in DDC-fed K19-KOs.

\subsubsection{K19 deletion attenuates DDC-induced biliary fibrosis}

Next, we evaluated the DDC-mediated biliary fibrosis. 4 week DDC treatment leads to a dramatic scar formation around portal areas as demonstrated in Sirius red stained liver sections (Figure 20). However, a significantly lower level of biliary fibrosis was observed in DDC-fed K19-KOs as determined by evaluation of both H\&E and Sirius red stained liver slides (Figure 20 and Table 22). 


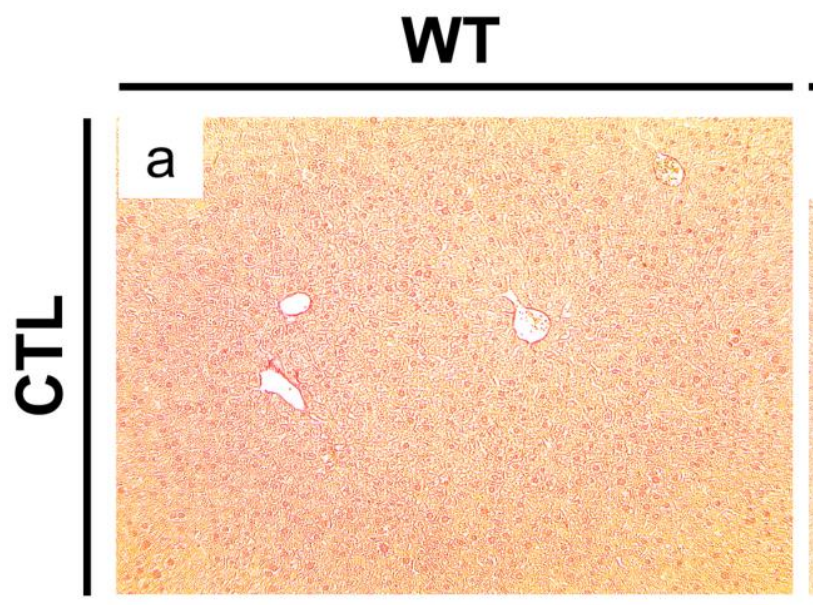

KO
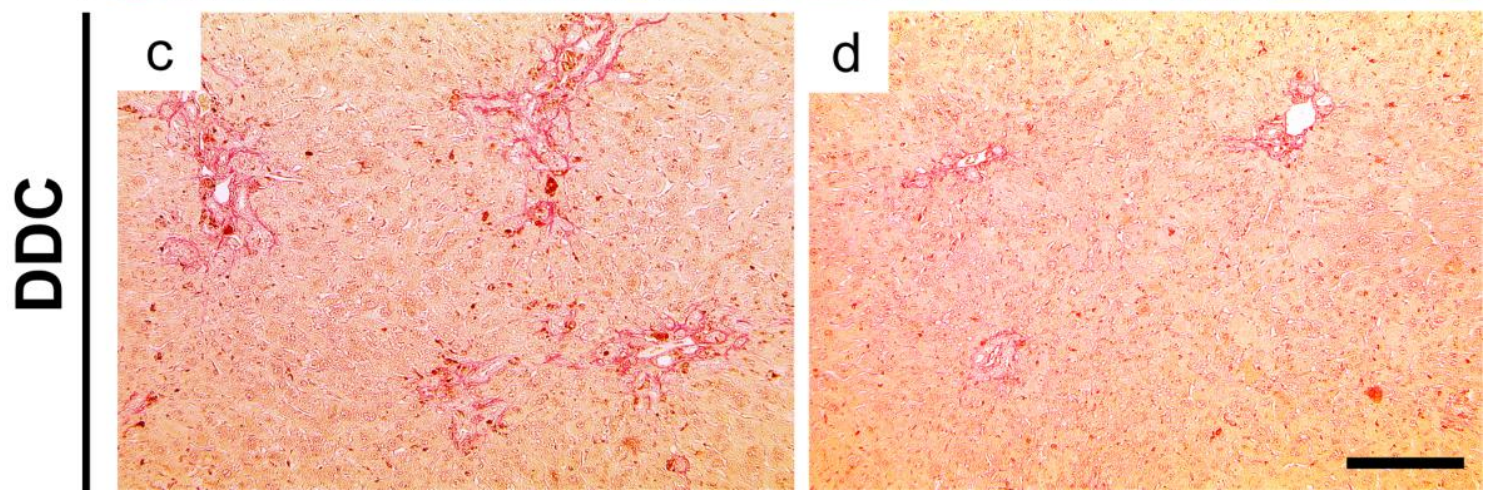

Figure 20. Sirius red staining of control (CTL) and 4w-DDC-fed (DDC) livers. The development of DDC-induced biliary fibrosis is attenuated in Keratin 19 knockouts (K19-KOs) compared to wildtypes (WTs). Scale bar $=200 \mu \mathrm{m}$.

These data were further supported by quantitative real time RT-PCR for fibrosis marker alpha-1 type I collagen (Col1a1), and hepatic hydroxyproline assay, respectively. To that end, lower col1a1 mRNA expression (Figure 21) and hepatic hydroxyproline content (Figure 22) were observed in DDC-fed K19-KOs. Therefore, our results clearly demonstrate that K19 loss ameliorates the development of DDC-induced biliary fibrosis. 


\section{Col1a1 mRNA}

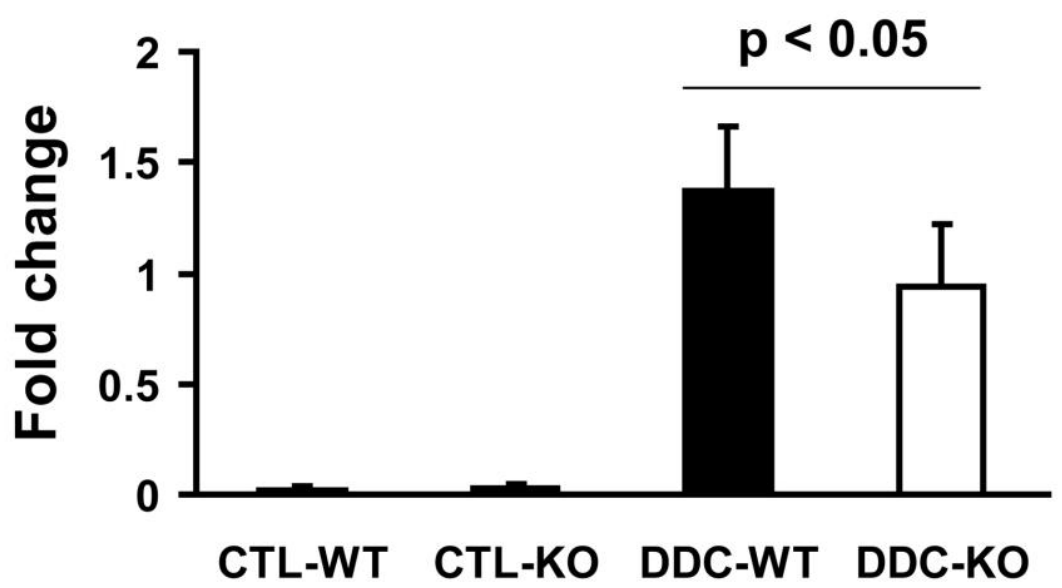

Figure 21. Quantitative real-time RT-PCR for alpha-1 type I collagen (Col1a1) gene in control (CTL) and 4w-DDC-fed (DDC) livers. Real-time RT-PCR analysis reveals elevated hepatic colla1 mRNA level in DDC-fed versus control animals. Note that DDC-fed Keratin 19 knockouts (KOs) display significantly lower collagen mRNA levels than WTs.

Hydroxyproline assay

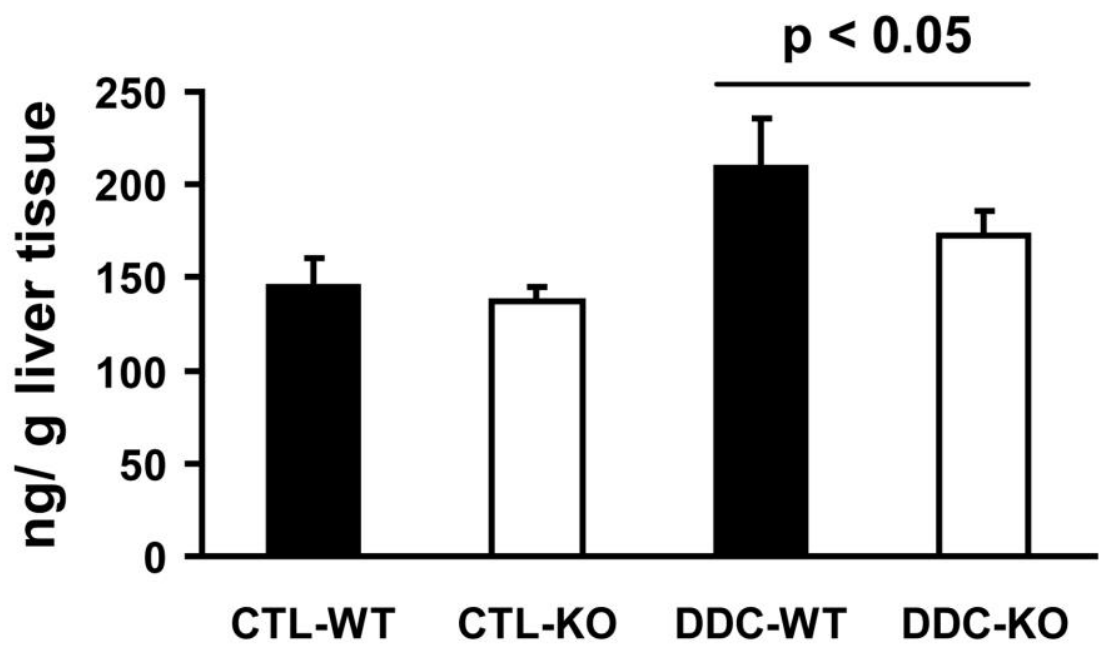

Figure 22. Hepatic hydroxyproline assay. Increased hydroxyproline levels are detected in DDC-fed animals compared to untreated controls (CTL). On the other hand, a significantly lower hydroxyproline amount is found in DDC-fed Keratin 19 knockouts (19-KOs) versus wildtypes (WTs). 


\subsection{Loss of K19 does not affect bile duct obstruction- related injury}

Since DDC-treated K19-KO mice displayed higher serum bile acid levels as well as stronger cholestatic injury due to obstruction of IHBDs, we wondered whether K19 may influence bile duct obstruction- related liver injury. To test the latter, CBDL was performed in K19-KOs and WTs and the extent of hepatic/ biliary injury was checked 5 days or 21 days after operation [127].

CBDL resulted in severe ductular reaction and fibrotic injury (Figure 23 and 24), however, neither serum liver damage markers (Figure 25 and 26) nor Colla1 mRNA level (not shown) showed significant difference between the ligated K19-KO and WT livers, indicating that deletion of K19 didn't modulate this type of liver injury. 


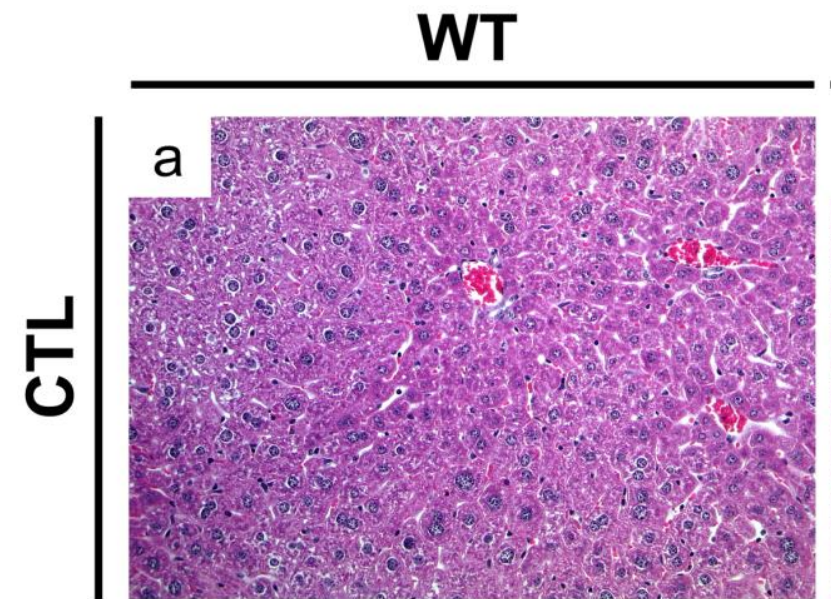

KO
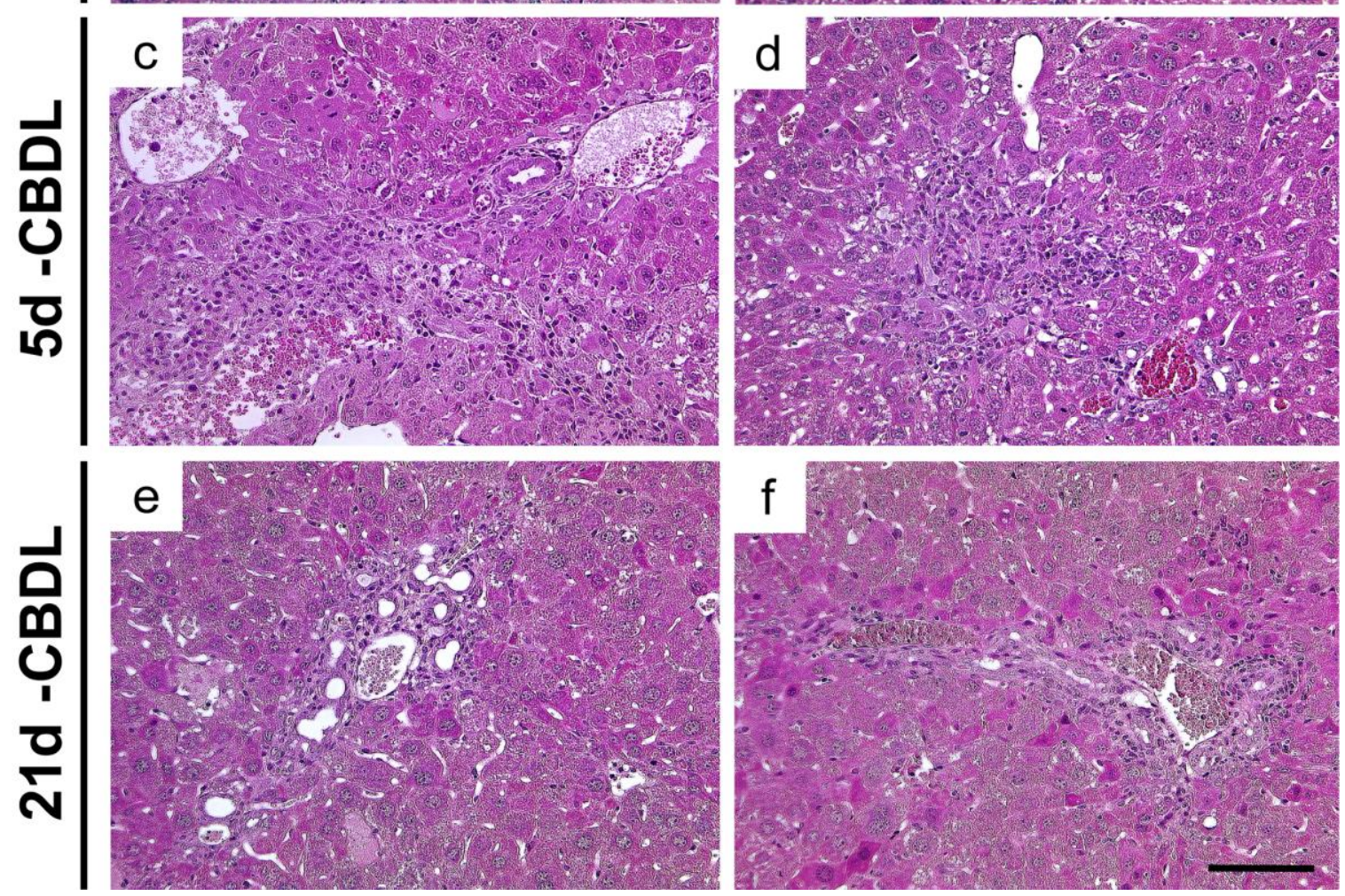

Figure 23 Hematoxylin and eosin (H\&E) staining from control (CTL) and common bile duct ligated (CBDL) livers. Liver histology from CTL, 5 days past CBDL, and 21 days past CBDL demonstrates that loss of keratin (K) 19 didn't modify the extent of CBDL-induced liver injury in that both K19 knockout (KO) and wildtype (WT) animals show a similar extent of ductular reaction and necrosis. Scale bar $=100 \mu \mathrm{m}$. 


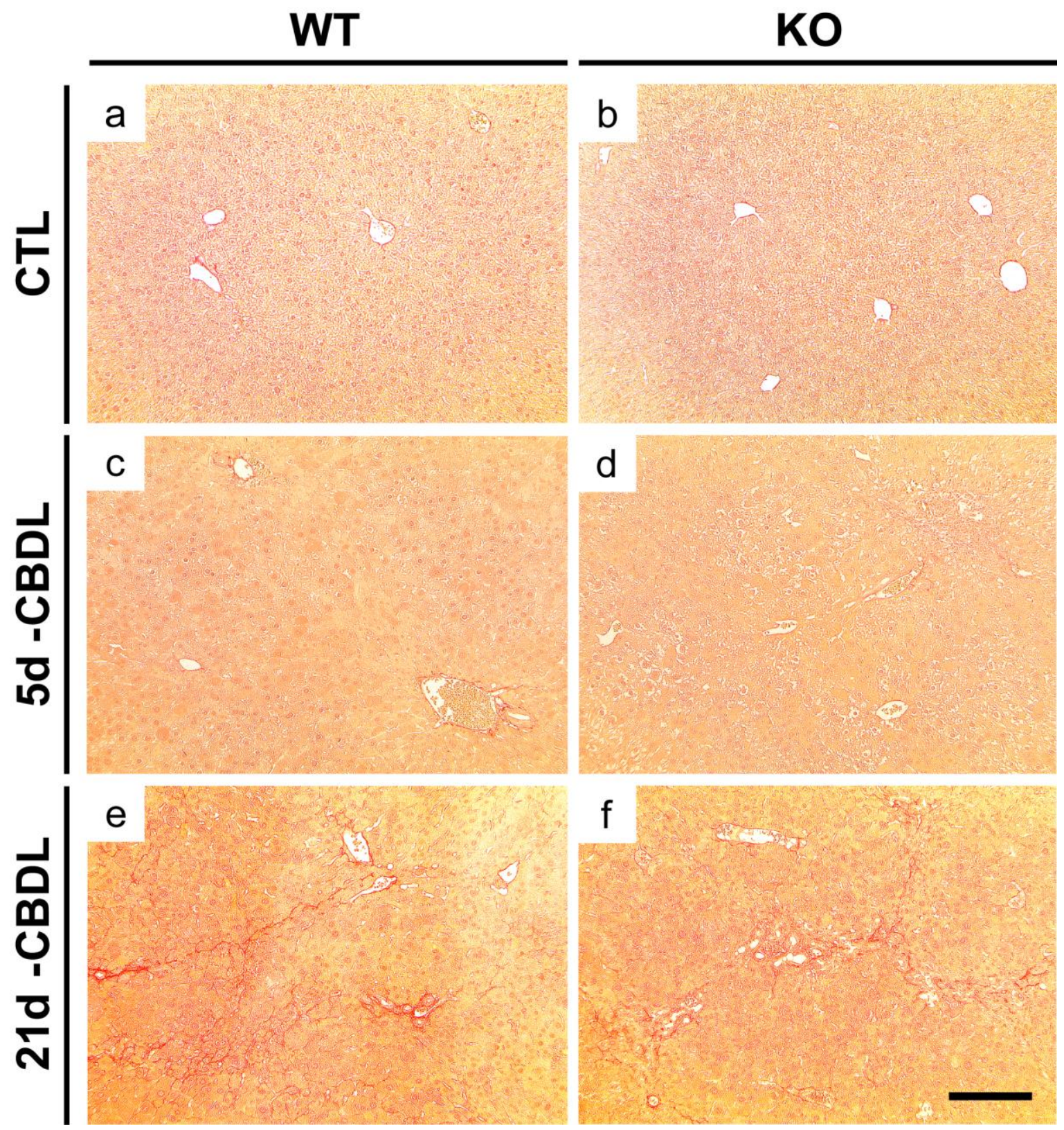

Figure 24. Sirius red staining of control (CTL) and common bile duct ligated (CBDL) livers. CBDLinduced fibrosis develops gradually after the operation, but the extent of fibrosis didn't differ between Keratin 19 knockouts (K19-KOs) and wildtypes (WTs). Scale bar $=200 \mu \mathrm{m}$. 


\section{Serum biochemistry}

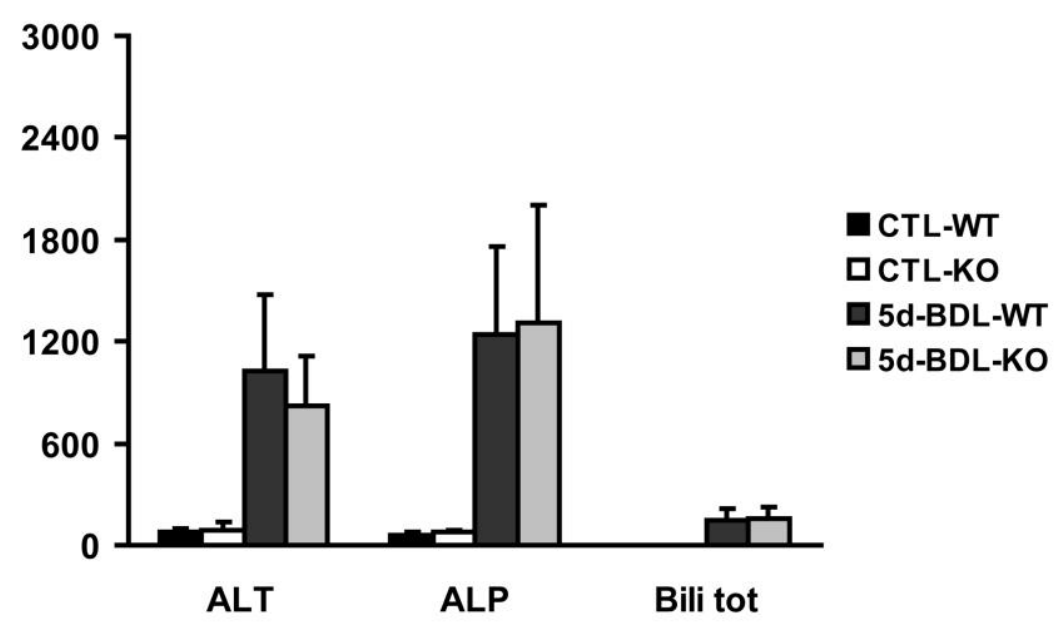

Figure 25. Serum biochemical analysis of control (CTL) mice and animals 5 days after common bile duct ligation (5d-BDL). CBDL induces a severe liver injury as evidenced by dramatically elevated alanine transaminase (ALT), alkaline phosphatase (ALP), and total bilirubin (Bili tot) levels. However, Keratin 19 knockout (KO) didn't affect any of these serological markers.

\section{Serum biochemistry}

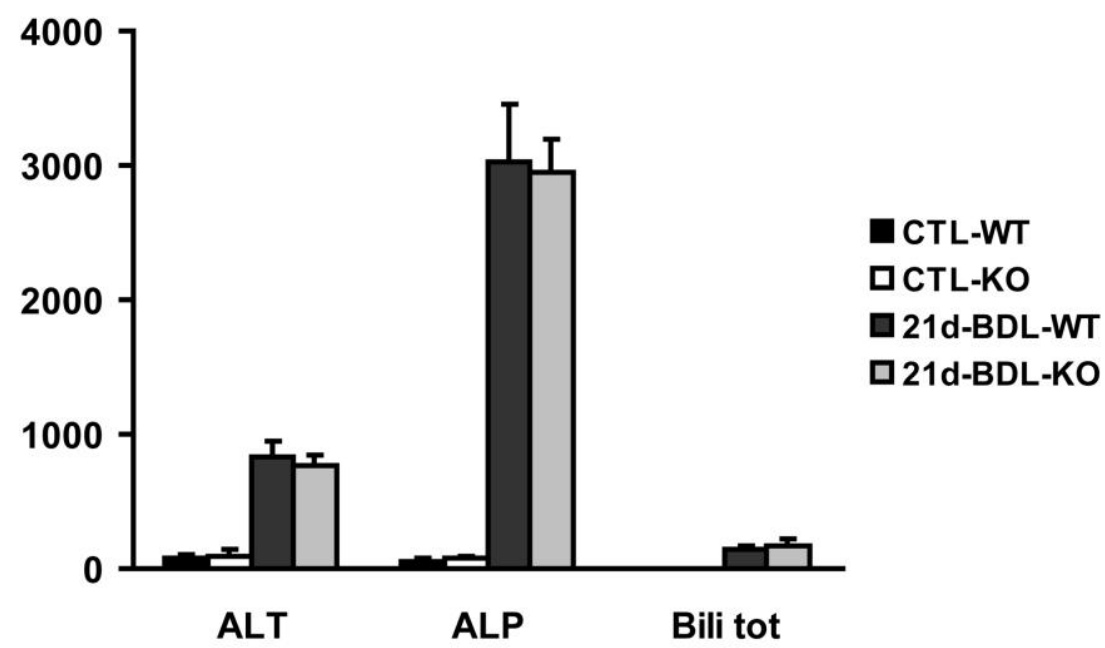

Figure 26. Serum biochemical analysis of control (CTL) animals and mice 21 days after common bile duct ligation (21d-BDL). Although CBDL-induced cholestatic injury is clearly present 21 days after BDL as evidenced by elevated alkaline phosphatase (ALP) and total bilirubin (Bili tot) levels, no difference was observed between Keratin 19 knockouts (K19-KOs) and wildtypes (WTs). ALT, alanine transaminase. 
To sum up, loss of K19 leads to a stronger cholestatic injury after chronic DDC feeding due to an impaired ADP (Figure 27). On the other hand, loss of K19 does not affect bile acid secretion or the extent of bile duct obstruction associated liver injury. The lower ADP presumably contributes to the lower extent of biliary fibrosis observed in DDC-fed K19KOs.

A

\section{Control}
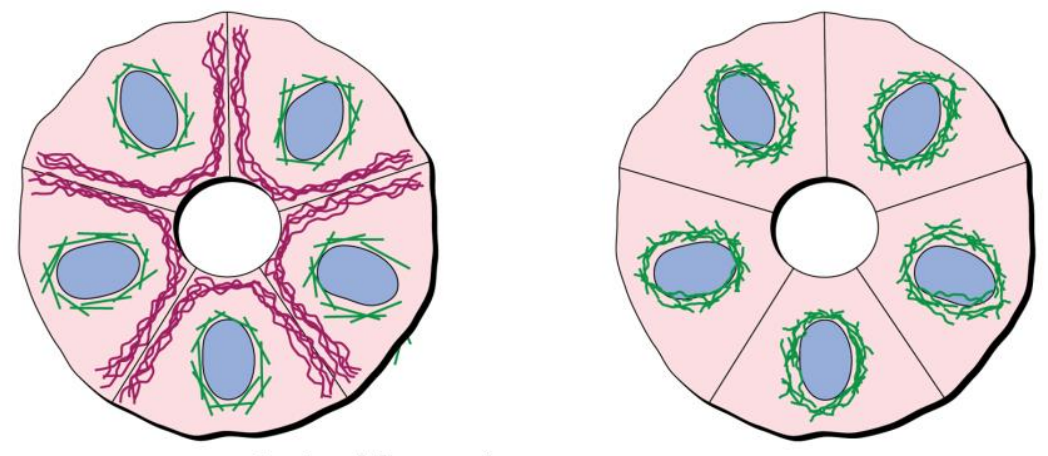

Apical keratins Cytoplasmic keratins

B

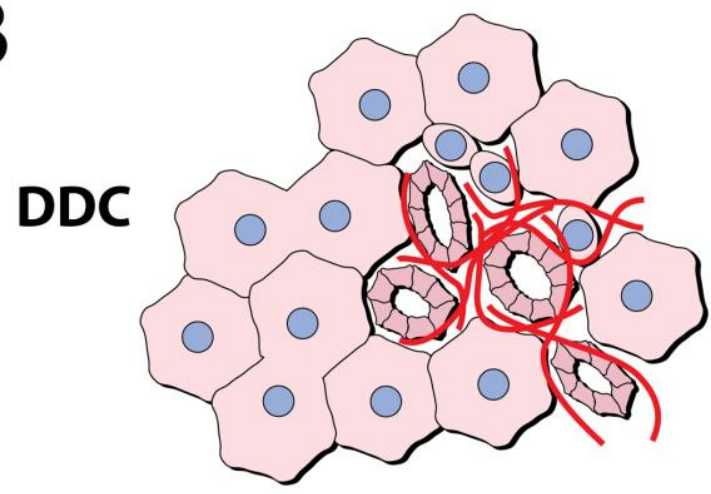

$\downarrow$ Ductular reaction

$\downarrow$ Biliary fibrosis

$\downarrow$ Oval cell activation

$\downarrow$ Notch2 signaling

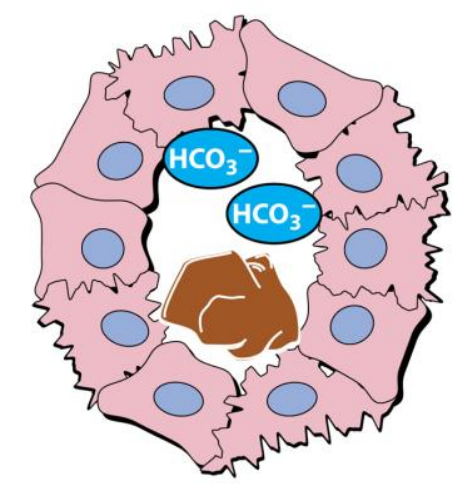

$\uparrow$ Biliary obstruction

$\uparrow$ Biliary injury

$\downarrow \mathrm{HCO}_{3}{ }^{-}$output

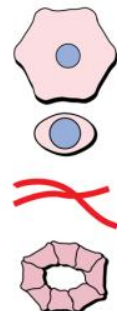

Hepatocyte

0

Normal cholangiocyte

Oval cell

Biliary fibrosis

Bile duct

Damaged Cholangiocyte

Porphyrin stone 
Figure 27. Schematic figure of pathological differences between keratin 19 wildtype (K19-WT) and knockout (K19-KO) mice. (A) Under basal condition, K19-KO mice undergo a re-distribution of biliary keratins towards a more cytoplasmic staining, but exhibit otherwise largely normal biliary epithelium. (B) After 4-week DDC treatment, K19-KO mice display a more severe biliary injury and biliary obstruction which may be due to a loss of the protective bicarbonate secretion and also a weaker atypical ductular reaction (ADP). Concomitantly, DDC-fed K19-KOs show impaired Notch2 signaling in biliary epithelium and a lower extent of oval cell activation. Of note, the weaker ADP in DDC-fed K19-KOs correlates with attenuated biliary fibrosis. 


\section{Discussion}

\subsection{Loss of K19 is well-compensated under physiological conditions}

Given the established cytoprotective role of keratins in the maintenance of cellular homeostasis and the fact that K19 is expressed primarily in ductal-type epithelia [7, 13], I analyzed the importance of K19 in biliary system. Under basal condition, K19-KOs did not develop an obvious biliary pathology as suggested by normal bilirubin/ALP/serum bile acids and by unrevealing histological examination. This is not surprising since defects in simple epithelial keratins often result in no/minimal phenotype in unstressed animals but can lead to a marked stress predisposition [13]. For example, in K7-KO mice, no apparent biliary alterations were reported, however, it remains unclear, how detailed analysis of biliary system was performed in these animals [166]. Much more data are available on K8and K18-KO animals that displayed unaltered serum ALP and total bilirubin levels as well as normal relative bile duct area $[126,167]$. Of note, the lack of apparent biliary phenotype in $\mathrm{K} 8$-KOs is rather surprising, since they have obvious changes in other tissues. These include mild chronic hepatitis and partially distorted hepatic and pancreatic morphological structure [168] as well the development of spontaneous colitis that is likely because of disrupted epithelial polarity and by the mistargeting of transporters [27-28].

I also examined the impact of K19 loss on other biliary keratins and found no changes in expression of $\mathrm{K} 7 / \mathrm{K} 8$ and $\mathrm{K} 18$. This is somewhat surprising since it has been reported previously that K19 deficiency results in upregulation of K18 and K20 in the gallbladder [169]. Even bigger changes were found in gallbladders of K8-KO animals that were largely devoid of any keratins [169]. On the other hand, no/minimal alterations were seen in gallbladders of K18-KOs which is well in line with the fact that K18 is less abundant in the mouse gallbladder than K19 [169]. Unfortunately, the effect of keratin deficiencies on keratin expression in the common bile duct has not been systematically analyzed yet and further studies should focus on this important topic.

While loss of K19 did not result in altered expression of biliary keratins, it led to a redistribution of the biliary keratin network from a predominantly apical to a non-polarized cytoplasmic pattern. This is reminiscent on what has been observed in pancreatic acinar cells: In these cells, K19 is found only in apicolateral (AL) keratin filaments while 
cytoplasmic (C) filaments consist only of K8/K18 [170]. Of note, the loss of K18 does not affect the AL keratin compartment, but the consequences of K19 deficiency have not been systematically analyzed [170]. Last but not least, although the impact of K19 on the polarity of keratin network in other tissues was not studied, accumulating evidence suggests that keratins can modulate not only the polarity of their own network, but the polarity of the whole cell [27, 38, 171-172].

Lastly, I also found that the bile flow and bile composition under basal condition was not affected by the loss of K19. Similarly, K8- and K18-KOs displayed an unaltered bile flow and normal levels of major bile components [126]. The normal excretory function of K19KO cholangiocytes is also supported by the fact that we did not see obvious differences in the amount of cholangiocyte-specific transporters such as aquaporin 1 (AQP1), anion exchange protein 2 (AE2) and cystic fibrosis transmembrane conductance regulator (CFTR; unpublished data; [173]). While loss of either K8 or K18 didn't result in mistargeting of hepatobiliary transporter proteins under basal conditions [126], the localization of these proteins in K19-deficient animals remains to be thoroughly analyzed.

\subsection{Loss of K19 results in a susceptibility to DDC-induced cholestatic liver injury}

\subsubsection{K19-KO mice suffer a more severe DDC-induced biliary injury}

After 4-week DDC feeding, I found significantly elevated serum ALP, total bilirubin, and bile acid levels in DDC-fed K19-KO mice compared to DDC-fed WTs. ALP is expressed in a number of tissues including liver, bone, and placenta [174] and consequently increased serum ALP levels are found in various pathological situations such as cholestasis and Paget's disease, since both damaged cholangiocytes and increased osteoblast activities result in higher release of ALP into blood [175]. On the other hand, no difference in ALP expression was found between the genotypes, thereby excluding the possibility that the observed effect is due to stronger production. Bilirubin is the metabolic product of heme, which is taken up by hepatocytes and secreted into the bile [176]. Increased serum total bilirubin level can be caused by a wide range of diseases including increased bilirubin production (e.g. due to hemolysis), decreased bilirubin excretion (e.g. due to hepatitis and cholestasis) and disrupted bilirubin metabolism (e.g. hereditary and neonatal jaundice) [177-178]. Elevated serum bile acid levels can be detected in patients with acute or chronic liver diseases because of the disrupted hepatic uptake [179], intrahepatic shunting or 
reduced hepatic excretion [180]. Collectively, the combination of the above clinical findings suggests that loss of K19 leads to a more severe DDC-induced cholestatic liver injury. In contrast, loss of either K8 or K18 had no effect on the DDC-induced cholestasis since comparable levels of serum ALP and total bilirubin were measured both 1 week and 12 weeks after DDC feeding [167]. On the other hand, the peak of DDC-induced biliary injury occurs 4 weeks after the start of feeding, and this time point might therefore be more useful to evaluate the role of K8/K18 in DDC-induced biliary injury. As a potential mechanism for the stronger cholestatic injury, loss of K19 may result in inherent biliary cell fragility. In this respect, previous studies showed hepatocyte fragility in K8-KO, K18KO and K18 mutant mice. Of note, such defects may not be apparent under basal condition, but become critical under stress situations as it has been described in various keratin mutation-based skin disorders [13, 181].

Furthermore, an analysis of bile composition revealed lower bicarbonate concentrations in DDC-fed K19-KOs compared to DDC-fed WTs. This finding might contribute to the higher cholestatic injury given the importance of biliary bicarbonate umbrella to prevent cholangiocytes from toxicity of hydrophobic bile acids [76]. However, further studies are needed to uncover mechanisms responsible for the lower biliary bicarbonate content in DDC-fed K19-KOs. In this respect, the expression of the cholangiocyte specific transporter AE2 that is responsible for the biliary bicarbonate secretion [182], did not differ between DDC-fed K19-KO and -WT livers. Further studies should analyze the possibility that loss of K19 leads to mistargeting of cholangiocyte transporters in context of chronic cholestatic injury.

Although more severe biliary injury was observed in DDC-fed K19-KO livers, loss of K19 didn't affect the extent of biliary apoptosis. On the other hand, previous studies showed that K8-KO, K8- and K18- mutant mice are more sensitive to Fas-mediated apoptosis [29, 40, 183]. However, importance of keratins in apoptosis may be condition- and tissuedependent, given that $\mathrm{K} 8$ deficiency renders colonocyte resistant to apoptosis in a microflora-dependent manner [184], and decreased hepatic apoptosis was observed in K8and K18-KO mice after DDC feeding [167]. Similarly, K18 R90C mutation predisposes to Fas-, but not to hyperglycosylation-induced injury $[183,185]$. 
As a potential reason for the increased cholestatic injury in DDC-fed K19-KOs, I found that these animals have more bile ducts blocked by porphyrin pigments. This does not seem to be due to differences in porphyrin accumulation given that similar levels were found in both groups. The latter observation is not surprising since K8-loss also did not result in porphyrin retention [167]. A reduced bile flow might be responsible for the increased stone formation, given that DDC feeding leads to reduced bile flow in both K8and K18-KO mice compared to DDC-fed WTs [126]. In that respect, the downregulated sstr2 gene expression in DDC-fed KOs may function as compensatory effect against such a decreased bile flow. Therefore, future studies should analyse the impact of K19 on bile flow under stress conditions. Another factor that is known to affect the stone formation in general is the biliary $\mathrm{pH}$ [186-187]. Although the importance of biliary $\mathrm{pH}$ in porphyrin stone formation is poorly understood, previous studies revealed that increased biliary $\mathrm{pH}$ induced the hydrolysis of conjugated bilirubin to insoluble indirect bilirubin and precipitated the aggregate formation [186-187]. However, this clinical finding does not seem to explain our observation given that DDC-fed K19-KOs showed decreased biliary bicarbonate concentration and therefore will most likely have a decreased biliary $\mathrm{pH}$. Besides, ionized calcium is also an important contributor to bile stone formation [188]. Future studies are needed to evaluate if loss of K19 has any effect on biliary calcium concentration.

\subsubsection{Decreased DDC-induced ductular reaction and LPC proliferation in K19-KO livers is due to impaired Notch2 signaling}

I found that loss of K19 led to less DDC-induced ductular reaction, which is because of decreased proliferation of biliary cells. This finding is consistent with previous studies demonstrating the importance of keratins in cell proliferation. In that respect, deletion of K17 delayed tumor growth and epithelial proliferation [189], and stratified epithelial cells with a knockdown of K14 exhibited reduced proliferation and tumor progression as well [190]. On the other hand, elevated ductular reaction was seen in K8- and K18-KO livers compared to WTs after 12-week DDC feeding [167]. Therefore, future studies are needed to delineate the contribution of different biliary keratins to ductular reaction. 
Next, since chronic DDC feeding induces activation of LPC [123], I evaluated the amount of activated LPC and found less LPCs in DDC-fed K19-KOs, indicating that K19 plays an essential role in DDC-induced LPC proliferation during biliary regeneration. This is consistent with a recent study showing that K19 expression in HCC was associated with increased tumor size and bad prognosis $[52,54,191]$. Furthermore, our finding might be relevant to the pathogenesis of biliary diseases such as PBC since K19 variants, K19 G17S, was identified in patients with advanced PBC [57].With regard to our findings, it is tempting to speculate that diminished regenerative ability in K19 deficient ductal cells may contribute to the development of ductopenia that is seen in advanced PBC. To support this hypothesis, OV-6 positive ductular structures were observed in patients with $\mathrm{PBC}$, thereby demonstrating that LPC proliferation really takes place in these subjects [192].

I also found less Notch2 positive cholangiocytes in DDC fed K19-KO bile ducts suggesting that loss of K19 leads to impaired Notch2 signaling. Since previous study showed that IL-6 directly stimulates the activation of LPCs in vitro [193], I checked IL-6 expression levels after chronic DDC feeding but comparable amounts were found in both genotypes (unpublished data). Of note, our finding that inhibited DDC-induced LPC activation in K19-KOs is due to impaired Notch2 signaling is consistent with previous studies demonstrating that intermediate filaments affect the Notch signaling. For example, astrocytes lacking both GFAP and vimentin exhibited decreased Notch signaling [165]; Nuclear IF lamin A seems to also stimulate Notch signaling given that mutation in lamin A compromises the ability to activate downstream targets of Notch [194].

\subsubsection{Ameliorated DDC-induced biliary fibrosis in K19-KO livers may be due to inhibited LPC proliferation}

I found less DDC-induced biliary fibrosis in K19-KO livers. This finding is somewhat unexpected given that clinical observations often show a close correlation between the severity of cholestatic disease and the rate of fibrosis development as it has been reported for PBC patients [195]. On the other hand, the decreased liver scarring in K19-KOs might be due to less pronounced ductular reaction seen in these animals. To that end, a previous study demonstrated that the extent of choline-deficient, ethionine-supplemented (CDE)diet induced liver fibrosis was decreased in BALB/c mice that display an attenuated LPC 
activation [196]. However, an inhibition of tumor necrosis factor-like weak inducer of apoptosis (TWEAK), that represents a regulator of the mitogenic LPC response [197-198], ameliorated $\mathrm{CCl}_{4}$ induced fibrogenic response [199].

\subsection{Loss of K19 does not affect the development of cholestatic liver injury induced by CBDL}

After CBDL, I found comparable levels of liver injury, hepatic necrosis, ductal proliferation and hepatic inflammation, suggesting that loss of K19 had no significant effect on CBDL-induced liver damage. This observation clearly differs from the findings in DDC-treated animals and suggests that the importance of K19 might be restricted to specific cholestatic disorders. In that respect, primary large cholangiocytes are affected and respond to CBDL-induced damage [65], whereas there seem to be no significant participation of LPCs in the biliary proliferation as suggested by radioactive labeling studies [145]. Therefore, it is tempting to hypothesize that K19 might be important primary in small ducts and LPCs that are targeted by DDC-hepatotoxicity but might be dispensable in large cholangiocytes that are injured during CBDL. In that respect, several studies demonstrated a morphological and functional heterogeneity of biliary epithelia [64].

Similarly, loss of K19 also had no effect on CBDL-induced fibrosis. This again meshes well with previous human and experimental observations showing that Ks are important for liver fibrosis progression only in specific situations. For example, in mice, a dominant negative mutation in K18 accelerated thiacetamide (TAA)-induced liver fibrosis but had no impact on $\mathrm{CCl}_{4}$-induced liver scaring [149]. In humans, presence of $\mathrm{K} 8 / \mathrm{K} 18$ variants has been shown to predispose to development of advanced liver fibrosis in patients with chronic hepatitis $\mathrm{C}$ and to development of advanced disease in PBC [57, 200], whereas the same exonic K8/K18 variants did not influence the fibrogenic process in patients with hemochromatosis [201]. Another report supporting our data comes from Scholten et al., who performed lineage tracing and did not find any transdifferentiation of K19 positive cholangiocytes into extracellular matrix producing cells [202].

In summary, my data suggest that K19 plays an important role in development of specific cholestatic injuries. Further studies will be needed to determine, to what extent it plays a 
role in human cholestatic disorders such as $\mathrm{PBC}$ as well as in development of hepatocellular or cholangiocellular carcinoma. 


\section{Summary}

Keratins (Ks) constitute the largest subfamily of intermediate filaments and are expressed in epithelial cells in a cell type-specific manner. K19 is found predominantly in ductal epithelia. In the liver, K19 is located in cholangiocytes and liver progenitor cells (LPCs) but not in mature hepatocytes and represents an established biliary/LPC marker. Animals lacking K19 display no obvious epithelial phenotype under basal conditions. On the other hand, K19 is expressed in a subset of invasive hepatocellular carcinomas with poor prognosis and K19 mutations were detected in patients with primary biliary cirrhosis (PBC). Given the established cytoprotective function of Ks, I studied the importance of K19 in cholangiocytes/LPCs.

Biliary $\mathrm{K}$ expression/localization as well as bile composition was analyzed in untreated K19 wildtype (WT) and knockout (KO) mice. The animals were also fed with $0.1 \%$ 3,5diethoxycarbonyl-1,4-dihydrocollidine (DDC) for 4 weeks as an established model of sclerosing cholangitis and LPC proliferation or were subjected to common bile duct ligation (CBDL), a model of extrahepatic obstructive cholestasis. Liver/biliary injury markers were studied and histological analysis was performed to determine the extent of tissue injury. Ductular reaction, bile composition, ductular proliferation with LPC content and the development of biliary fibrosis were also assessed.

Under basal condition, K19-KO mice displayed a re-distribution of biliary keratins in cholangiocytes towards a more cytoplasmic localization, but had normal biliary epithelia without an alteration in keratin gene expressions or biliary composition. After chronic DDC feeding, K19-KO mice exhibited (compared to WT animals): (1) a more severe biliary injury with elevated serum alkaline phosphatase (ALP), total bilirubin, and bile acids levels; (2) a decreased biliary bicarbonate concentration; (3) a more extensive biliary obstruction and decreased expression of somatostatin receptor 2 that regulates bile production; (4) a diminished ductular reaction and lower LPC proliferation, which was associated with less prominent biliary Notch2 content; (5) an attenuated biliary fibrosis. On 
the other hand, comparable levels of liver injury, hepatic necrosis, ductal proliferation and fibrosis were observed 5 and 21 days after CBDL.

My results suggest that K19 plays an important role in LPCs and in small, but not large cholangiocytes. These findings may be of relevance for the pathogenesis of PBC that affects small cholangiocytes and displays strong activation of Notch signaling. 


\section{References}

1 Herrmann H, Bar H, Kreplak L, Strelkov SV, Aebi U. Intermediate filaments: from cell architecture to nanomechanics. Nat Rev Mol Cell Biol 2007;8:562-73.

2 Herrmann H, Strelkov SV, Burkhard P, Aebi U. Intermediate filaments: primary determinants of cell architecture and plasticity. J Clin Invest 2009;119:1772-83.

3 Eriksson JE, Dechat T, Grin B, Helfand B, Mendez M, Pallari HM, Goldman RD. Introducing intermediate filaments: from discovery to disease. $\mathrm{J}$ Clin Invest 2009;119:1763-71.

4 Coulombe PA, Wong P. Cytoplasmic intermediate filaments revealed as dynamic and multipurpose scaffolds. Nat Cell Biol 2004;6:699-706.

5 Chang L, Goldman RD. Intermediate filaments mediate cytoskeletal crosstalk. Nat Rev Mol Cell Biol 2004;5:601-13.

6 Strnad P, Paschke S, Jang KH, Ku NO. Keratins: markers and modulators of liver disease. Curr Opin Gastroenterol 2012;28:209-16.

7 Pan X, Hobbs RP, Coulombe PA. The expanding significance of keratin intermediate filaments in normal and diseased epithelia. Curr Opin Cell Biol 2013;25:4756.

8 Steinert PM, Jones JC, Goldman RD. Intermediate filaments. J Cell Biol 1984;99:22s-7s.

9 Coulombe PA, Tong X, Mazzalupo S, Wang Z, Wong P. Great promises yet to be fulfilled: defining keratin intermediate filament function in vivo. Eur $\mathrm{J}$ Cell Biol 2004;83:735-46.

10 Moll R, Franke WW, Schiller DL, Geiger B, Krepler R. The catalog of human cytokeratins: patterns of expression in normal epithelia, tumors and cultured cells. Cell 1982;31:11-24.

11 Bowden PE, Quinlan RA, Breitkreutz D, Fusenig NE. Proteolytic modification of acidic and basic keratins during terminal differentiation of mouse and human epidermis. Eur J Biochem 1984;142:29-36.

12 Schweizer J, Bowden PE, Coulombe PA, Langbein L, Lane EB, Magin TM, Maltais L, et al. New consensus nomenclature for mammalian keratins. J Cell Biol 2006;174:169-74. 
13 Omary MB, Ku NO, Strnad P, Hanada S. Toward unraveling the complexity of simple epithelial keratins in human disease. J Clin Invest 2009;119:1794-805.

14 Chu PG, Weiss LM. Keratin expression in human tissues and neoplasms. Histopathology 2002;40:403-39.

15 Haines RL, Lane EB. Keratins and disease at a glance. J Cell Sci 2012;125:3923-8.

16 Achtstaetter T, Hatzfeld M, Quinlan RA, Parmelee DC, Franke WW. Separation of cytokeratin polypeptides by gel electrophoretic and chromatographic techniques and their identification by immunoblotting. Methods Enzymol 1986;134:355-71.

$17 \mathrm{Ku}$ NO, Toivola DM, Zhou Q, Tao GZ, Zhong B, Omary MB. Studying simple epithelial keratins in cells and tissues. Methods Cell Biol 2004;78:489-517.

18 Steinert PM, Wantz ML, Idler WW. O-phosphoserine content of intermediate filament subunits. Biochemistry 1982;21:177-83.

19 Sun TT, Eichner R, Nelson WG, Tseng SC, Weiss RA, Jarvinen M, WoodcockMitchell J. Keratin classes: molecular markers for different types of epithelial differentiation. J Invest Dermatol 1983;81:109s-15s.

20 Omary MB, Coulombe PA, McLean WH. Intermediate filament proteins and their associated diseases. N Engl J Med 2004;351:2087-100.

21 Baribault H, Penner J, Iozzo RV, Wilson-Heiner M. Colorectal hyperplasia and inflammation in keratin 8-deficient FVB/N mice. Genes Dev 1994;8:2964-73.

$22 \mathrm{Ku}$ NO, Michie S, Oshima RG, Omary MB. Chronic hepatitis, hepatocyte fragility, and increased soluble phosphoglycokeratins in transgenic mice expressing a keratin 18 conserved arginine mutant. J Cell Biol 1995;131:1303-14.

$23 \mathrm{Ku} \mathrm{NO}$, Michie SA, Soetikno RM, Resurreccion EZ, Broome RL, Oshima RG, Omary MB. Susceptibility to hepatotoxicity in transgenic mice that express a dominantnegative human keratin 18 mutant. J Clin Invest 1996;98:1034-46.

24 Magin TM. Lessons from keratin transgenic and knockout mice. Subcell Biochem 1998;31:141-72.

$25 \mathrm{Ku}$ NO, Michie SA, Soetikno RM, Resurreccion EZ, Broome RL, Omary MB. Mutation of a major keratin phosphorylation site predisposes to hepatotoxic injury in transgenic mice. J Cell Biol 1998;143:2023-32.

26 Toivola DM, Ku NO, Ghori N, Lowe AW, Michie SA, Omary MB. Effects of keratin filament disruption on exocrine pancreas-stimulated secretion and susceptibility to injury. Exp Cell Res 2000;255:156-70. 
27 Toivola DM, Krishnan S, Binder HJ, Singh SK, Omary MB. Keratins modulate colonocyte electrolyte transport via protein mistargeting. J Cell Biol 2004;164:911-21.

28 Habtezion A, Toivola DM, Butcher EC, Omary MB. Keratin-8-deficient mice develop chronic spontaneous Th2 colitis amenable to antibiotic treatment. J Cell Sci 2005;118:1971-80.

$29 \mathrm{Ku} \mathrm{NO}$, Omary MB. A disease- and phosphorylation-related nonmechanical function for keratin 8. J Cell Biol 2006;174:115-25.

30 Vijayaraj P, Sohl G, Magin TM. Keratin transgenic and knockout mice: functional analysis and validation of disease-causing mutations. Methods Mol Biol 2007;360:203-51. 31 Arin MJ. The molecular basis of human keratin disorders. Hum Genet 2009;125:355-73.

32 McLean WH, Moore CB. Keratin disorders: from gene to therapy. Hum Mol Genet 2011;20:R189-97.

33 Coulombe PA, Omary MB. 'Hard' and 'soft' principles defining the structure, function and regulation of keratin intermediate filaments. Curr Opin Cell Biol 2002;14:110-22.

$34 \mathrm{Gu} \mathrm{LH}$, Coulombe PA. Keratin function in skin epithelia: a broadening palette with surprising shades. Curr Opin Cell Biol 2007;19:13-23.

35 Wagner OI, Rammensee S, Korde N, Wen Q, Leterrier JF, Janmey PA. Softness, strength and self-repair in intermediate filament networks. Exp Cell Res 2007;313:222835 .

36 Planko L, Bohse K, Hohfeld J, Betz RC, Hanneken S, Eigelshoven S, Kruse R, et al. Identification of a keratin-associated protein with a putative role in vesicle transport. Eur J Cell Biol 2007;86:827-39.

37 Kim S, Coulombe PA. Intermediate filament scaffolds fulfill mechanical, organizational, and signaling functions in the cytoplasm. Genes Dev 2007;21:1581-97.

38 Toivola DM, Tao GZ, Habtezion A, Liao J, Omary MB. Cellular integrity plus: organelle-related and protein-targeting functions of intermediate filaments. Trends Cell Biol 2005;15:608-17.

39 Kim S, Wong P, Coulombe PA. A keratin cytoskeletal protein regulates protein synthesis and epithelial cell growth. Nature 2006;441:362-5. 
40 Gilbert S, Loranger A, Daigle N, Marceau N. Simple epithelium keratins 8 and 18 provide resistance to Fas-mediated apoptosis. The protection occurs through a receptortargeting modulation. J Cell Biol 2001;154:763-73.

41 Oshima RG. Apoptosis and keratin intermediate filaments. Cell Death Differ 2002;9:486-92.

42 Bader BL, Magin TM, Hatzfeld M, Franke WW. Amino acid sequence and gene organization of cytokeratin no. 19, an exceptional tail-less intermediate filament protein. EMBO J 1986;5:1865-75.

43 Fradette J, Germain L, Seshaiah P, Coulombe PA. The type I keratin 19 possesses distinct and context-dependent assembly properties. J Biol Chem 1998;273:35176-84.

44 Washino S, Hirai M, Matsuzaki A, Kobayashi Y. Clinical usefulness of CEA, CA19-9, and CYFRA 21-1 as tumor markers for urothelial bladder carcinoma. Urol Int 2011;87:420-8.

45 Giovanella L, Treglia G, Verburg FA, Salvatori M, Ceriani L. Serum cytokeratin 19 fragments: a dedifferentiation marker in advanced thyroid cancer. Eur J Endocrinol 2012;167:793-7.

46 Roskams TA, Theise ND, Balabaud C, Bhagat G, Bhathal PS, Bioulac-Sage P, Brunt EM, et al. Nomenclature of the finer branches of the biliary tree: canals, ductules, and ductular reactions in human livers. Hepatology 2004;39:1739-45.

47 Larouche D, Lavoie A, Paquet C, Simard-Bisson C, Germain L. Identification of epithelial stem cells in vivo and in vitro using keratin 19 and BrdU. Methods Mol Biol 2010;585:383-400.

48 Iyer A, Robert ME, Bifulco CB, Salem RR, Jain D. Different cytokeratin and neuronal cell adhesion molecule staining patterns in focal nodular hyperplasia and hepatic adenoma and their significance. Hum Pathol 2008;39:1370-7.

49 Roskams T, Katoonizadeh A, Komuta M. Hepatic progenitor cells: an update. Clin Liver Dis 2010;14:705-18.

50 Tanaka M, Itoh T, Tanimizu N, Miyajima A. Liver stem/progenitor cells: their characteristics and regulatory mechanisms. J Biochem 2011;149:231-9.

51 Khan FM, Komarla AR, Mendoza PG, Bodenheimer HC, Jr., Theise ND. Keratin 19 demonstration of canal of Hering loss in primary biliary cirrhosis: "minimal change PBC"? Hepatology 2013;57:700-7. 
52 Govaere O, Komuta M, Berkers J, Spee B, Janssen C, de Luca F, Katoonizadeh A, et al. Keratin 19: a key role player in the invasion of human hepatocellular carcinomas. Gut 2014;63:674-85.

53 van Sprundel RG, van den Ingh TS, Desmet VJ, Katoonizadeh A, Penning LC, Rothuizen J, Roskams T, et al. Keratin 19 marks poor differentiation and a more aggressive behaviour in canine and human hepatocellular tumours. Comp Hepatol 2010;9:4.

54 Kim H, Choi GH, Na DC, Ahn EY, Kim GI, Lee JE, Cho JY, et al. Human hepatocellular carcinomas with "Stemness"-related marker expression: keratin 19 expression and a poor prognosis. Hepatology 2011;54:1707-17.

55 Tamai Y, Ishikawa T, Bosl MR, Mori M, Nozaki M, Baribault H, Oshima RG, et al. Cytokeratins 8 and 19 in the mouse placental development. J Cell Biol 2000;151:56372.

56 Stone MR, O'Neill A, Lovering RM, Strong J, Resneck WG, Reed PW, Toivola DM, et al. Absence of keratin 19 in mice causes skeletal myopathy with mitochondrial and sarcolemmal reorganization. J Cell Sci 2007;120:3999-4008.

57 Zhong B, Strnad P, Selmi C, Invernizzi P, Tao GZ, Caleffi A, Chen M, et al. Keratin variants are overrepresented in primary biliary cirrhosis and associate with disease severity. Hepatology 2009;50:546-54.

58 Alpini G, McGill JM, Larusso NF. The pathobiology of biliary epithelia. Hepatology 2002;35:1256-68.

59 Glaser SS, Gaudio E, Miller T, Alvaro D, Alpini G. Cholangiocyte proliferation and liver fibrosis. Expert Rev Mol Med 2009;11:e7.

60 Strazzabosco M, Fabris L. Functional anatomy of normal bile ducts. Anat Rec (Hoboken) 2008;291:653-60.

61 Turner R, Lozoya O, Wang Y, Cardinale V, Gaudio E, Alpini G, Mendel G, et al. Human hepatic stem cell and maturational liver lineage biology. Hepatology 2011;53:1035-45.

62 Benedetti A, Bassotti C, Rapino K, Marucci L, Jezequel AM. A morphometric study of the epithelium lining the rat intrahepatic biliary tree. J Hepatol 1996;24:335-42.

63 Tabibian JH, Masyuk AI, Masyuk TV, O'Hara SP, LaRusso NF. Physiology of cholangiocytes. Compr Physiol 2013;3:541-65. 

Evaluation of differential gene expression by microarray analysis in small and large cholangiocytes isolated from normal mice. Liver Int 2003;23:449-59.

65 Glaser SS, Gaudio E, Rao A, Pierce LM, Onori P, Franchitto A, Francis HL, et al. Morphological and functional heterogeneity of the mouse intrahepatic biliary epithelium. Lab Invest 2009;89:456-69.

66 LeSage GD, Glaser SS, Marucci L, Benedetti A, Phinizy JL, Rodgers R, Caligiuri A, et al. Acute carbon tetrachloride feeding induces damage of large but not small cholangiocytes from BDL rat liver. Am J Physiol 1999;276:G1289-301.

67 Alpini G, Glaser S, Robertson W, Rodgers RE, Phinizy JL, Lasater J, LeSage GD. Large but not small intrahepatic bile ducts are involved in secretin-regulated ductal bile secretion. Am J Physiol 1997;272:G1064-74.

68 Glaser S, Francis H, Demorrow S, Lesage G, Fava G, Marzioni M, Venter J, et al. Heterogeneity of the intrahepatic biliary epithelium. World J Gastroenterol 2006;12:352336.

69 Guzelian P, Boyer JL. Glucose reabsorption from bile. Evidence for a biliohepatic circulation. J Clin Invest 1974;53:526-35.

70 Ballatori N, Jacob R, Boyer JL. Intrabiliary glutathione hydrolysis. A source of glutamate in bile. J Biol Chem 1986;261:7860-5.

71 Benedetti A, Di Sario A, Marucci L, Svegliati-Baroni G, Schteingart CD, Ton-Nu HT, Hofmann AF. Carrier-mediated transport of conjugated bile acids across the basolateral membrane of biliary epithelial cells. Am J Physiol 1997;272:G1416-24.

72 Ballatori N, Truong AT. Glutathione as a primary osmotic driving force in hepatic bile formation. Am J Physiol 1992;263:G617-24.

73 Masyuk AI, Masyuk TV, Tietz PS, Splinter PL, LaRusso NF. Intrahepatic bile ducts transport water in response to absorbed glucose. Am J Physiol Cell Physiol 2002;283:C785-91.

74 Medina JF, Martinez A, Vazquez JJ, Prieto J. Decreased anion exchanger 2 immunoreactivity in the liver of patients with primary biliary cirrhosis. Hepatology 1997;25:12-7.

75 Melero S, Spirli C, Zsembery A, Medina JF, Joplin RE, Duner E, Zuin M, et al. Defective regulation of cholangiocyte $\mathrm{Cl}-\mathrm{HCO} 3(-)$ and $\mathrm{Na}+/ \mathrm{H}+$ exchanger activities in primary biliary cirrhosis. Hepatology 2002;35:1513-21. 
76 Beuers U, Hohenester S, de Buy Wenniger LJ, Kremer AE, Jansen PL, Elferink RP. The biliary $\mathrm{HCO}(3)(-)$ umbrella: a unifying hypothesis on pathogenetic and therapeutic aspects of fibrosing cholangiopathies. Hepatology 2010;52:1489-96.

77 Hirschfield GM, Heathcote EJ, Gershwin ME. Pathogenesis of cholestatic liver disease and therapeutic approaches. Gastroenterology 2010;139:1481-96.

78 Jungst C, Lammert F. Cholestatic liver disease. Dig Dis 2013;31:152-4.

79 Coleman R. Biochemistry of bile secretion. Biochem J 1987;244:249-61.

80 Esteller A. Physiology of bile secretion. World J Gastroenterol 2008;14:5641-9.

81 Reshetnyak VI. Physiological and molecular biochemical mechanisms of bile formation. World J Gastroenterol 2013;19:7341-60.

82 Forker EL. Two sites of bile formation as determined by mannitol and erythritol clearance in the guinea pig. J Clin Invest 1967;46:1189-95.

83 Nathanson $\mathrm{MH}$, Boyer JL. Mechanisms and regulation of bile secretion. Hepatology 1991;14:551-66.

84 Meier PJ, Stieger B. Bile salt transporters. Annu Rev Physiol 2002;64:635-61.

85 Trauner M, Boyer JL. Bile salt transporters: molecular characterization, function, and regulation. Physiol Rev 2003;83:633-71.

86 Bataller R, Brenner DA. Liver fibrosis. J Clin Invest 2005;115:209-18.

87 Farber E. Similarities in the sequence of early histological changes induced in the liver of the rat by ethionine, 2-acetylamino-fluorene, and 3'-methyl-4dimethylaminoazobenzene. Cancer Res 1956;16:142-8.

88 Shinozuka H, Lombardi B, Sell S, Iammarino RM. Early histological and functional alterations of ethionine liver carcinogenesis in rats fed a choline-deficient diet. Cancer Res 1978;38:1092-8.

89 Dabeva MD, Shafritz DA. Activation, proliferation, and differentiation of progenitor cells into hepatocytes in the D-galactosamine model of liver regeneration. Am J Pathol 1993;143:1606-20.

90 Wang X, Foster M, Al-Dhalimy M, Lagasse E, Finegold M, Grompe M. The origin and liver repopulating capacity of murine oval cells. Proc Natl Acad Sci U S A 2003;100 Suppl 1:11881-8.

91 Roskams TA, Libbrecht L, Desmet VJ. Progenitor cells in diseased human liver. Semin Liver Dis 2003;23:385-96. 
92 Duncan AW, Dorrell C, Grompe M. Stem cells and liver regeneration. Gastroenterology 2009;137:466-81.

93 Lowes KN, Brennan BA, Yeoh GC, Olynyk JK. Oval cell numbers in human chronic liver diseases are directly related to disease severity. Am J Pathol 1999;154:53741.

94 Libbrecht L, Desmet V, Van Damme B, Roskams T. Deep intralobular extension of human hepatic 'progenitor cells' correlates with parenchymal inflammation in chronic viral hepatitis: can 'progenitor cells' migrate? J Pathol 2000;192:373-8.

95 Tan J, Hytiroglou P, Wieczorek R, Park YN, Thung SN, Arias B, Theise ND. Immunohistochemical evidence for hepatic progenitor cells in liver diseases. Liver 2002;22:365-73.

96 Roskams T, Yang SQ, Koteish A, Durnez A, DeVos R, Huang X, Achten R, et al. Oxidative stress and oval cell accumulation in mice and humans with alcoholic and nonalcoholic fatty liver disease. Am J Pathol 2003;163:1301-11.

97 Evarts RP, Nagy P, Marsden E, Thorgeirsson SS. A precursor-product relationship exists between oval cells and hepatocytes in rat liver. Carcinogenesis 1987;8:1737-40.

98 Evarts RP, Nagy P, Nakatsukasa H, Marsden E, Thorgeirsson SS. In vivo differentiation of rat liver oval cells into hepatocytes. Cancer Res 1989;49:1541-7.

99 Yamashita T, Wang XW. Cancer stem cells in the development of liver cancer. J Clin Invest 2013;123:1911-8.

100 Lee JS, Heo J, Libbrecht L, Chu IS, Kaposi-Novak P, Calvisi DF, Mikaelyan A, et al. A novel prognostic subtype of human hepatocellular carcinoma derived from hepatic progenitor cells. Nat Med 2006;12:410-6.

101 Roskams T. Liver stem cells and their implication in hepatocellular and cholangiocarcinoma. Oncogene 2006;25:3818-22.

102 Yamashita T, Budhu A, Forgues M, Wang XW. Activation of hepatic stem cell marker EpCAM by Wnt-beta-catenin signaling in hepatocellular carcinoma. Cancer Res 2007;67:10831-9.

103 Ma S, Chan KW, Hu L, Lee TK, Wo JY, Ng IO, Zheng BJ, et al. Identification and characterization of tumorigenic liver cancer stem/progenitor cells. Gastroenterology 2007; 132:2542-56.

104 Sell S, Leffert HL. Liver cancer stem cells. J Clin Oncol 2008;26:2800-5. 
105 Yamashita T, Ji J, Budhu A, Forgues M, Yang W, Wang HY, Jia H, et al. EpCAMpositive hepatocellular carcinoma cells are tumor-initiating cells with stem/progenitor cell features. Gastroenterology 2009;136:1012-24.

106 Maetzel D, Denzel S, Mack B, Canis M, Went P, Benk M, Kieu C, et al. Nuclear signalling by tumour-associated antigen EpCAM. Nat Cell Biol 2009;11:162-71.

107 Jelnes P, Santoni-Rugiu E, Rasmussen M, Friis SL, Nielsen JH, Tygstrup N, Bisgaard HC. Remarkable heterogeneity displayed by oval cells in rat and mouse models of stem cell-mediated liver regeneration. Hepatology 2007;45:1462-70.

108 Boulter L, Govaere O, Bird TG, Radulescu S, Ramachandran P, Pellicoro A, Ridgway RA, et al. Macrophage-derived Wnt opposes Notch signaling to specify hepatic progenitor cell fate in chronic liver disease. Nat Med 2012;18:572-9.

$109 \mathrm{Hu}$ M, Kurobe M, Jeong YJ, Fuerer C, Ghole S, Nusse R, Sylvester KG. Wnt/betacatenin signaling in murine hepatic transit amplifying progenitor cells. Gastroenterology 2007;133:1579-91.

110 Itoh T, Kamiya Y, Okabe M, Tanaka M, Miyajima A. Inducible expression of Wnt genes during adult hepatic stem/progenitor cell response. FEBS Lett 2009;583:777-81.

111 Spee B, Carpino G, Schotanus BA, Katoonizadeh A, Vander Borght S, Gaudio E, Roskams T. Characterisation of the liver progenitor cell niche in liver diseases: potential involvement of Wnt and Notch signalling. Gut 2010;59:247-57.

112 Kodama Y, Hijikata M, Kageyama R, Shimotohno K, Chiba T. The role of notch signaling in the development of intrahepatic bile ducts. Gastroenterology 2004;127:177586.

113 Tchorz JS, Kinter J, Muller M, Tornillo L, Heim MH, Bettler B. Notch2 signaling promotes biliary epithelial cell fate specification and tubulogenesis during bile duct development in mice. Hepatology 2009;50:871-9.

114 Zong Y, Panikkar A, Xu J, Antoniou A, Raynaud P, Lemaigre F, Stanger BZ. Notch signaling controls liver development by regulating biliary differentiation. Development 2009;136:1727-39.

115 Jeliazkova P, Jors S, Lee M, Zimber-Strobl U, Ferrer J, Schmid RM, Siveke JT, et al. Canonical Notch2 signaling determines biliary cell fates of embryonic hepatoblasts and adult hepatocytes independent of Hes1. Hepatology 2013;57:2469-79. 
116 Fiorotto R, Raizner A, Morell CM, Torsello B, Scirpo R, Fabris L, Spirli C, et al. Notch signaling regulates tubular morphogenesis during repair from biliary damage in mice. J Hepatol 2013;59:124-30.

117 Fabris L, Cadamuro M, Guido M, Spirli C, Fiorotto R, Colledan M, Torre G, et al. Analysis of liver repair mechanisms in Alagille syndrome and biliary atresia reveals a role for notch signaling. Am J Pathol 2007;171:641-53.

118 Li L, Krantz ID, Deng Y, Genin A, Banta AB, Collins CC, Qi M, et al. Alagille syndrome is caused by mutations in human Jagged1, which encodes a ligand for Notch1. Nat Genet 1997;16:243-51.

119 Oda T, Elkahloun AG, Pike BL, Okajima K, Krantz ID, Genin A, Piccoli DA, et al. Mutations in the human Jagged1 gene are responsible for Alagille syndrome. Nat Genet 1997;16:235-42.

120 Osterreicher $\mathrm{CH}$, Trauner M. Animal models of biliary tract injury. Curr Opin Gastroenterol 2012;28:239-43.

121 Popov Y, Patsenker E, Fickert P, Trauner M, Schuppan D. Mdr2 (Abcb4)-/- mice spontaneously develop severe biliary fibrosis via massive dysregulation of pro- and antifibrogenic genes. J Hepatol 2005;43:1045-54.

122 Fickert P, Wagner M, Marschall HU, Fuchsbichler A, Zollner G, Tsybrovskyy O, Zatloukal K, et al. 24-norUrsodeoxycholic acid is superior to ursodeoxycholic acid in the treatment of sclerosing cholangitis in Mdr2 (Abcb4) knockout mice. Gastroenterology 2006;130:465-81.

123 Preisegger KH, Factor VM, Fuchsbichler A, Stumptner C, Denk H, Thorgeirsson SS. Atypical ductular proliferation and its inhibition by transforming growth factor beta1 in the 3,5-diethoxycarbonyl-1,4-dihydrocollidine mouse model for chronic alcoholic liver disease. Lab Invest 1999;79:103-9.

124 Fickert P, Stoger U, Fuchsbichler A, Moustafa T, Marschall HU, Weiglein AH, Tsybrovskyy $\mathrm{O}$, et al. A new xenobiotic-induced mouse model of sclerosing cholangitis and biliary fibrosis. Am J Pathol 2007;171:525-36.

125 Wang R, Lam P, Liu L, Forrest D, Yousef IM, Mignault D, Phillips MJ, et al. Severe cholestasis induced by cholic acid feeding in knockout mice of sister of Pglycoprotein. Hepatology 2003;38:1489-99. 
126 Fickert P, Fuchsbichler A, Wagner M, Silbert D, Zatloukal K, Denk H, Trauner M. The role of the hepatocyte cytokeratin network in bile formation and resistance to bile acid challenge and cholestasis in mice. Hepatology 2009;50:893-9.

127 Georgiev P, Jochum W, Heinrich S, Jang JH, Nocito A, Dahm F, Clavien PA. Characterization of time-related changes after experimental bile duct ligation. Br J Surg 2008;95:646-56.

128 Plum W, Tschaharganeh DF, Kroy DC, Corsten E, Erschfeld S, Dierssen U, Wasmuth $\mathrm{H}$, et al. Lack of glycoprotein 130/signal transducer and activator of transcription 3-mediated signaling in hepatocytes enhances chronic liver injury and fibrosis progression in a model of sclerosing cholangitis. Am J Pathol 2010;176:2236-46.

129 Marzioni M, Saccomanno S, Agostinelli L, Rychlicki C, De Minicis S, Pierantonelli I, Trauner M, et al. PDX-1/Hes-1 interactions determine cholangiocyte proliferative response to injury in rodents: possible implications for sclerosing cholangitis. J Hepatol 2013;58:750-6.

130 Petersen BE, Grossbard B, Hatch H, Pi L, Deng J, Scott EW. Mouse A6-positive hepatic oval cells also express several hematopoietic stem cell markers. Hepatology 2003;37:632-40.

131 Ishikawa T, Factor VM, Marquardt JU, Raggi C, Seo D, Kitade M, Conner EA, et al. Hepatocyte growth factor/c-met signaling is required for stem-cell-mediated liver regeneration in mice. Hepatology 2012;55:1215-26.

132 Wang C, Yang W, Yan HX, Luo T, Zhang J, Tang L, Wu FQ, et al. Hepatitis B virus $\mathrm{X}(\mathrm{HBx})$ induces tumorigenicity of hepatic progenitor cells in 3,5-diethoxycarbonyl1,4-dihydrocollidine-treated HBx transgenic mice. Hepatology 2012;55:108-20.

133 Rust C, Wild N, Bernt C, Vennegeerts T, Wimmer R, Beuers U. Bile acid-induced apoptosis in hepatocytes is caspase-6-dependent. J Biol Chem 2009;284:2908-16.

134 Harty MW, Papa EF, Huddleston HM, Young E, Nazareth S, Riley CA, Ramm GA, et al. Hepatic macrophages promote the neutrophil-dependent resolution of fibrosis in repairing cholestatic rat livers. Surgery 2008;143:667-78.

135 Levy R, Schlaeffer F, Keynan A, Nagauker O, Yaari A, Sikuler E. Increased neutrophil function induced by bile duct ligation in a rat model. Hepatology 1993;17:90814.

136 Kolios G, Valatas V, Kouroumalis E. Role of Kupffer cells in the pathogenesis of liver disease. World J Gastroenterol 2006;12:7413-20. 
137 Moazzam FN, Brems JJ, Yong SL, Filkins JP, Fisher SG, Holt DR, Gamelli RL, et al. Endotoxin potentiates hepatocyte apoptosis in cholestasis. J Am Coll Surg 2002;194:731-9.

138 Malhi H, Gores GJ. Cellular and molecular mechanisms of liver injury. Gastroenterology 2008;134:1641-54.

139 Zollner G, Trauner M. Nuclear receptors as therapeutic targets in cholestatic liver diseases. Br J Pharmacol 2009;156:7-27.

140 Steiner JW, Carruthers JS, Kalifat SR. Vascular alterations in the liver of rats with extrahepatic biliary obstruction. An electron and fluorescent microscopic study. Exp Mol Pathol 1962;1:427-56.

141 Aube C, Moal F, Oberti F, Roux J, Croquet V, Gallois Y, Argaud C, et al. Diagnosis and measurement of liver fibrosis by MRI in bile duct ligated rats. Dig Dis Sci 2007;52:2601-9.

142 Ruddell RG, Knight B, Tirnitz-Parker JE, Akhurst B, Summerville L, Subramaniam VN, Olynyk JK, et al. Lymphotoxin-beta receptor signaling regulates hepatic stellate cell function and wound healing in a murine model of chronic liver injury. Hepatology 2009;49:227-39.

143 Iredale J. Defining therapeutic targets for liver fibrosis: exploiting the biology of inflammation and repair. Pharmacol Res 2008;58:129-36.

144 Liedtke C, Luedde T, Sauerbruch T, Scholten D, Streetz K, Tacke F, Tolba R, et al. Experimental liver fibrosis research: update on animal models, legal issues and translational aspects. Fibrogenesis Tissue Repair 2013;6:19.

145 Slott PA, Liu MH, Tavoloni N. Origin, pattern, and mechanism of bile duct proliferation following biliary obstruction in the rat. Gastroenterology 1990;99:466-77.

146 Schefe JH, Lehmann KE, Buschmann IR, Unger T, Funke-Kaiser H. Quantitative real-time RT-PCR data analysis: current concepts and the novel "gene expression's CT difference" formula. J Mol Med (Berl) 2006;84:901-10.

147 Hanada S, Snider NT, Brunt EM, Hollenberg PF, Omary MB. Gender dimorphic formation of mouse Mallory-Denk bodies and the role of xenobiotic metabolism and oxidative stress. Gastroenterology 2010;138:1607-17.

148 Xia JL, Dai C, Michalopoulos GK, Liu Y. Hepatocyte growth factor attenuates liver fibrosis induced by bile duct ligation. Am J Pathol 2006;168:1500-12. 
149 Strnad P, Tao GZ, Zhou Q, Harada M, Toivola DM, Brunt EM, Omary MB. Keratin mutation predisposes to mouse liver fibrosis and unmasks differential effects of the carbon tetrachloride and thioacetamide models. Gastroenterology 2008;134:1169-79.

150 Irizarry RA, Hobbs B, Collin F, Beazer-Barclay YD, Antonellis KJ, Scherf U, Speed TP. Exploration, normalization, and summaries of high density oligonucleotide array probe level data. Biostatistics 2003;4:249-64.

151 Zeeberg BR, Feng W, Wang G, Wang MD, Fojo AT, Sunshine M, Narasimhan S, et al. GoMiner: a resource for biological interpretation of genomic and proteomic data. Genome Biol 2003;4:R28.

152 Molnar A, Haybaeck J, Lackner C, Strnad P. The cytoskeleton in nonalcoholic steatohepatitis: 100 years old but still youthful. Expert Rev Gastroenterol Hepatol 2011;5:167-77.

153 Beale EG, Harvey BJ, Forest C. PCK1 and PCK2 as candidate diabetes and obesity genes. Cell Biochem Biophys 2007;48:89-95.

154 Gomez-Valades AG, Mendez-Lucas A, Vidal-Alabro A, Blasco FX, Chillon M, Bartrons R, Bermudez J, et al. Pck1 gene silencing in the liver improves glycemia control, insulin sensitivity, and dyslipidemia in db/db mice. Diabetes 2008;57:2199-210.

155 Millward CA, Desantis D, Hsieh CW, Heaney JD, Pisano S, Olswang Y, Reshef L, et al. Phosphoenolpyruvate carboxykinase (Pck1) helps regulate the triglyceride/fatty acid cycle and development of insulin resistance in mice. J Lipid Res 2010;51:1452-63.

156 Lin J, Handschin C, Spiegelman BM. Metabolic control through the PGC-1 family of transcription coactivators. Cell Metab 2005;1:361-70.

157 Liu C, Li S, Liu T, Borjigin J, Lin JD. Transcriptional coactivator PGC-1alpha integrates the mammalian clock and energy metabolism. Nature 2007;447:477-81.

158 Sahin E, Colla S, Liesa M, Moslehi J, Muller FL, Guo M, Cooper M, et al. Telomere dysfunction induces metabolic and mitochondrial compromise. Nature 2011;470:359-65.

159 Iida M, Sasaki T, Komatani H. Overexpression of Plk3 causes morphological change and cell growth suppression in Ras pathway-activated cells. J Biochem 2009;146:501-7.

160 Trauner M, Wagner M, Fickert P, Zollner G. Molecular regulation of hepatobiliary transport systems: clinical implications for understanding and treating cholestasis. J Clin Gastroenterol 2005;39:S111-24. 
161 Wagner M, Halilbasic E, Marschall HU, Zollner G, Fickert P, Langner C, Zatloukal $\mathrm{K}$, et al. CAR and PXR agonists stimulate hepatic bile acid and bilirubin detoxification and elimination pathways in mice. Hepatology 2005;42:420-30.

162 Gong AY, Tietz PS, Muff MA, Splinter PL, Huebert RC, Strowski MZ, Chen XM, et al. Somatostatin stimulates ductal bile absorption and inhibits ductal bile secretion in mice via SSTR2 on cholangiocytes. Am J Physiol Cell Physiol 2003;284:C1205-14.

163 D'Adamo MC, Shang L, Imbrici P, Brown SD, Pessia M, Tucker SJ. Genetic inactivation of Kcnj16 identifies Kir5.1 as an important determinant of neuronal PCO2/pH sensitivity. J Biol Chem 2011;286:192-8.

164 Paulais M, Bloch-Faure M, Picard N, Jacques T, Ramakrishnan SK, Keck M, Sohet F, et al. Renal phenotype in mice lacking the Kir5.1 (Kcnj16) K+ channel subunit contrasts with that observed in SeSAME/EAST syndrome. Proc Natl Acad Sci U S A 2011;108:10361-6.

165 Wilhelmsson U, Faiz M, de Pablo Y, Sjoqvist M, Andersson D, Widestrand A, Potokar M, et al. Astrocytes negatively regulate neurogenesis through the Jagged1mediated Notch pathway. Stem Cells 2012;30:2320-9.

166 Sandilands A, Smith FJ, Lunny DP, Campbell LE, Davidson KM, MacCallum SF, Corden LD, et al. Generation and characterisation of keratin 7 (K7) knockout mice. PLoS One 2013;8:e64404.

167 Haybaeck J, Stumptner C, Thueringer A, Kolbe T, Magin TM, Hesse M, Fickert P, et al. Genetic background effects of keratin 8 and 18 in a DDC-induced hepatotoxicity and Mallory-Denk body formation mouse model. Lab Invest 2012;92:857-67.

168 Toivola DM, Nieminen MI, Hesse M, He T, Baribault H, Magin TM, Omary MB, et al. Disturbances in hepatic cell-cycle regulation in mice with assembly-deficient keratins 8/18. Hepatology 2001;34:1174-83.

169 Tao GZ, Toivola DM, Zhong B, Michie SA, Resurreccion EZ, Tamai Y, Taketo MM, et al. Keratin-8 null mice have different gallbladder and liver susceptibility to lithogenic diet-induced injury. J Cell Sci 2003;116:4629-38.

170 Toivola DM, Baribault H, Magin T, Michie SA, Omary MB. Simple epithelial keratins are dispensable for cytoprotection in two pancreatitis models. Am J Physiol Gastrointest Liver Physiol 2000;279:G1343-54. 
171 Ameen NA, Figueroa Y, Salas PJ. Anomalous apical plasma membrane phenotype in CK8-deficient mice indicates a novel role for intermediate filaments in the polarization of simple epithelia. J Cell Sci 2001;114:563-75.

172 Oriolo AS, Wald FA, Ramsauer VP, Salas PJ. Intermediate filaments: a role in epithelial polarity. Exp Cell Res 2007;313:2255-64.

173 Tietz PS, Marinelli RA, Chen XM, Huang B, Cohn J, Kole J, McNiven MA, et al. Agonist-induced coordinated trafficking of functionally related transport proteins for water and ions in cholangiocytes. J Biol Chem 2003;278:20413-9.

174 Warnes TW. Alkaline phosphatase. Gut 1972;13:926-37.

175 Wolf PL. Clinical significance of an increased or decreased serum alkaline phosphatase level. Arch Pathol Lab Med 1978;102:497-501.

176 Stremmel W, Tavoloni N, Berk PD. Uptake of bilirubin by the liver. Semin Liver Dis 1983;3:1-10.

177 Horvath T, Past T, Par A, Kadas I, Javor T. Sulfadimidine kinetics in patients with various chronic liver diseases. Pol J Pharmacol Pharm 1988;40:257-64.

178 Chapman WC, Halevy A, Blumgart LH, Benjamin IS. Postcholecystectomy bile duct strictures. Management and outcome in 130 patients. Arch Surg 1995;130:597-602; discussion -4 .

179 de Caestecker JS, Jazrawi RP, Nisbett JA, Joseph AE, Maxwell JD, Northfield TC. Direct assessment of the mechanism for a raised serum bile acid level in chronic liver disease. Eur J Gastroenterol Hepatol 1995;7:955-61.

180 Parraga ME, Kaneko JJ. Total serum bile acids and the bile acid profile as tests of liver function. Vet Res Commun 1985;9:79-88.

181 Loranger A, Duclos S, Grenier A, Price J, Wilson-Heiner M, Baribault H, Marceau N. Simple epithelium keratins are required for maintenance of hepatocyte integrity. Am $\mathbf{J}$ Pathol 1997;151:1673-83.

182 Concepcion AR, Lopez M, Ardura-Fabregat A, Medina JF. Role of AE2 for $\mathrm{pH}$ regulation in biliary epithelial cells. Front Physiol 2013;4:413.

$183 \mathrm{Ku} \mathrm{NO}$, Soetikno RM, Omary MB. Keratin mutation in transgenic mice predisposes to Fas but not TNF-induced apoptosis and massive liver injury. Hepatology 2003;37:1006-14. 
184 Habtezion A, Toivola DM, Asghar MN, Kronmal GS, Brooks JD, Butcher EC, Omary MB. Absence of keratin 8 confers a paradoxical microflora-dependent resistance to apoptosis in the colon. Proc Natl Acad Sci U S A 2011;108:1445-50.

$185 \mathrm{Ku}$ NO, Toivola DM, Strnad P, Omary MB. Cytoskeletal keratin glycosylation protects epithelial tissue from injury. Nat Cell Biol 2010;12:876-85.

186 Noshiro H, Hotokezaka M, Higashijima H, Iwamoto T, Nakahara S, Mibu R, Soloway RD, et al. Gallstone formation and gallbladder bile composition after colectomy in dogs. Dig Dis Sci 1996;41:2423-32.

187 Chen CY, Shiesh SC, Lin XZ. Biliary sludge and pigment stone formation in bile duct-ligated guinea pigs. Dig Dis Sci 1999;44:203-9.

188 Soloway RD, Trotman BW, Ostrow JD. Pigment gallstones. Gastroenterology 1977;72:167-82.

189 Depianto D, Kerns ML, Dlugosz AA, Coulombe PA. Keratin 17 promotes epithelial proliferation and tumor growth by polarizing the immune response in skin. Nat Genet 2010;42:910-4.

190 Alam H, Sehgal L, Kundu ST, Dalal SN, Vaidya MM. Novel function of keratins 5 and 14 in proliferation and differentiation of stratified epithelial cells. Mol Biol Cell 2011;22:4068-78.

191 Kim H, Yoo JE, Cho JY, Oh BK, Yoon YS, Han HS, Lee HS, et al. Telomere length, TERT and shelterin complex proteins in hepatocellular carcinomas expressing "stemness"-related markers. J Hepatol 2013;59:746-52.

192 Crosby HA, Hubscher S, Fabris L, Joplin R, Sell S, Kelly D, Strain AJ. Immunolocalization of putative human liver progenitor cells in livers from patients with end-stage primary biliary cirrhosis and sclerosing cholangitis using the monoclonal antibody OV-6. Am J Pathol 1998;152:771-9.

193 Matthews VB, Klinken E, Yeoh GC. Direct effects of interleukin-6 on liver progenitor oval cells in culture. Wound Repair Regen 2004;12:650-6.

194 Hyder CL, Isoniemi KO, Torvaldson ES, Eriksson JE. Insights into intermediate filament regulation from development to ageing. J Cell Sci 2011;124:1363-72.

195 Hirschfield GM, Gershwin ME. The immunobiology and pathophysiology of primary biliary cirrhosis. Annu Rev Pathol 2013;8:303-30.

196 Knight B, Akhurst B, Matthews VB, Ruddell RG, Ramm GA, Abraham LJ, Olynyk $\mathrm{JK}$, et al. Attenuated liver progenitor (oval) cell and fibrogenic responses to the choline 
deficient, ethionine supplemented diet in the BALB/c inbred strain of mice. J Hepatol 2007;46:134-41.

197 Jakubowski A, Ambrose C, Parr M, Lincecum JM, Wang MZ, Zheng TS, Browning B, et al. TWEAK induces liver progenitor cell proliferation. J Clin Invest 2005;115:2330-40.

198 Tirnitz-Parker JE, Viebahn CS, Jakubowski A, Klopcic BR, Olynyk JK, Yeoh GC, Knight B. Tumor necrosis factor-like weak inducer of apoptosis is a mitogen for liver progenitor cells. Hepatology 2010;52:291-302.

199 Kuramitsu K, Sverdlov DY, Liu SB, Csizmadia E, Burkly L, Schuppan D, Hanto DW, et al. Failure of fibrotic liver regeneration in mice is linked to a severe fibrogenic response driven by hepatic progenitor cell activation. Am J Pathol 2013;183:182-94.

200 Strnad P, Lienau TC, Tao GZ, Lazzeroni LC, Stickel F, Schuppan D, Omary MB. Keratin variants associate with progression of fibrosis during chronic hepatitis $\mathrm{C}$ infection. Hepatology 2006;43:1354-63.

201 Strnad P, Kucukoglu O, Lunova M, Guldiken N, Lienau TC, Stickel F, Omary MB. Non-coding keratin variants associate with liver fibrosis progression in patients with hemochromatosis. PLoS One 2012;7:e32669.

202 Scholten D, Osterreicher CH, Scholten A, Iwaisako K, Gu G, Brenner DA, Kisseleva T. Genetic labeling does not detect epithelial-to-mesenchymal transition of cholangiocytes in liver fibrosis in mice. Gastroenterology 2010;139:987-98. 


\section{Appendix}

\subsection{List of tables}

Table 1. Classification and localization of intermediate filament (IF) proteins.............1

Table 2. Distributions of keratins in epithelial tissues...............................2

Table 3. Representative human disorders related with keratin mutations.................. 3

Table 4. Common cholestatic disorders from human patients.........................

Table 5. Major bile-related transporters in hepatocytes.............................. 8

Table 6. Major bile-related transporters in cholangiocytes........................... 8

Table 7. List of general experimental equipments.................................. 14

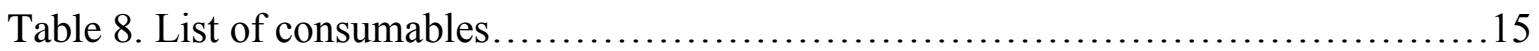

Table 9. List of commercial kits, enzymes and solutions............................ 16

Table 10. List of chemicals...................................................... 17

Table 11. List of experimental buffers/solutions..................................20

Table 12. List of oligonucleotides for quantitative RT-PCR .........................22

Table 13. List of oligonucleotides for K19 genotyping ................................ 22

Table 14. List of primary antibodies for experiments.............................. 23

Table 15. List of secondary antibodies for Western blotting..........................23

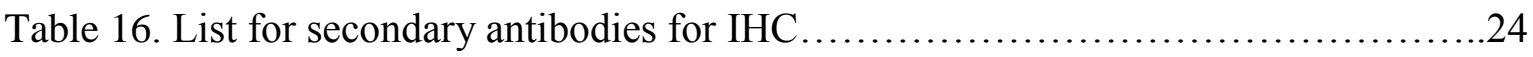

Table 17. List for secondary antibodies for IF ..................................... 24

Table 18. PCR mix system with $30 \mu \mathrm{l}$ for each sample..............................25

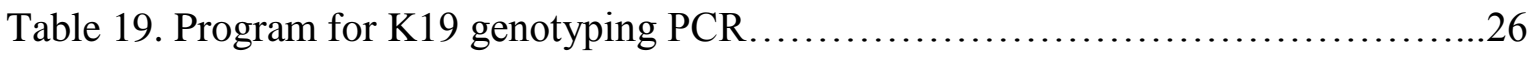

Table 20. Program for quantitative real-time PCR ................................... 30

Table 21. Composition of $10 \%$ acrylamide gels.................................. 33

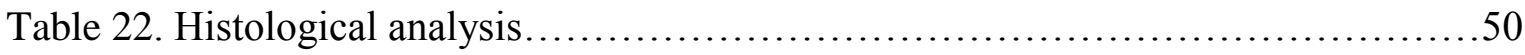

Table 23. Selected differential expressed genes in mice chronically fed with DDC........52

Table 24. Morphometric analysis of DDC-treated mice...............................55 


\subsection{List of figures:}

Figure 1. Schematic morphology of biliary structures...............................

Figure 2. Different types of ductular proliferation in regenerating livers................ 11

Figure 3. Confirmation of keratin 19 knockout (K19-KO) genotyping at protein level.....44

Figure 4. Keratin expression in digestive epithelia. .45

Figure 5. Immunofluorescence (IF) staining of keratin $(\mathrm{K}) 7$ and $\mathrm{K} 8$ in untreated livers...46

Figrue 6. Quantification of keratin distribution....

Figure 7. Bile flow quantification in untreated keratin 19 knockout (K19-KO) and wildtype (WT) mice.

Figure 8. Output of major bile constituents in keratin 19 knockout (K19-KO) and wildtype

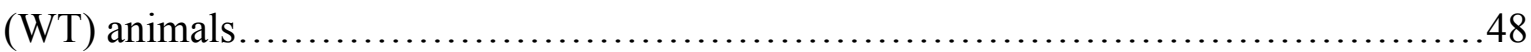

Figure 9. Serum biochemical analysis of control (CTL) and DDC-treated animals........49

Figure 10. H\&E staining of 4w-DDC-fed (DDC) livers............................. 50

Figure 11. Porphyrin levels in 4 weeks DDC-fed livers...............................51

Figure 12. cDNA microarray of DDC-fed livers....................................52

Figure 13. Somastatin receptor type 2 (Sstr2) levels in keratin 19-wildtype (WT) and

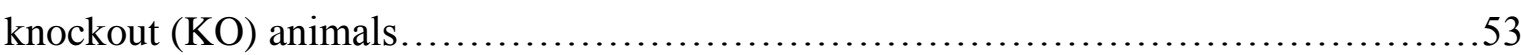

Figure 14. Hematoxylin and eosin (H\&E) staining of control (CTL) and 4w-DDC-fed (DDC) livers...

Figure 15. Immunofluorescence (IF) staining of pankeratin (panK) from control (CTL) and

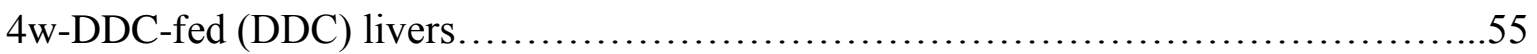

Figure 16. Immunohistochemistry (IHC) staining of Ki67 in control (CTL) and 4w-DDC-

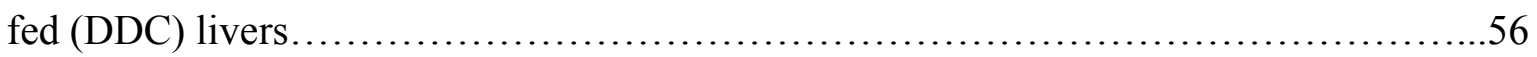

Figure 17. Immunohistochemistry (IHC) staining of D237 epitope in control (CTL) and

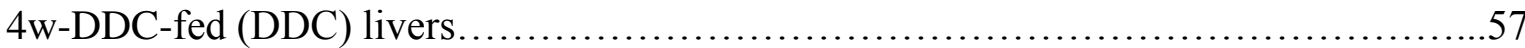

Figure 18. Double immunofluorescence (IF) staining for pankeratin (panK) and A6 in control (CTL) and 4w-DDC-fed (DDC) livers..................................... 58

Figure 19. Double immunofluorescence (IF) staining for pankeratin (panK) and Notch2 in

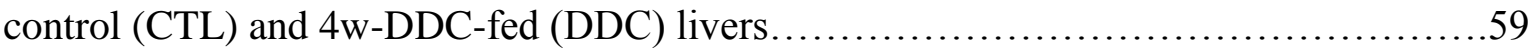


Figure 20. Sirius red staining of control (CTL) and 4w-DDC-fed (DDC) livers .60

Figure 21. Quantitative real-time RT-PCR for alpha-1 type 1 collagen (Colla1) gene in control (CTL) and 4w-DDC-fed (DDC) livers...................................61

Figure 22. Hepatic hydroxyproline assay.....................................6 61

Figure 23. Hematoxylin and eosin (H\&E) staining from control (CTL) and common bile

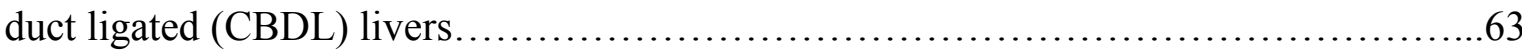

Figure 24. Sirius red staining of control (CTL) and common bile duct ligated (CBDL) livers

Figure 25. Serum biochemical analysis of control (CTL) mice and animals 5 days after common bile duct ligation (5d-BDL)....

Figure 26. Serum biochemical analysis of control (CTL) animals and mice 21 days after

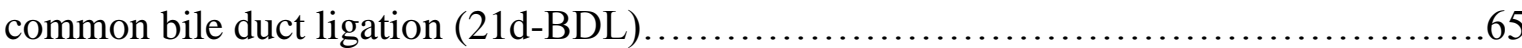

Figure 27. Schematic figure of pathological difference between keratin 19 wildtype (K19$\mathrm{WT})$ and knockout (KO) mice. 


\section{Acknowledgements}

At this moment I can convince myself that my doctoral thesis will go to the end. When I look back the whole process, so many people have been helping and supporting me. Thank you very much!

First of all, I must express my gratitude to my supervisor, PD Dr. Pavel Strnad, for providing me the opportunity to pursue my doctoral study in Germany. It is my great pleasure to join your group, and I benefited quite a lot from your outstanding supervision and encouraging support all through the research project. I learned how to be one resourceful and hardworking scientist, and you definitely are my role model.

Next, I would like to thank my colleagues who helped me at all times. They are Nurdan, Elke, Peggy, Manuela, Özlem, Mariia, Kateryna, Katrin, Claudia, Tina, Suzanne, Anke, Renwar, and Valentyn from Universitätsklinikum Ulm; and Annika, Deniz, Linda, Ingrid from Uniklinik Aachen. Because of you, I overcame the formidable cultural differences quickly and felt at home during my PhD study. Without your help and patience, I cannot complete my study at all.

I also want to thank my family (especially my grandparents Mr. Di Chen and Mrs. Fan Song) for their unconditional support and encouragement. It is your patience that let me choose my way independently; it is your trust that guide me conquering all the obstacles; it is your love that aid me confidence to move forward. This thesis is dedicated to you. 


\section{Curriculum vitae}

\section{Personal Data}

Name

Yu Chen

Date/place of birth

16.01.1983, Jinan, China

Nationality

Chinese

\section{Education}

10/2009- present

Universitätsklinikum Ulm, Germany

Innere Medizin I

Major: Human Biology

Degree: $\mathrm{PhD}$ to be expected

09/2005- 07/2008

Shandong Academy of Medical Sciences, Jinan, China

Shandong Medicinal Biotechnology centre

Major: Microbiology and Biochemical Pharmacy

Degree: Master of Medicine

09/2001- 07/2005

Shandong Normal University, Jinan, China

College of Life Science

Major: Biological Sciences

Degree: Bachelor of Science

\section{Research experience}

01/2013- present

Uniklinik Aachen, Germany

Medizinische klinik III

Projects: (1) The role of keratin 19 in liver progenitor cell (LPC) activation; (2) The pathogenesis of nonalcoholic steatohepatitis (NASH). 
Innere Medizin I

Projects: (1) The role of keratin 19 in biliary system; (2) The pathogenesis of Mallory-Denk Body (MDB) formation.

07/2008- 09/2009

Shandong Academy of Medical Sciences, Jinan, China

Shandong Medicinal Biotechnology centre

Projects: (1) The pathogenesis of Rheumatoid Arthritis with genomic and proteomic methods; (2) The relationship between Rheumatoid Arthritis and tumour with genomic and proteomic methods

09/2005- 06/2008

Shandong Academy of Medical Sciences, Jinan, China Shandong Medicinal Biotechnology centre

Projects: Investigation of biomarker for early diagnosis of pancreatic cancer markers using proteomic methods

03/2005- 06/2005

Shandong Normal University, Jinan, China

College of Life Science

Projects: Investigation of the optimum temperature for the apoptosis of tomato leaves under the heating stress

\section{Publications}

1. Cui Y, Tian M, Zong M, Teng M, Chen Y, Lu J, Jiang J, Liu X, Han J, et al. Proteomic analysis of pancreatic ductal adenocarcinoma compared with normal adjacent pancreatic tissue and pancreatic benign cystadenoma. Pancreatology. 2009;9(1-2): 89-98.

2. Chang X, Cui Y, Zong M, Zhao Y, Yan X, Chen Y, Han J, et al. identification of proteins with increased expression in rheumatoid arthritis synovial tissues. J Rheumatol. 2009 May;36(5):872-80. 
3. Chang X, Zhao Y, Wang Y, Chen Y, Yan X. Screening citrullinated proteins in synovial tissues of rheumatoid arthritis using 2-dimentional western blotting. J Rheumatol. 2013 Mar;40(3):219-27.

4. Ozlem K, Guldiken N, Chen Y, Usachov V, El-Heliebi A, Haybaeck J, Denk H, Trautwein C, Strnad P. High-fat diet triggers Mallory-Denk body formation via misfolding and crosslinking of excess keratin 8. Hepatology. 2014 Feb 12

5. Lunova M, Goehring C, Kuscuoglu D, Mueller K, Chen Y, Walther P, Deschemin JC, Vaulont S, Haybaeck J, Lackner C, Trautwein C, Strnad P. Hepcidin knockout mice fed with iron-rich diet develop chronic liver injury and liver fibrosis due to lysosomal iron overload. Journal of Hepatology. 2014 May 6

\section{Academic honor}

- 2014 Young Investigator Bursary (Registration Busary), International Liver Congress 2014 by EASL, London, UK, April 9-13, 2014

- 2012 Young Investigator Bursary (Full Bursary), International Liver Congress 2012 by EASL, Barcelona, Spain, April 18-22, 2012

- 2011 Trainee support (Maurice E. Müller Foundation), $7^{\text {th }}$ European Conference on Intermediate Filaments in Health and Disease, Mykonos, Greece, June $16^{\text {th }} 19^{\text {th }}, 2011$

- The prize of 2008 postgraduate science and technology achievements awards of Shandong Province (No. 2008YJS090) 